\title{
Evolutionary relationships, biogeography and morphological characters of Glinus (Molluginaceae), with special emphasis on the genus composition in Sub-Saharan Africa
}

\author{
Alexander P. Sukhorukov ${ }^{1,2}$, Alexander Sennikov ${ }^{3,4}$, Marie Claire Veranso-Libalah ${ }^{5}$, \\ Maria Kushunina $^{6}$, Maya V. Nilova', Roger Heath ${ }^{7,8}$, Alison Heath ${ }^{7,8}$, \\ Yuri Mazei', Maxim A. Zaika'
}

I Department of Higher Plants, Biological Faculty, Lomonosov Moscow State University, 119234, Moscow, Russia 2 Laboratory Herbarium (TK), Tomsk State University, Lenin Ave. 36, 634050, Tomsk, Russia 3 Botanical Museum, Finnish Museum of Natural History, P.O. Box 7, 00014 University of Helsinki, Finland 4 Herbarium, Komarov Botanical Institute of Russian Academy of Sciences, Prof. Popov St. 2, 197376 St. Petersburg, Russia 5 Institut für Molekulare Physiologie, Johannes Gutenberg-Universität Mainz, Germany 6 Department of Plant Physiology, Biological Faculty, Lomonosov Moscow State University, 119234, Moscow, Russia 7 University of Botswana, Plot 4775, Notwane Road, Gaborone, Botswana 8 Royal Botanic Gardens, Kew, Richmond, TW9 3AE, United Kingdom 9 Department of Hydrobiology, Biological Faculty, Lomonosov Moscow State University, 119234, Moscow, Russia

Corresponding author: Alexander P. Sukhorukov (suchor@mail.ru)

Academic editor: G.P. G. del Galdo | Received 22 November 2020 | Accepted 21 January 2021 | Published 22 February 2021

Citation: Sukhorukov AP, Sennikov A, Veranso-Libalah MC, Kushunina M, Nilova MV, Heath R, Heath A, Mazei Y, Zaika MA (2021) Evolutionary relationships, biogeography and morphological characters of Glinus (Molluginaceae), with special emphasis on the genus composition in Sub-Saharan Africa. PhytoKeys 173: 1-92. https://doi.org/10.3897/ phytokeys. 173.60898

\begin{abstract}
Glinus is a small genus of Molluginaceae with 8-10 species mostly distributed in the tropics of the World. Its composition and evolutionary relationships were poorly studied. A new molecular phylogeny constructed here using nuclear (ITS) and chloroplast $(r b c L, \operatorname{trn} K$-matK) markers confirmed the monophyly of the genus. Based on ITS analysis, the following well-supported lineages are present within Glinus: the $G$. bainesii lineage is recovered as sister to the remainder of the genus followed by G. oppositifolius. Three other clades are: $G$. hirtus with $G$. orygioides; $G$. radiatus and $G$. lotoides; the latter is represented by a sample from North America, and G. zambesiacus as sister to G. setiflorus + G. lotoides + G. dictamnoides. On the plastid gene tree, G. bainesii + G. oppositifolius form a sister clade to all other Glinus species. The next clade is formed by $G$. hirtus and G. orygioides followed by G. radiatus plus an American sample of
\end{abstract}

Copyright Alexander P. Sukhorukov et al. This is an open access article distributed under the terms of the Creative Commons Attribution License (CC BY 4.0), which permits unrestricted use, distribution, and reproduction in any medium, provided the original author and source are credited. 
G. lotoides. The next branch comprises G. setiflorus as sister to G. zambesiacus + G. lotoides + G. dictamnoides. Glinus seems to have originated from Africa around the Late Eocene or Early Miocene, with further radiations to Australia and the Americas during the Late Miocene or Late Pliocene. Compared with the previous limited character set used for the diagnostics, we have found ten new morphological and carpological traits distinguishing Glinus members. In both trees based on nuclear and plastid datasets, the major phylogenetic clades cannot be characterized by the peculiar morphological characters. Many shared character states leading to their contrasting pattern in the multivariate analysis model are interpreted as a high homoplasy in the phylogenetically distant species. We paid special attention to the composition of the genus in Sub-Saharan Africa, a region with the greatest species diversity. Our results provide new insight into the taxonomy of Glinus in this region. Glinus lotoides var. virens accepted in many previous works is a synonym of $G$. dictamnoides that is closely related to $G$. lotoides based on molecular analysis and morphological characters. The status of the American populations of $G$. lotoides needs further investigation due to different characters of the specimens from the Old and the New World. Many specimens previously identified as $G$. lotoides var. virens and as the intermediates $G$. lotoides $\times G$. oppositifolius belong to G. zambesiacus sp. nov. and G. hirtus comb. nov. ( $\equiv$ Mollugo hirta); the latter species is resurrected from synonymy after 200 years of unacceptance. In some African treatments, G. hirtus was known under the invalidly published name $G$. dahomensis. Glinus zambesiacus is distributed in the southern and eastern parts of tropical Africa, and G. hirtus previously assumed to be endemic to West Africa is indeed a species with a wide distribution across the tropical part of the continent. Glinus microphyllus previously accepted as endemic to West Tropical Africa together with other new synonyms (G. oppositifolius var. lanatus, $G$. herniarioides, Wycliffea rotundifolia) is considered here as G. oppositifolius var. keenanii comb. nov. (三Mollugo hirta var. keenanii), a variety found across the entire distribution of G. oppositifolius (Australia, Asia, and Africa). The presence of the American G. radiatus in Africa is not confirmed, and all records of this species belong to $G$. hirtus. The lectotypes of some names ( $G$. dictamnoides, G. herniarioides, Mollugo hirta, M. setiflora, Pharnaceum pentagynum, Wycliffea) as well as a neotype of G. trianthemoides are designated. A new key to the identification of all Glinus species in Sub-Saharan Africa is provided. A checklist is given of all accepted species in this region (G. bainesii, G. hirtus, G. lotoides, G. oppositifolius s.l., G. setiflorus, and $G$. zambesiacus) with their nomenclature, morphological description and geographical distribution.

\section{Keywords}

Biogeography, Glinus, Molluginaceae, molecular phylogeny, Sub-Saharan Africa, taxonomic revision

\section{Table of contents}

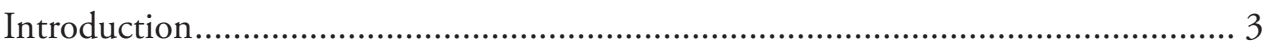

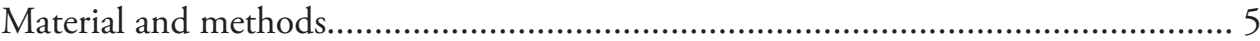

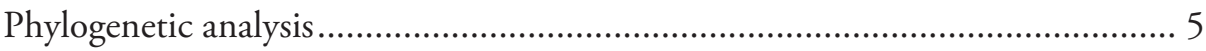

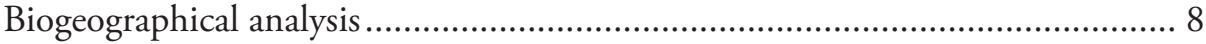

Multivariate analysis................................................................................ 8

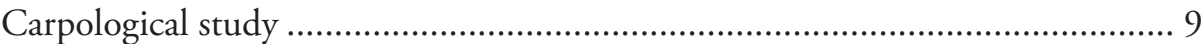

Choosing the territory for taxonomic study............................................... 10

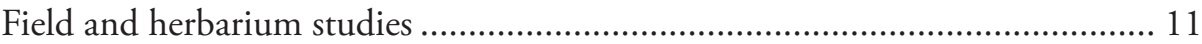

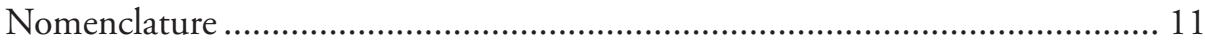

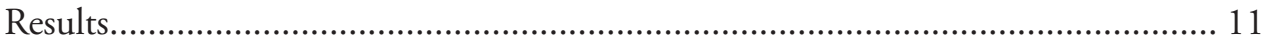




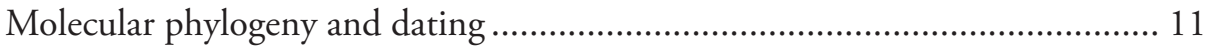

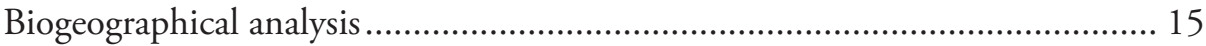

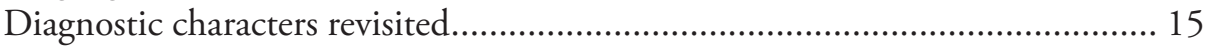

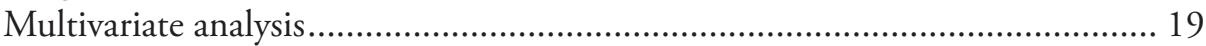

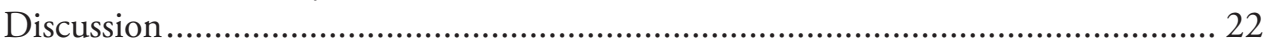

Morphological interpretation of the phylogenetic results................................. 22

Biogeography …........................................................................................ 24

Extant geographical distribution .................................................................. 24

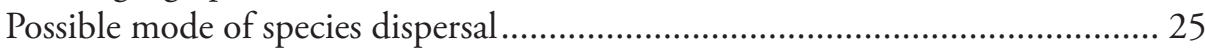

Taxonomic treatment of Glinus in Sub-Saharan Africa .................................... 26

Artificial key to the Glinus species in sub-Saharan Africa based on gross mor-

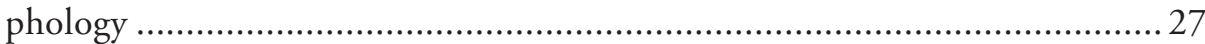

List of accepted species in Sub-Saharan Africa (arranged alphabetically) ........... 28

The most predictable records in the countries where no Glinus species were pre-

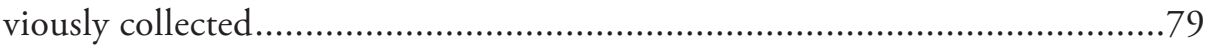

Records excluded from Sub-Saharan Africa ................................................. 79

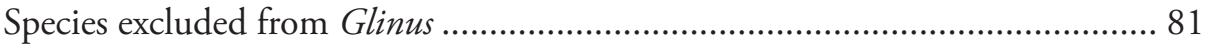

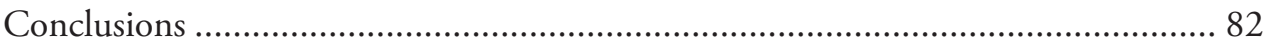

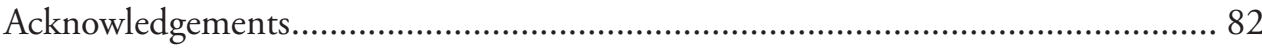

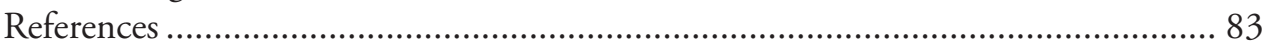

\section{Introduction}

Glinus L. comprises six to ten species distributed in the warm regions of the world (Backer 1951; Endress and Bittrich 1993; Thulin et al. 2016). It includes annual and perennial herbs and rarely subshrubs covered with simple or stellate hairs, with exstipulate, lanceolate to obovate leaves arranged in false whorls of 3-5, several to many verticillate, sessile or pedicellate flowers, pentamerous perianth consisting of free segments that are green dorsally and white, pink or yellow ventrally, petaloid staminodes often present originating from the outer stamen whorl, 3-30 stamens and 3- or 5-valvate, strongly hydrochastic capsules with numerous small arillate seeds. Among Caryophyllales as well as Molluginaceae, Glinus is characterized by the remarkable seed aril divided into two parts: a white, usually well-visible hood covering the funiculus and a large ribbon-like appendage (Pitot 1965; Narayana and Lodha 1972; Endress and Bittrich 1993; Sukhorukov et al. 2018). Molecular phylogenetic analyses based on four species (G. lotoides L., G. oppositifolius (L.) Aug.DC., G. radiatus (Ruiz \& Pav.) Rohrb. and G. setiflorus Forssk.) suggest the genus is monophyletic (Christin et al. 2011; Thulin et al. 2016).

Species delimitation within Glinus is usually based on the pubescence details (stellate vs. simple trichomes; presence of tiny prickles on stem and leaves), leaf dimensions and shape, number of flowers in the leaf axils, and number of stamens (e.g., Bogle 1970; Short 2002; Lu and Hartmann 2003; Vincent 2003). These character sets are 
sufficient for the delimitation of G. lotoides and G. oppositifolius, the most widespread species in the Old World (e.g., Hutchinson and Dalziel 1927; Backer 1951; Jeffrey 1961; Gonçalves 1978; Hargreaves 1995; Gilbert 2000; Short 2002; Retief and Meyer 2017). In some cases, seed size and ultrasculpture are useful tools for identification, e.g., in the characterization of G. setiflorus, G. orygioides F.Muell. and G. bainesii (Oliv.) Pax (Sukhorukov et al. 2018). Additional characters (pubescence density and pedicel length) were used for the infraspecific descriptions of the morphologically heterogeneous G. lotoides and G. oppositifolius (Gonçalves 1965, 1970, 1978). There was an attempt to divide Glinus into two subgeneric groups called Euglinus (三 Glinus) and Pseudoglinus Endl. mainly based on stellate vs. non-stellate pubescence (Endlicher 1840), but this classification was never used.

The members of the genus are unevenly distributed across the tropics and subtropics of the world with most species present in Africa. In total, seven Glinus species are currently accepted in all parts of the continent (Klopper et al. 2006; APD 2019). Glinus lotoides is present throughout Africa (Jeffrey 1961; Maire 1962; Gonçalves 1978; APD 2019). Glinus oppositifolius possesses a similarly wide distribution, but is not reported from North Africa (Maire 1962; Boulos 1999; Hassan et al. 2005). Other species are considered to be restricted to smaller regions. Glinus setiflorus is widespread in E and NE Africa (Jeffrey 1961; Gilbert 1993a, 2000). Glinus dahomensis A.Chev. and G. microphyllus Hauman are considered to be local endemics to different territories of West Africa (Chevalier 1938; Hauman 1949; Lebrun and Stork 2003). Another African species, G. bainesii is restricted to Botswana, Mozambique, Zimbabwe and the eastern part of South Africa (Adamson 1961; Gonçalves 1978). A single adventive species G. radiatus (Ruiz \& Pavon) Rohrb. from the Americas was referenced in some West African countries (Berhaut 1967, 1979; Lisowski 2009; Thiombiano et al. 2012; Schmidt et al. 2017). Additionally, it is postulated that G. lotoides and G. oppositifolius seem to freely hybridize in Africa with a large number of intermediates (Adamson 1961; Jeffrey 1961; Gonçalves 1970, 1978). Numerous specimens usually labelled as "G. lotoides $\times$ G. oppositifolius" are present in many herbaria. The reason for this identification is because of the less prominent stellate pubescence in these Glinus specimens compared to the typical densely pubescent specimens of $G$. lotoides. However, such hybrids were not reported from other parts of the Old World.

In a previous carpological study of all Molluginaceae (Sukhorukov et al. 2018), the disparity of many specimens belonging to the same Glinus species in the herbaria visited was noted. In fact, the limited number of diagnostic characters used and absence of detailed taxonomic treatment do not allow for an evaluation of the real diversity of Glinus in tropical Africa, the most species-rich region of the genus in the world. For this reason, a critical study of the taxonomy, morphology and distribution of the genus in Sub-Saharan Africa would be desirable. Therefore, the main aims of the present study are: (1) to conduct an expanded molecular phylogenetic analysis of Glinus worldwide, with further implications on its divergence and origin; (2) to deeply investigate the morphology and species distribution of Glinus in tropical Africa, the most species-rich region, and to provide precise diagnoses through an updated taxonomic treatment. 


\section{Material and methods}

\section{Phylogenetic analysis}

\section{Taxon sampling}

In the molecular phylogenetic analysis, 149 accessions representing 31 species and 10 genera including outgroups were sampled. Except for the Indian G. ononoides where samples could not be amplified because of no recent collection, all other Glinus species were sampled. In total, nine Glinus species representing their entire distribution were sampled. A list of all samples used in this study is presented in Table 1.

Table I. Voucher information and GenBank accession numbers for the species of Molluginaceae and outgroups included in the phylogenetic analysis (arranged in alphabetical order). The newly sequenced samples are highlighted in bold.

\begin{tabular}{|c|c|c|c|c|}
\hline Species & Voucher & ITS & $r b c L$ & trnK-matK \\
\hline Glinus bainesii 8 & $\begin{array}{c}\text { Botswana, Khwai River floodplain, Moremi Game Reserve, } 21 \text { Nov } \\
\text { 2007, A. Heath \& R. Heath } 1417(\mathrm{~K}) ;\end{array}$ & MW280260 & MW275761 & MW286109 \\
\hline Glinus bainesii 40 & $\begin{array}{l}\text { Zimbabwe, Masvingo prov., Chiredzi, } 31 \text { May 1971, S. Mari } 1273 \\
\text { (LE); }\end{array}$ & MW280259 & MW275762 & MW286110 \\
\hline Glinus dictamnoides 18 & $\begin{array}{l}\text { Yemen, Habban, } 2 \text { Mar 1997, M. van Slageren \& A. Al Gifri s.n. } \\
\text { (LE); }\end{array}$ & MW280251 & MW275753 & MW286101 \\
\hline Glinus dictamnoides 41 & India, [without exact location] 20 Feb 1955, Baldev 7 (MW) & MW280250 & MW275752 & MW286100 \\
\hline Glinus hirtus 3 & $\begin{array}{c}\text { Tanzania, Kagera region, Ngara, } 6 \text { Sep 1960, R. Tanner } 5126 \\
\text { (BR0000017454308) }\end{array}$ & MW280247 & MW275760 & MW286108 \\
\hline Glinus hirtus 6 & $\begin{array}{l}\text { Malawi, Central Region, Nkhotakota distr., } 13 \text { May 1986, I.H. } \\
\text { Patel } \mho R \text { R.B. Kwatha } 3184 \text { (BRLU0026262); }\end{array}$ & MW280249 & MW275758 & MW286106 \\
\hline Glinus hirtus 32 & $\begin{array}{c}\text { Mali, nr Bamako, Niger river, Sotuba, } 4 \text { Jul 1973, D. N'Golo } 1291 \\
\text { (WAG0319754) }\end{array}$ & MW280248 & MW275759 & MW286107 \\
\hline Glinus lotoides 9 & $\begin{array}{l}\text { Mali, Koulikoro Region, Koulikoro, } 6 \text { May 1993, R. Ehrlich } 463 \\
\text { (B100048300) }\end{array}$ & - & MW275747 & MW286095 \\
\hline Glinus lotoides 19 & $\begin{array}{l}\text { Eritrea, Northern Red Sea region, Wekiro, } 31 \text { Jan 1960, D.J. } \\
\text { Greathead 139(BM) }\end{array}$ & MW280254 & MW275746 & MW286094 \\
\hline Glinus lotoides 20 & Niger, Touaret, 10 Dec 1965, G. Popov 138 (BM) & MW280252 & MW275748 & MW286096 \\
\hline Glinus lotoides 37 & Australia, Queensland, 4 Sep 1984, J.R. Clarkson 5494 (LE) & MW280253 & MW275749 & MW286097 \\
\hline $\begin{array}{l}\text { Glinus "lotoides" } \\
\text { (American sample) }\end{array}$ & USA, California, Ertter 8854 \& 8859 (NY) & KT907409 & FN824412 & FN825692 \\
\hline Glinus oppositifolius & Taiwan, Huang \& Huang 14175 (NY) & KT907366 & FN824415 & FN825695 \\
\hline Glinus oppositifolius & Australia, Barbidge 5949 (ANH) & - & FN824415 & FN825696 \\
\hline Glinus oppositifolius & China, Xisha Islands, Anonymous s.n. (without herbarium acronym) & MH768251 & - & - \\
\hline Glinus oppositifolius & China, Xisha Islands, Anonymous s.n. (without herbarium acronym) & MH768252 & - & - \\
\hline Glinus oppositifolius & Tanzania, Balslev $630(\mathrm{NY})$ & - & FN824414 & FN825694 \\
\hline Glinus oppositifolius 34 & India, Goa State, Dec 2018, A. Sukhorukov s.n. (MW) & MW280255 & MW275755 & MW286103 \\
\hline $\begin{array}{l}\text { Glinus oppositifolius var. } \\
\text { keenanii } 4\end{array}$ & $\begin{array}{c}\text { Zambia, Western Province, Bulozi plain near Mongu, Oct 1993, } \\
\text { M.G. Bingham } 9743 \text { (WAG0334359) }\end{array}$ & MW280256 & MW275754 & MW286102 \\
\hline Glinus orygioides 35 & Australia, Lake Eyre, 29 Sep 2007, M.J. Thorpe \& al. 119 (LE) & MW280263 & MW275763 & MW286111 \\
\hline Glinus radiatus & USA, Thomas $114677(\mathrm{NY})$ & KT907410 & FN824417 & FN825697 \\
\hline Glinus radiatus 25 & Brazil, Bahia, 2 Nov 1988, R.M. Harley \& al. 25863 (W) & MW280258 & MW275756 & MW286104 \\
\hline Glinus setiflorus & Kenya, Burney \& al. T46 (NY) & KT907367 & N824418 & FN825698 \\
\hline Glinus setiflorus 38 & $\begin{array}{l}\text { Kenya, Kitui county, Ukasi Dam, } 3 \text { Aug 2006, L. Festo \& Q. Luke } \\
\text { 2813(LE); }\end{array}$ & MW280257 & MW275757 & MW286105 \\
\hline Glinus zambesiacus 29 & $\begin{array}{c}\text { Zambia, Luapula prov., Samfya, } 21 \text { Apr 1989, G. Pope \& al. } 2194 \\
\text { (BR0000018269093) }\end{array}$ & MW280261 & MW275751 & MW286099 \\
\hline Glinus zambesiacus 42 & $\begin{array}{l}\text { Zambia, Southern prov., Namwala, } 9 \text { Jan 1957, E.A. Robinson } \\
2101 \text { (BR0000018269581) }\end{array}$ & MW280262 & MW275750 & MW286098 \\
\hline
\end{tabular}




\begin{tabular}{|c|c|c|c|c|}
\hline Species & Voucher & ITS & $r b c L$ & trnK-matK \\
\hline \multicolumn{5}{|l|}{ outgroup } \\
\hline Adenogramma glomerata & South Africa, Ogburn 142 (BRU) & KT907379 & FN824408 & FN825689 \\
\hline Adenogramma teretifolia & South Africa, Ogburn 156 (BRU) & KT907381 & FN824410 & FN825691 \\
\hline $\begin{array}{l}\text { Hypertelis cerviana_l } \\
\text { (sub Mollugo cerviana) }\end{array}$ & Namibia, Potgieter $225(\mathrm{~K})$ & KT907402 & FN824427 & FN825707 \\
\hline $\begin{array}{l}\text { Hypertelis cerviana_2 } \\
\text { (sub Mollugo cerviana) }\end{array}$ & Burkina Faso, Ataholo 1809 (FR) & KT907392 & FN824435 & FN825715 \\
\hline $\begin{array}{l}\text { Hypertelis fragilis } \\
\text { (sub Mollugo fragilis) }\end{array}$ & Angola, Gossweiler $6(\mathrm{~K})$ & KT907397 & FN824441 & FN825723 \\
\hline Hypertelis spergulacea & Namibia, Thulin \& Larsson 11962 (UPS) & KT907407 & - & - \\
\hline Hypertelis spergulacea & Namibia, Giess et al. $5366(\mathrm{~K})$ & - & FN824420 & FN825700 \\
\hline Mollugo flavescens & Ecuador, Galapagos Islands, Wheeler et al. 17 (NY) & KT907417 & FN824438 & FN825720 \\
\hline Mollugo floriana & Ecuador, Galapagos Islands, Eliasson $741(\mathrm{~K})$ & KT907413 & FN824440 & FN825722 \\
\hline Mollugo snodgrassii & Galapagos Islands, Howell 9450 (NY) & KT907411 & FN824457 & FN825738 \\
\hline Mollugo tenella & Namibia, Merxmüller \& Giess 3316 (NY) & KT907414 & FN824458 & FN825739 \\
\hline Mollugo verticillata_1 & no voucher information & MH768259 & MH767665 & MH767966 \\
\hline Mollugo verticillata_2 & Bolivia, Nee 37372 (G) & KT907368 & FN824474 & FN825743 \\
\hline $\begin{array}{l}\text { Paramollugo angustifolia } \\
\text { (sub Mollugo angustifolia) }\end{array}$ & Somalia, Thulin et al. 7606 (UPS) & KT907356 & FN824422 & FN825702 \\
\hline $\begin{array}{l}\text { Paramollugo decandra (sub } \\
\text { Mollugo decandra) }\end{array}$ & Madagascar, Croat $30852(\mathrm{~K})$ & KT907358 & FN824437 & FN825718 \\
\hline $\begin{array}{l}\text { Paramollugo nudicaulis } \\
\text { (sub Mollugo nudicaulis) }\end{array}$ & India, Devi s.n. (CANB) & KT907365 & FN824451 & FN825733 \\
\hline Pharnaceum detonsum & South Africa, Fries 764 (NY) & KT907416 & FN824463 & FN825745 \\
\hline Pharnaceum incanum & South Africa, Ogburn 148 (BRU) & KT907387 & FN824466 & FN825748 \\
\hline Pharnaceum lanuginosum & South Africa, Ogburn 161 (BRU) & KT907385 & FN824469 & FN825752 \\
\hline Polpoda capensis & South Africa, Acocks 17405 (CANB) & KT907384 & FN824470 & FN825753 \\
\hline Psammotropha obovata & South Africa, Hilliard \& Burtt 7045 (K) & KT907383 & FN824471 & FN825754 \\
\hline $\begin{array}{l}\text { Psammotropha } \\
\text { quadrangularis }\end{array}$ & South Africa, Ogburn 160 (BRU) & KT907382 & FN824472 & FN825755 \\
\hline $\begin{array}{l}\text { Suessenguthiella } \\
\text { scleranthoides }\end{array}$ & South Africa, Acocks 18950 (K) & KT907390 & FN824473 & FN825756 \\
\hline $\begin{array}{l}\text { Trigastrotheca molluginea } \\
\text { (sub Mollugo molluginea) }\end{array}$ & Australia, Telford 11746 (CANB) & KT907408 & FN824443 & FN825725 \\
\hline $\begin{array}{l}\text { Trigastrotheca pentaphylla } \\
\text { (sub Mollugo pentaphylla) }\end{array}$ & India, $n / a$ & KT907377 & FN824455 & FN825737 \\
\hline
\end{tabular}

\section{DNA extraction, amplification and sequencing}

5-10 mg of dried herbaria leaf samples was used to isolate DNA using the CTAB protocol (Doyle and Doyle 1987). One nuclear (the nuclear ribosomal internal transcribed spacer, nrITS) and two plastid markers (the coding gene rbcL and the region encompassing $\operatorname{trn} K$ introns and $m a t K$ coding genes, $\operatorname{trn} K$-matK) were selected for phylogenetic analysis. The primers ITS 4 and ITS5 (White et al. 1990) were used to amplify the ITS region. The $r b c L$ and matK-trnK primer sequences were taken from Christin et al. (2011). Due to the fact that the samples were taken from herbaria and had a rather long storage term, various combinations of the forward primers trnK-matK_For A, C, $\mathrm{G}$, and $\mathrm{H}$ and the reverse primers trnK-matK_Rev C, D, F and I were used. For $r b c L$, two external rbcL_4_For and rbcL_1353 and two internal primers rbcL_629_For and rbcL_760_Rev were used (Christin et al. 2011).

PCR reactions for all primers were performed in a total volume of $25 \mu \mathrm{l}$, using $5 \mu \mathrm{l}$ DNA $(10 \mathrm{ng} / \mu \mathrm{l}), 1 \mu \mathrm{l}$ of each primer, $0.5 \mu \mathrm{l}$ Encyclo polymerase (Evrogen, Russia), $0.5 \mu \mathrm{l} 50 \times \mathrm{dNTP}, 5 \mu \mathrm{l} 10 \times$ Encyclo buffers and $14.5 \mu \mathrm{mQ}$. 
PCR amplification of nrITS primers was performed under the following conditions: initial denaturation for $3 \mathrm{~min}$ at $94^{\circ} \mathrm{C} ; 37$ cycles of $1 \mathrm{~min}$ denaturation at $94^{\circ} \mathrm{C}, 30 \mathrm{~s}$ annealing at $51{ }^{\circ} \mathrm{C}, 150 \mathrm{~s}$ extension at $72{ }^{\circ} \mathrm{C}$, and final extension of $10 \mathrm{~min}$ at $72{ }^{\circ} \mathrm{C}$ (Thulin et al. 2016). PCR amplification for $r b c L$ was performed under the following conditions: initial denaturation for $10 \mathrm{~min}$ at $94^{\circ} \mathrm{C} ; 34$ cycles of $30 \mathrm{~s}$ denaturation at $94^{\circ} \mathrm{C}, 30 \mathrm{~s}$ annealing at $48{ }^{\circ} \mathrm{C}, 150 \mathrm{~s}$ extension at $72^{\circ} \mathrm{C}$, and final extension of $10 \mathrm{~min}$ at $72^{\circ} \mathrm{C}$. The following PCR program was used for matK$\operatorname{trn} K$ primers: initial denaturation for $10 \mathrm{~min}$ at $94^{\circ} \mathrm{C} ; 34$ cycles of $30 \mathrm{~s}$ denaturation at $94^{\circ} \mathrm{C}, 30 \mathrm{~s}$ annealing at $51{ }^{\circ} \mathrm{C}, 2 \mathrm{~min}$ extension at $72{ }^{\circ} \mathrm{C}$, and final extension of 10 min at $72^{\circ} \mathrm{C}$.

PCR products were cleaned with Cleanup Mini BC023S Kit (Evrogen, Russia). Sanger sequencing was carried at Evrogen JSC (Moscow, Russia) using the same primers as in the PCR.

\section{Phylogenetic inference and molecular dating}

Sequences were aligned using MUSCLE v.3.5 (Edgar 2004) and the alignment was adjusted manually using PhyDe (version 0.9971; Müller et al. 2010). Three separate analyses were performed for the nuclear and plastid DNA datasets using maximum parsimony (MP), Bayesian inference (BI) and maximum likelihood (ML). Due to a conflict between $G$. zambesiacus and G. setiflorus, all subsequent analyses were conducted using the separate datasets. Models of nucleotide substitution were chosen according to the Akaike information criterion using jModelTestv.2.1.7 (Guindon and Gascuel 2003; Darriba et al. 2012) for each gene separately. The best-fit substitution model for both the nuclear and plastid datasets was GTR + G. For the ML analyses, we used RAxML Version 8 (Stamatakis 2014). Bootstrap analyses were conducted with 2500 replicates for ML. Parsimony analyses were conducted in PAUP* 4.0a162 (Swofford 2002) with the following settings: all characters have equal weight, MaxTrees set to 1000 (auto increased by 1000), TBR branch swapping and with 20000 jackknife (JK) replicates to calculate node support. Final trees were edited in TreeGraph ver. 2.14.0 (Stöver and Müller 2010).

Divergence times for Glinus were estimated using a Bayesian uncorrelated lognormal relaxed clock under a birth-death speciation process (Gernhard 2008) for the nuclear and plastid datasets separately. We selected a normal distribution for the secondary calibration with a standard deviation of 8.5, equivalent to the $95 \%$ HPD estimate of Yao et al. (2019) for the crown of Molluginaceae. Four independent MCMC analyses were run, each of 20 million generations sampling every 2000. The analyses were run using BEAST 2.4.5 (Bouckaert et al. 2014) on the CIPRES Science Gateway 3.3 (https://www.phylo.org; Miller et al. 2010). Output log files were analyzed using TRACER 1.6 (Rambaut et al. 2014) to assess convergence and ESS of all parameters. As "burn-in", $10 \%$ of samples were removed prior to combining the independent runs using LOGCOMBINER 2.4.5 (Bouckaert et al. 2014). The MCC tree was generated using TREEANNOTATOR 2.4.5 (Bouckaert et al. 2014). 


\section{Biogeographical analysis}

Geographical distributions of all species were compiled from herbarium specimens and field work (see section "Field and herbarium studies" below). Due to the wide distribution of some species ( $G$. hirtus, G. lotoides, G. oppositifolius, G. radiatus), the biogeographical analysis is based on the continents and not the floristic provinces. Four geographical areas were identified: A - Africa including Madagascar; B - Asia; $\mathrm{C}$ - Australia, and D - America (including Galapagos Islands). The BI gene trees were pruned to remove all duplicate accessions and $G$. dictamnoides using the drop.tip function in the package ape (Paradis et al. 2004). The nuclear and plastid gene trees used for the analyses had 32 accessions each corresponding to 31 species. Two accessions of G. lotoides were included representing the Old World and the American populations. The coded geographic data is available in Table 2.

Ancestral range estimation (ARE) was conducted using the R package "BioGeoBEARS" (Matzke 2013, 2014). Out of the six models explored in this study, the $\mathrm{DEC}+\mathrm{J}$ model was the best fit based on the AIC and likelihood ratio test (LRT) results (see Table 3). The analyses were unconstrained (without possible dispersal routes or ancestral areas assumed a priori). We allowed the inferred ancestor to occupy a maximum of three areas, corresponding to the maximum number of areas occupied by any extant species.

Based on the likelihood and AIC values, the best fit model was the DEC $+\mathrm{J}$ model for both nuclear and plastid datasets (Table 3). Both datasets had the same results and only varied at the divergence times.

\section{Multivariate analysis}

The same species set of Glinus as in the molecular phylogenetic analysis were included in the character matrix. The varieties of G. oppositifolius (var. glomeratus and var. keenanii) that deviate in some states of the studied characters as well as $G$. ononoides and G. sessiliflorus were not included. The multivariate analysis aims to test whether the morphological and carpological character subdivision corresponds with the phylogenetic reconstructions. In our previous papers, multivariate analysis provided a good support for the non-stochastic distribution of the characters in major clades of the entire Molluginaceae (Sukhorukov et al. 2018) and the genus Microtea, Microteaceae (Sukhorukov et al. 2019).

Different Glinus species were classified by group average linkage algorithm of cluster analysis constructed on a Gower similarity matrix (Gower 1971) based on seventeen characters including general morphology (life history, pubescence, leaves) and reproductive traits. This approach recognizes the species grouping based on similar characters, but does not provide a true phylogenetic context. The reliability of grouping was assessed at the level $\mathrm{p}<0.05$ using SIMPROF algorithm (Clarke 1993; Clarke and Warwick 2001). Calculations were performed using PRIMER 6.1.6 statistical software (Clarke and Gorley 2006). 
Table 2. The coding of the geographical areas of Glinus species and outgroup (all - Molluginaceae).

\begin{tabular}{|c|c|}
\hline Taxon & Geographical areas \\
\hline G. bainesii & A \\
\hline G. hirtus (known as G. dahomensis nom. inval.) & A \\
\hline G. lotoides & A, B, C \\
\hline G. lotoides (American sample) & $\mathrm{D}$ \\
\hline G. oppositifolius & $A, B, C$ \\
\hline G. orygioides & $\mathrm{C}$ \\
\hline G. radiatus & $\mathrm{D}$ \\
\hline G. setiflorus & A \\
\hline G. zambesiacus & A \\
\hline \multicolumn{2}{|l|}{ Outgroup } \\
\hline Adenogramma glomerata & A \\
\hline Adenogramma teretifolia & A \\
\hline Hypertelis cerviana & $A \& B$ \\
\hline Hypertelis fragilis & A \\
\hline Hypertelis spergulacea & A \\
\hline Mollugo flavescens & $\mathrm{D}$ \\
\hline Mollugo floriana & $\mathrm{D}$ \\
\hline Mollugo snodgrassii & $\mathrm{D}$ \\
\hline Mollugo tenella & A \\
\hline Mollugo verticillata & $\mathrm{D}$ \\
\hline Paramollugo angustifolia & A \\
\hline Paramollugo decandra & A \\
\hline Paramollugo nudicaulis & $A \& B$ \\
\hline Polpoda capensis & A \\
\hline Pharnaceum detonsum & A \\
\hline Pharnaceum incanum & A \\
\hline Pharnaceum lanuginosum & A \\
\hline Psammotropha obovata & A \\
\hline Psammotropha quadrangularis & A \\
\hline Suessenguthiella scleranthoides & A \\
\hline Trigastrotheca molluginea & $\mathrm{C}$ \\
\hline Trigastrotheca pentaphylla & B \\
\hline
\end{tabular}

Table 3. Results of the biogeographical analysis using BioGeoBEARS.

\begin{tabular}{lccccccc}
\hline & \multicolumn{3}{c}{ Nuclear and plastid datasets } & & \\
\hline & LnL & numparams & d & e & j & AIC & AIC_wt \\
\hline DEC & -51.29 & 2 & 0.0083 & $1.00 \mathrm{E}-12$ & 0 & 106.6 \\
DEC+J & -48.91 & 3 & 0.0063 & $1.00 \mathrm{E}-12$ & 0.023 & 103.8 & 0.19 \\
DIVALIKE & -53.03 & 2 & 0.0099 & $1.00 \mathrm{E}-12$ & 0 & 110.1 & 0.033 \\
DIVALIKE+J & -51.72 & 3 & 0.0079 & $1.00 \mathrm{E}-12$ & 0.016 & 109.4 & 0.044 \\
BAYAREALIKE & -66.51 & 2 & 0.012 & 0.031 & 0 & 137 \\
BAYAREALIKE+J & -55.51 & 3 & 0.005 & $1.00 \mathrm{E}-07$ & 0.035 & 117 & 0.001 \\
\hline
\end{tabular}

\section{Carpological study}

The seeds were investigated using scanning electron microscopy (SEM) and anatomically. The hard seed coat does not require any special preparation prior to SEM due to absence of any trichomes on its surface. The seed colliculae if present are the thickenings of the outer walls of the testa cells. After sputter coating the material with goldpalladium, the SEM observations were made with a JSM-6380 microscope (JEOL 
Ltd., Japan) in the Laboratory of Electron Microscopy of Moscow State University. The anatomical cross-sections of seeds were prepared using a rotary microtome $\mathrm{Mi}$ crom HM 355S (Thermo Fisher Scientific, USA). Before sectioning, the seeds were soaked in water:alcohol:glycerin (1:1:1) solution, dehydrated in an ethanol dilution series and embedded in Technovit 7100 resin (Heraeus Kulzer, Germany). The crosssections were observed using a Nikon Eclipse Ci microscope and photographed with a Nikon DS-Vil camera (Nikon Corporation, Japan) at the Department of Higher Plants (Moscow State University).

The list of samples used for the SEM is provided in Table 4.

\section{Choosing the territory for taxonomic study}

Due to the fact that Glinus has the highest taxonomic diversity in the tropics of Africa but is represented only by a single widespread species (G. lotoides) in North Africa (Maire 1962; Boulos 1999) and a poorly known local endemic in Luxor (G. runkewitzii Täckh. \& Boulos), which is closely related to G. lotoides (Täckholm and Boulos 1972), we thus exclude the northern part of the continent (Algeria, Egypt, Libya, Morocco

Table 4. List of species and vouchers used in the carpological analysis. The specimens used for both anatomy and SEM analyses are marked with an asterisk $\left(^{*}\right)$ after the herbarium acronym. The samples of the widely distributed species G. lotoides and G. oppositifolius originated from different regions of the World.

\begin{tabular}{|c|c|}
\hline Species & Origin of the material \\
\hline G. bainesii & Botswana, Ngamiland, $100 \mathrm{~m} \mathrm{~S}$ of Samudupe newbridge, 19 Feb 2008, B. Farrington et al. 486 (K)*; \\
\hline G. dictamnoides & $\begin{array}{c}\text { Kenya, South province, Magadi road, } 3000 \mathrm{ft}, 8 \text { Aug 1943, P.R.O. Bally } 2679(\mathrm{G})^{*} \text {; Sri Lanka, Central province, Sep } \\
\text { 1974, D. B. Sumithraarachchk } 496(\mathrm{~K}) ;\end{array}$ \\
\hline G. hirtus & $\begin{array}{l}\text { South Africa, Northern Cape, Henkries, } 30 \text { Nov } 1897 \text {, B. Schlechter s.n. (G); Malawi, Zomba, 2500-3500 ft, [without } \\
\text { date] A. Whyte s.n. (G); Senegal, [without exact location and date] Perrottet } 373 \text { (G); Somalia, Ganaane to Marro } \\
\text { Mogale Umberto I, Mar 1893, D. Riva } 736 \text { (G); Nigeria, Niger prov., Bida distr., } 1 \text { Mar 1968, B.O. Daramola \& A. } \\
\text { Binuyo } 61930 \text { (K)*; Burkina Faso, Kompienga, } 40 \mathrm{~km} \mathrm{E} \mathrm{of} \mathrm{Tindangou,} 2 \text { May 2003, L. Sanou \& M. van Slageren } \\
1352 \text { (K); DR Congo, Inkisi river, } 17 \text { Oct 2007, Nsimundele } 2060 \text { (BR0000000530230); }\end{array}$ \\
\hline G. lotoides & $\begin{array}{c}\text { Indonesia, Java, 1908, H. Winkler s.n. (BM); Madagascar [Boeny Region], Madirovalo, } 4 \text { Oct 1930, M. Decary } 8194 \\
\text { (G); Israel, Upper Jordan valley, } 19 \text { Jul 1943, T. Kushnir s.n. (HUJ)*; Australia, Northern territory, Simpson desert, Jul } \\
\text { 1968, A.E. Orchard } 759 \text { (K); Nigeria, Kainji Lake, } 21 \text { Jul 1973, R. Linnavuori s.n. (H1209977)*; Niger, } 100 \text { km S of } \\
\text { Agadez, } 23 \text { Nov 1985, C. Pase } 3149 \text { (K); }\end{array}$ \\
\hline G. ononoides & [India, leg. D. Freyn] (G00808773)* \\
\hline G. oppositifolius & $\begin{array}{l}\text { Philippines, [no location and year] Blanco } 385 \text { (LE); India [state of Assam], Cachar [distr.], Mar 1873, R.L. Keenan s.n. } \\
\text { (K000641798), type of Mollugo hirta var. keenanii; [Vietnam] nr Hanoi, Jun 1891, B. Balansa 4613 (K000641793), } \\
\text { as G. herniarioides; DR Congo, Boma, } 1 \text { Aug 1913, Bequaert } 536 \text { (BR000000895538) (var. keenanii); Tanzania, } \\
\text { Kyimbila distr. N of Lake Nyasa, 1915, A. Stolz s.n. (K)*; [DR Congo] Mateba, 14 Dec 1912, R. Verschueren 203 } \\
\text { (BR000000895505); Sierra Leone, nr Kasanko, 13 May 1951, P. Adams 225 (K); Tanzania, [Tanga Region] Handeni } \\
\text { distr., Horogwe to Handeni, 18 Nov 1955, E. Milne-Redhead \& P. Taylor 7337 (K) (var. keenanii); Zambia, Mongu } \\
\text { distr., Kande Lake, } 8 \text { miles NE of Mongu, 11 Nov 1959, R. B. Drummond \& A.J.Cookson 6335 (E); Angola, Cuando- } \\
\text { Cubango prov., Longa, } 1360 \text { m, 17 Mar 1960, E.J. Mendes 3155 (M) (var. glomeratus); DR Congo, 26 km NW } \\
\text { of Lubumbashi, Lupoto, } 2 \text { Mar 1961, A. Schmitz 7129 (P05307011) (var. glomeratus); DR Congo, Katanga prov., } \\
\text { Kundelungu Plateau, Lualaba, 1700 m, Mar 1969, S. Lisowski \& al. 4053 (BR0000018268348) (var. glomeratus); } \\
\text { India, Goa State, Dec 2018, A. Sukhorukov s.n. (MW)*; }\end{array}$ \\
\hline G. orygioides & Australia, Eyre Lake, 29 Sep 2007, M.J. Thorpe et al. 119 (K)*; \\
\hline G. radiatus & $\begin{array}{l}\text { Cuba, 1824, Anonymous s.n. (BR); Dominican Rep., Santo Domingo, Jul 1912, M. Fuertes 1859 (E); Mexico, } \\
\text { Temascaltepec distr., Feb 1933, G.B. Hinton } 4065 \text { (BR)*; Venezuela, Estado Guárico, } 8 \text { May 2010, A. Fernández et al. } \\
27692(\mathrm{G}) ;\end{array}$ \\
\hline G. sessiliflorus & Australia, Northern Territory, Annaburroo, 8 Sep 2002, B.J. Lepschi \& J.R. Connors 4854 (W)*; \\
\hline G. setiflorus & $\begin{array}{c}\text { Ethiopia, Ogaden, nr Mardere, } 2 \text { Dec 1953, G. Popov } 1143 \text { (K)*; Somalia, El Buur distr., } 27 \text { km S of Guri Ceel, } 6 \text { Jun } \\
\text { 1988, P. Kuchar } 17836 \text { (K); }\end{array}$ \\
\hline G. zambesiacus & $\begin{array}{c}\text { Zambia, Barotseland [Western province], Mongu, } 6 \text { Feb 1966, Robinson } 6780(\mathrm{M})^{*} \text {; DR Congo, Katanga prov., } \\
\text { Pweto, } 18 \text { May 1971, F. Malaisse } 6767(\mathrm{BR} 0000018269567) .\end{array}$ \\
\hline
\end{tabular}


and Tunisia) from our investigations. The territory under study corresponds to the geographical concept designed for the framework for the investigation of biodiversity and conservation of Sub-Saharan plants (Gautier et al. 2006; Klopper et al. 2006).

\section{Field and herbarium studies}

Field investigations were conducted by the first author (APS) in many regions of $\mathrm{Na}$ mibia in 2017-2018, Tanzania (Arusha and Kilimanjaro Regions, Unguja Island) in 2019 and 2020, in surroundings of Victoria Falls (Zimbabwe), Livingstone (Zambia) and Kasane (Botswana) in 2020. Alison and Roger Heath, Honorary Research Associates at RBG Kew, UK and Research Affiliates at University of Botswana, carried out a 20 -year botanical research project in the Okavango Delta and surrounding areas of the Kalahari Desert and published interim results of the floristic investigations as a book (Heath and Heath 2009). The study of the herbarium material was undertaken by the first author (APS) at B (images), BACH (images), BM, BOL (images), BR, BRLU, COI (images), E, FI (images), FR, FT (images), G, H, HUJ, K, L (incl. U \& WAG), LE, LICS (images), M, MHA, MSB, MW, P, PE (images), PRE (images), RO, STU (images), W, WU, Z (images). Only a part of the images seen from BOL, LISC and PRE were exactly identified and cited in the present article; other specimens from these herbaria requiring more detailed analysis were not cited here. No Glinus specimens were seen from Equatorial Guinea, Lesotho and West Sahara.

Distribution maps are based on the specimens cited in the text and were prepared using SimpleMappr online tool (http://www.simplemappr.net).

\section{Nomenclature}

Protologues of each plant name involved were examined for valid publication, legitimacy, and other nomenclatural issues in agreement with the International Code of Nomenclature for algae, fungi, and plants (Turland et al. 2018). As far as possible, original material was traced and type specimens were cited or designated here.

\section{Results}

\section{Molecular phylogeny and dating}

The combined plastid dataset of $r b c L$ and matK-trnK comprises 4009 aligned bp and 48 accessions while the nrITS dataset has 760 aligned bp and 47 accessions. The ML and BI analyses revealed identical topologies, although slightly different from the MP (see Figs 1, 2). In all three analyses, Glinus is resolved as monophyletic. In the nuclear gene trees, Glinus is sister to Trigastrotheca F.Muell. (Fig 1; BSL 89; PP 0.97) while in the plastid gene trees it is recovered as sister to Mollugo (Fig 2; BSL 100; PP 1). In the parsimony analyses, Glinus is sister to Mollugo in both the plastid (BSP 100) and nuclear (BSP 100) gene trees. 


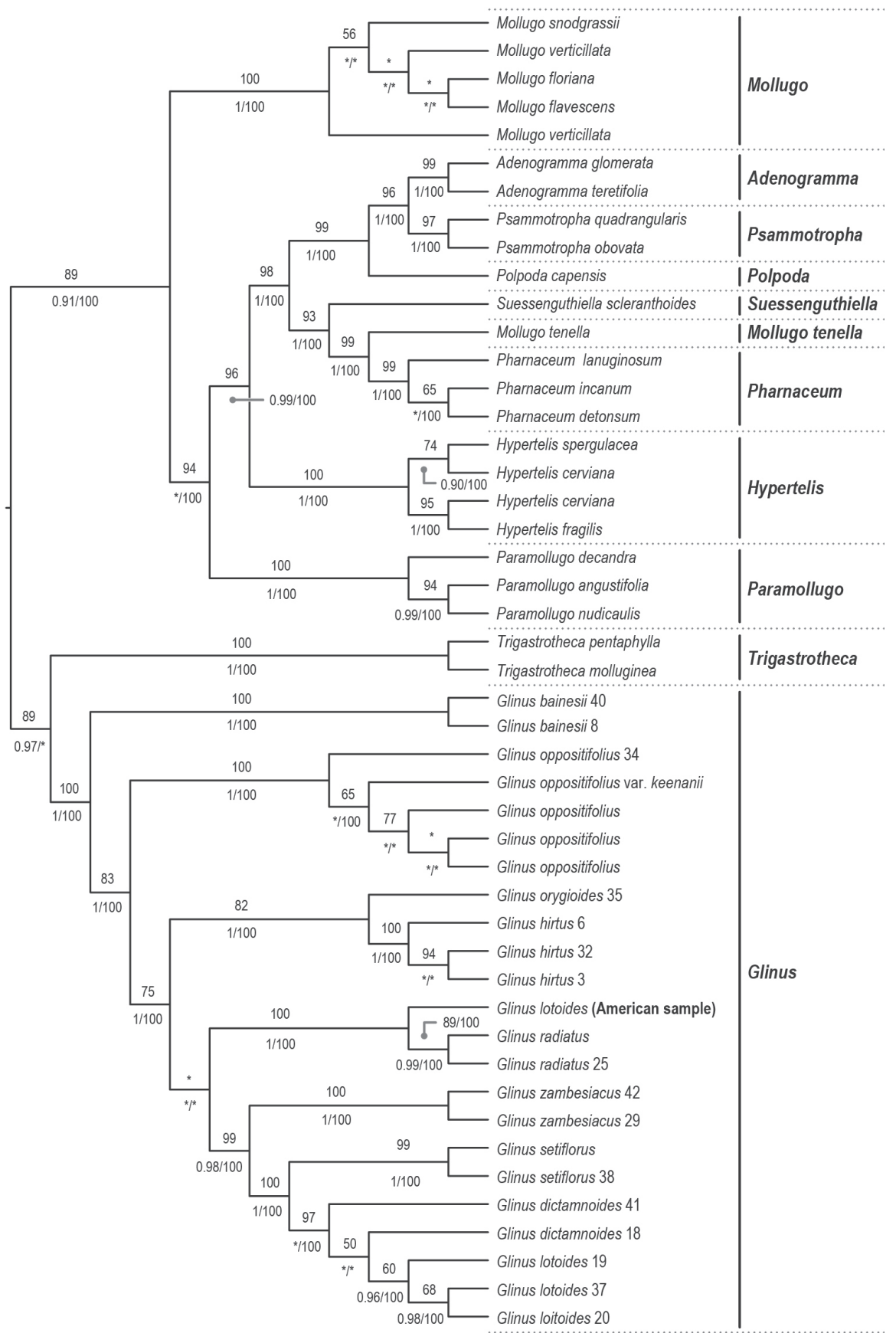

Figure I. Maximum likelihood phylogenetic cladogram of Glinus derived from the nrITS. Values above branches refer to bootstrap values resulting from the ML analysis (only values $\geq 50$ ). Values below branches refer to posterior probabilities resulting from Bayesian inference (only values $\geq 0.95$ ) and bootstrap values resulting from the parsimony analysis (only values $\geq 50$ ). An asterisk $\left(^{*}\right)$ denotes a branch unsupported by either bootstrap values or posterior probability. 


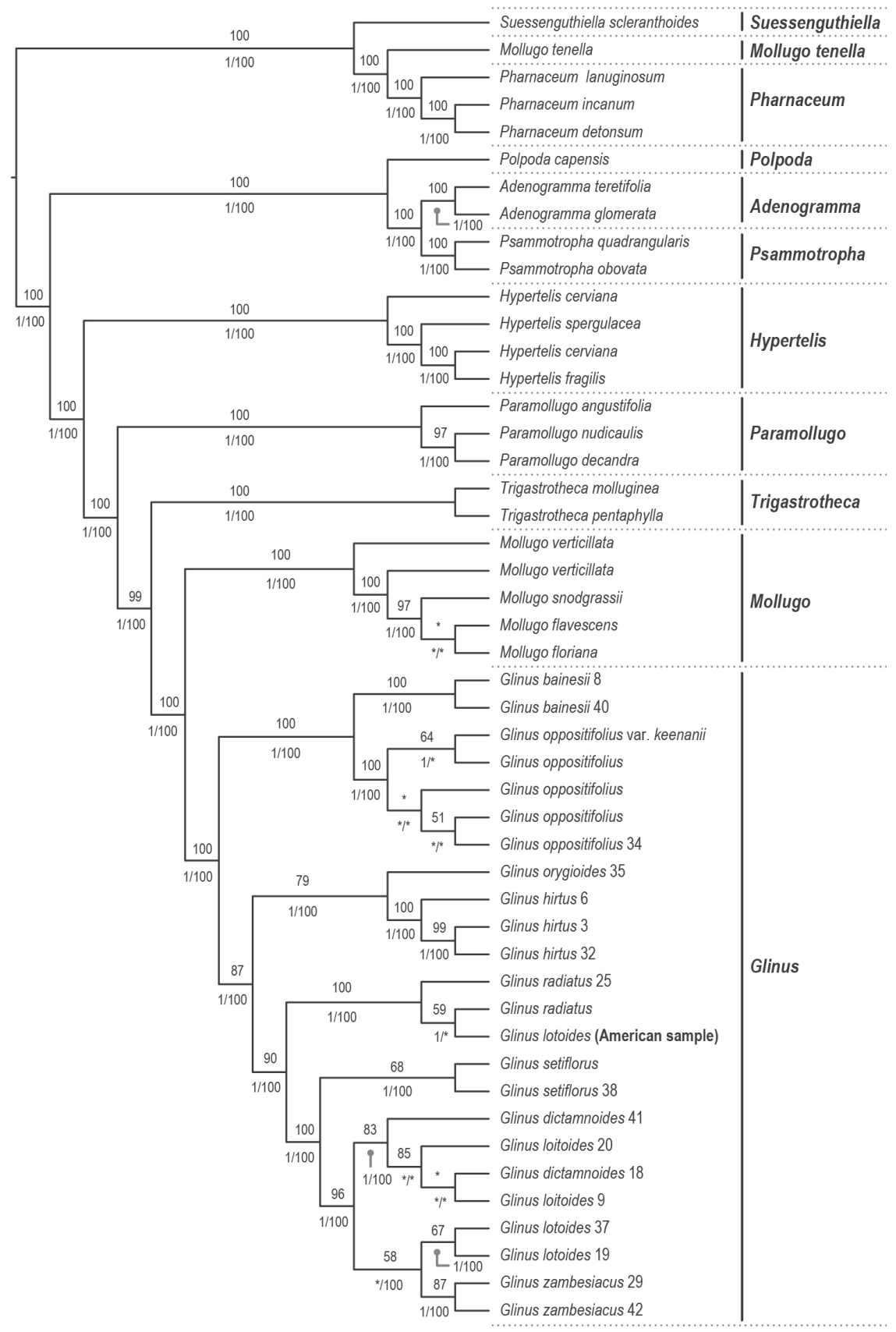

Figure 2. Maximum likelihood phylogenetic cladogram of Glinus derived from the combined plastid matrix (rbcL, trnK-matK). Values above branches refer to bootstrap values resulting from the ML analysis (only values $\geq 50$ ). Values below branches refer to posterior probabilities resulting from Bayesian inference (only values $\geq 0.95$ ) and bootstrap values resulting from the parsimony analysis (only values $\geq 50$ ). An asterisk $\left(^{*}\right)$ denotes a branch unsupported by either bootstrap values or posterior probability. 
In the plastid gene trees, G. bainesii + G. oppositifolius form a clade sister to all other Glinus species. In this clade, $G$. hirtus + G. orygioides are in turn sister to the remaining species. Glinus radiatus plus the northern American G. lotoides sample are sister to a clade composed of G. setiflorus, G. dictamnoides, G. zambesiacus and G. lotoides (Fig. 2).

In the nuclear gene tree, $G$. bainesii is recovered as sister to the remaining species. The G. oppositifolius lineage is recovered as sister to a well-supported clade of (1) G. hirtus + G. orygioides; (2) G. radiatus and the North American G. lotoides and (3) G. zambesiacus as sister to G. setiflorus + G. lotoides + G. dictamnoides (Fig. 1).

The plastid and nuclear gene trees had a conflict regarding the position of G. zambesiacus and G. setiflorus. In the plastid gene tree, G. setiflorus is well-supported (BSL 100; BSP 100; PP 1) as sister to a clade composed of G. zambesiacus, G. dictamnoides and $G$. lotoides whereas in the nuclear gene tree $G$. zambesiacus is well-supported (BSL 99; BSP 100; PP 0.98) as sister to a clade composed of G. setiflorus, G. dictamnoides and G. lotoides (Figs 1, 2).

Except for the crown node of Molluginaceae, the other nodes show very different ages for both the nuclear and plastid gene trees. The nuclear gene tree had much older node ages compared to the plastid gene tree (Fig. 3). Molluginaceae started to diversify during the Late Paleocene at -58.97 mya (95\% HPD $42.07-76.03$ mya) or -58.81 mya (95\% HPD 41.8-76.03 mya) based on the nuclear and plastid trees, respectively. The diversification of Glinus started around the Late Eocene -39.5 mya (stem age, 95\% HPD: 13.33-30.85) or around the Middle Miocene -13.47 mya (stem age, $95 \%$ HPD: 7.82-20.06 mya) for the nuclear and plastid trees, respectively (Fig. 3).
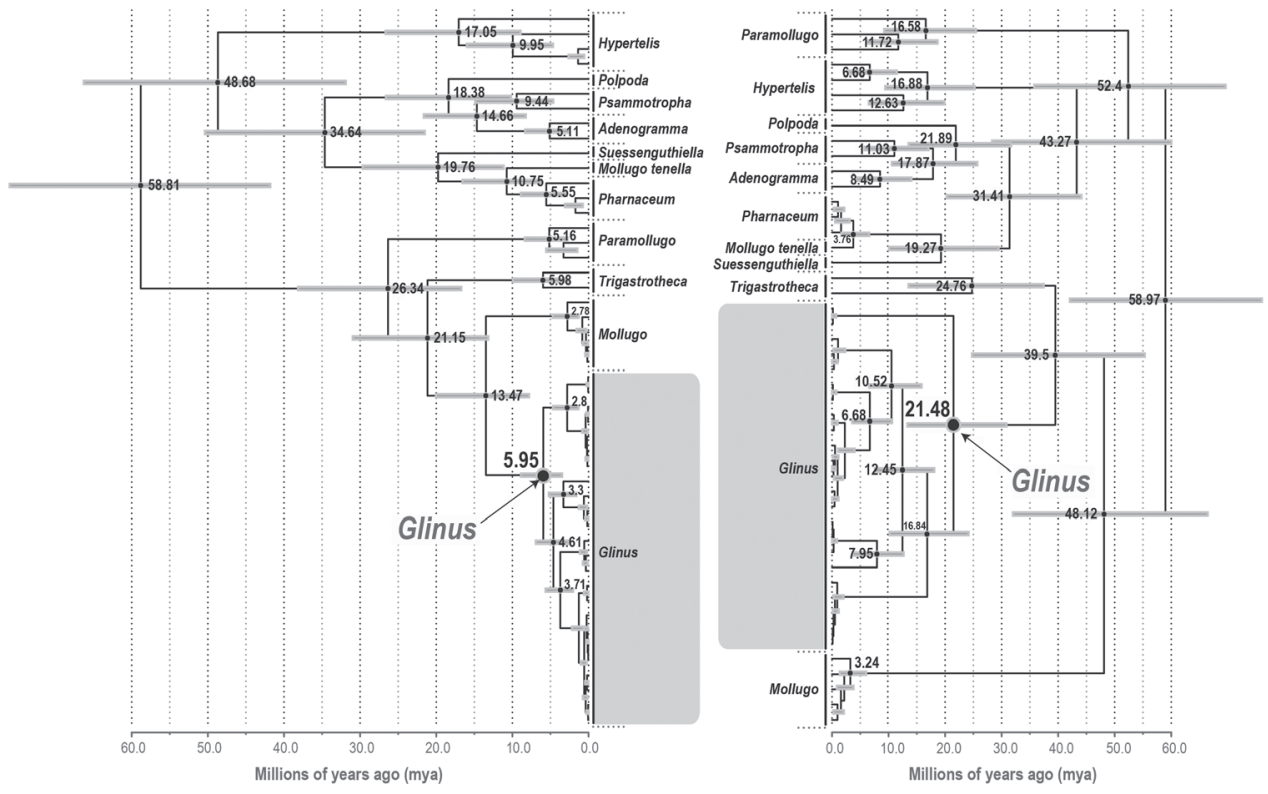

Figure 3. Maximum clade credibility (MCC) tree of Glinus obtained from the BEAST analysis calibrated using secondary calibrations (see Methods). Mean divergence times (values at some nodes) are shown with their 95\% highest posterior density (HPD: grey bars). To the left is the plastid gene tree and to the right the nuclear gene tree, respectively. 


\section{Biogeographical analysis}

In the biogeographical analysis, the nuclear and plastid gene trees based on the reduced data showed the same topology but only varied with the divergence times. The nuclear and plastid trees based on the reduced data showed the same topology, as such similar biogeographic results only differing by node ages. The ancestral area of Glinus is uncertain (see Fig. 4 ACD: $p=0.21$;D: $p=0.18$; ABD: $p=0.16 ; \mathrm{A}: \mathrm{p}=0.10$ ). The ancestral area of the crown node of Glinus remains uncertain (Fig. 4; ABC: $\mathrm{p}=$ $0.23 ; \mathrm{A}: \mathrm{p}=0.19 ; \mathrm{AC}: \mathrm{p}=0.19 ; \mathrm{AC}: \mathrm{p}=0.19 ; \mathrm{AB}: \mathrm{p}=0.14$ ) even though it seems to be connected to Africa. There have been two shifts from Africa, one to Australia for $G$. orygioides and the other to America for G. radiatus and the American G. lotoides clade.

\section{Diagnostic characters revisited}

We coded 17 characters (14 morphological and 3 anatomical characters) used for the multivariate analyses (see Table 5). Out of the 17 characters coded, 10 are used for species delimitation for the first time (characters 4, 7, 8, 10,11,13,14, 15, 16 and 17; see Table 5). The following characters and states were coded.

1. Life form: annual (0); annual to short-lived perennial herb (1); subshrub (2).

2. Pubescence: soft simple hairs (0); stellate hairs (1).

3. Presence of prickles on the stem, leaves and perianth: absent or scattered and unnoticeable (0); present and distinguishable (1).

4. Leaf veins: adaxially not recessed and abaxially not prominent (0); adaxially recessed and abaxially prominent (1).

5. Presence of pedicel: flowers sessile or subsessile (pedicel up to $5.0 \mathrm{~mm}$ long) (0); pedicel more than $5.0 \mathrm{~mm}$ long (1).

6. Flower clusters: usually up to 7-10 flowers (0); more than 10 flowers (1).

Note. Within the state (0), G. setiflorus usually has 1-2 flowers in the cluster, and other species - from 4 to 10 flowers. However, this quantitative difference is not strictly expressed in G. bainesii, G. oppositifolius and G. zambesiacus.

7. Flower buds and closed anthocarp (Fig. 5): ovoid or roundish (0); cylindrical (1).

8. Length of perianth segments in fruiting: up to $5.5 \mathrm{~mm}(0)$; more than $5.5 \mathrm{~mm}(1)$.

9. Number of stamens: $2-7(0) ; 10$ or more (1).

10. Length of anthers: up to $0.6 \mathrm{~mm}(0) ; 0.6-1.0 \mathrm{~mm}(1) ;(1.0) 1.2-1.8 \mathrm{~mm}(2)$.

11. Length of stylodia and stigmas (or style + stigmas): up to $0.6 \mathrm{~mm}(0) ;(0.5) 0.6-$ $1.0 \mathrm{~mm}$ (1); more than $1.0 \mathrm{~mm}(2)$.

12. Stigmas (or style with stigmas): 3 (0); usually 5 (1).

Note. A character "Presence of the style" (united part of the stylodia) is not included in the matrix, because it can be variable within a species. The short style is mentioned in G. lotoides (Hofmann 1973). In G. hirtus, G. lotoides, G. oppositifolius, G. setiflorus and G. zambesiacus the style, if present, is equal in the length to the stigmas.

13. Seed colour: yellow-brown (0); red, brown or reddish-brown (1); dark red or almost black (2). 


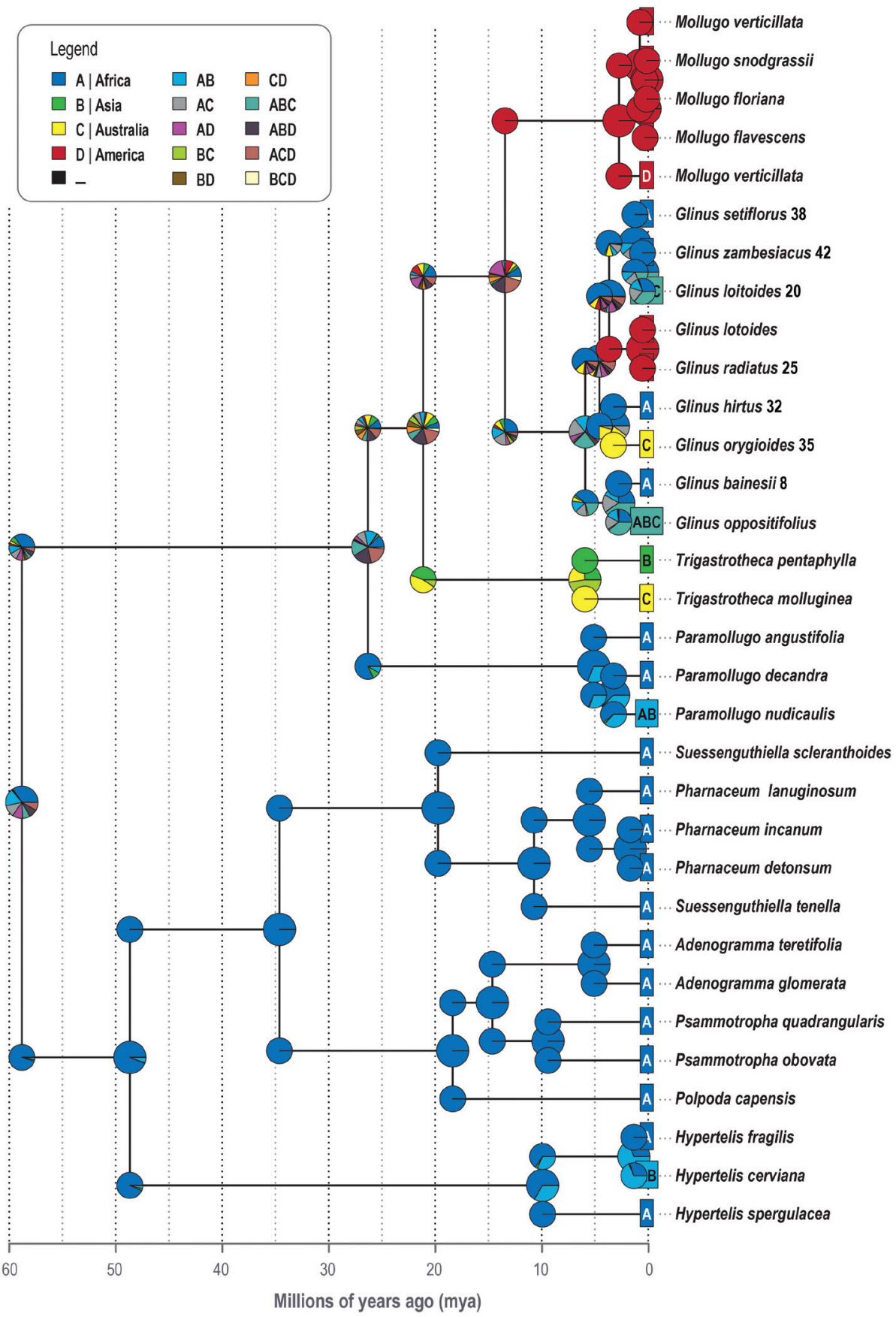

Figure 4. Ancestral range estimation (ARE) based on the reduced MCC tree ("BioGeoBEARS" DEC+J on Glinus unconstrained ancstates: global optim, three areas max. anagenetic dispersal rate, $\mathrm{d}=0.0063$; extinction rate, $\mathrm{e}=0$; cladogenetic dispersal rate, $\mathrm{j}=0.023$; likelihood ratio test, $\mathrm{LnL}=-48.91$ ). Coding of biogeographical areas as shown in the legend. Coding of species areas is given in coloured squares left of each species. Pie charts represent the ancestral area probability inferred for each node. 
Table 5. Coded matrix for multivariate analysis of Glinus species. The varieties of the species that deviate in characters compared with the type variety were not included in the Table. To be consistent with the molecular phylogeny, the same species set was used for the multivariate analysis (G. ononoides and G. sessiliflorus were included in the Table, but they are absent in both molecular and multivariate analyses).

\begin{tabular}{lccccccccccccccccc}
\hline \multicolumn{1}{c}{ Taxon/character states } & $\mathbf{1}$ & $\mathbf{2}$ & $\mathbf{3}$ & $\mathbf{4}$ & $\mathbf{5}$ & $\mathbf{6}$ & $\mathbf{7}$ & $\mathbf{8}$ & $\mathbf{9}$ & $\mathbf{1 0}$ & $\mathbf{1 1}$ & $\mathbf{1 2}$ & $\mathbf{1 3}$ & $\mathbf{1 4}$ & $\mathbf{1 5}$ & $\mathbf{1 6}$ & $\mathbf{1 7}$ \\
\hline G. bainesii & 1 & 0 & 1 & 0 & 1 & 0 & 1 & 1 & 1 & 2 & 2 & 0 & 2 & 0 & 2 & 1 & 1 \\
G. dictamnoides & 0 & 1 & 0 & 1 & 0 & 0 & 0 & 0 & 1 & 1 & 2 & 1 & 2 & 0 & 1 & 1 & 1 \\
G. hirtus & 0 & 1 & 0 & 0 & 0 & 1 & 1 & 0 & 0 & 1 & 1 & 0 & 1 & 0 & 1 & 1 & 1 \\
G. lotoides (Old World) & 0 & 1 & 0 & 1 & 0 & 0 & 0 & 1 & 1 & 1 & 2 & 1 & 2 & 0 & 1 & 1 & 1 \\
G. lotoides (New World) & 0 & 1 & 0 & 0 & 0 & 0 & 0 & 0 & 0 & 0 & 0 & 0 & 0 & 0 & 1 & 0 & 0 \\
G. ononoides & 0 & 1 & 1 & 0 & 0 & 1 & 1 & 0 & 0 & 1 & 1 & 0 & 0 & 0 & 0 & 0 & 0 \\
G. oppositifolius & 0 & 0 & 0 & 0 & 1 & 0 & 1 & 0 & 0 & 1 & 0 & 0 & 1 & 0 & 1 & 1 & 1 \\
G. orygioides & 2 & 0 & 1 & 0 & 1 & 0 & 0 & 1 & 1 & 1 & 2 & 0 & 2 & 1 & 2 & 1 & 1 \\
G. radiatus & 0 & 1 & 0 & 0 & 0 & 1 & 1 & 0 & 0 & 0 & 0 & 0 & 0 & 0 & 0 & 0 & 0 \\
G. sessiliflorus & 0 & 0 & 0 & 0 & 0 & 0 & 1 & 0 & 0 & 1 & 0 & 0 & 1 & 0 & 1 & 1 & 1 \\
G. setiflorus & 0 & 1 & 0 & 1 & 0 & 0 & 0 & 1 & 1 & 1 & 1 & 1 & 2 & 1 & 1 & 1 & 1 \\
G. zambesiacus & 0 & 1 & 0 & 0 & 1 & 0 & 1 & 1 & 1 & 2 & 2 & 0 & 1 & 0 & 1 & 1 & 1 \\
\hline
\end{tabular}
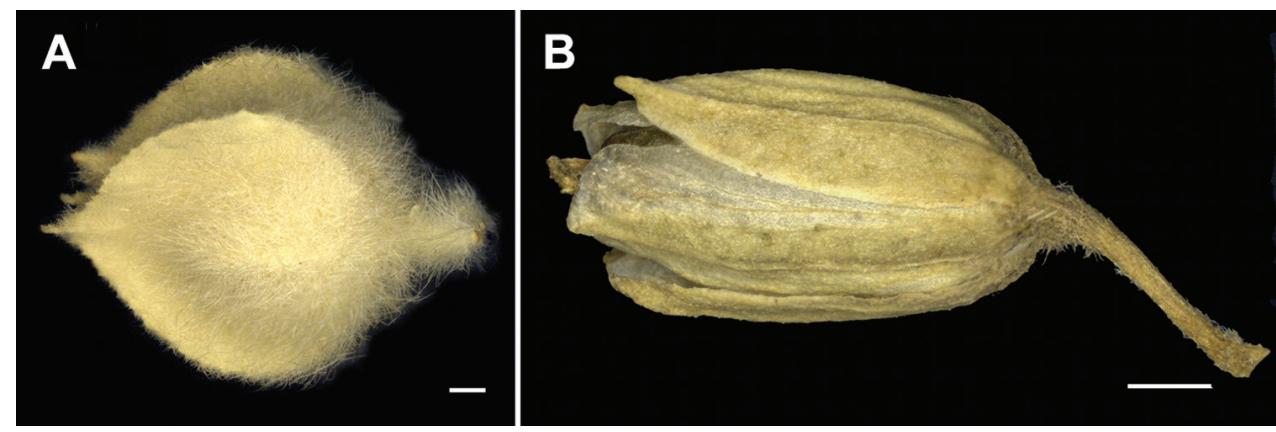

Figure 5. Closed anthocarp of Glinus species A G. setiflorus B G. zambesiacus. Scale bar: $1 \mathrm{~mm}$.

14. Seed length: $0.35-0.60 \mathrm{~mm}(0) ; 0.7-0.9 \mathrm{~mm}(1)$.

15. Seed ultrasculpture (Fig. 6-9): seeds smooth or with barely noticeable colliculae $(0)$; seeds without ridges, only with colliculae (1); seeds with concentric ridges and colliculae (2) (Figs 6A, B, 8G, H).

Note. Two seed types were observed in $G$. hirtus: seeds with smooth surface found in several specimens only (Fig. 6C, D) and more common colliculate ones (Fig. 6E, F). The colliculate ultrasculpture is the most common type in almost all species and their varieties (Figs 6E, F, 7A-D, 8A-F, 9C-H). All Glinus radiatus samples have a smooth seed surface (9A, B), as well as those of $G$. ononoides (Fig. 6G, H) and some specimens of $G$. hirtus (Fig. 6C, D).

16. Stalactites in the testa (Fig. 10): not well-visible (0); prominent (1).

17. Thickness of the seed-coat testa: thin (up to $8 \mu \mathrm{m})(0)$; thick (10-30 $\mu \mathrm{m}$, the thickest area is collicula) (1).

Note. Due to the presence of the colliculae making the seed coat more robust in these areas, the thickness of the seed coat was measured between them. 


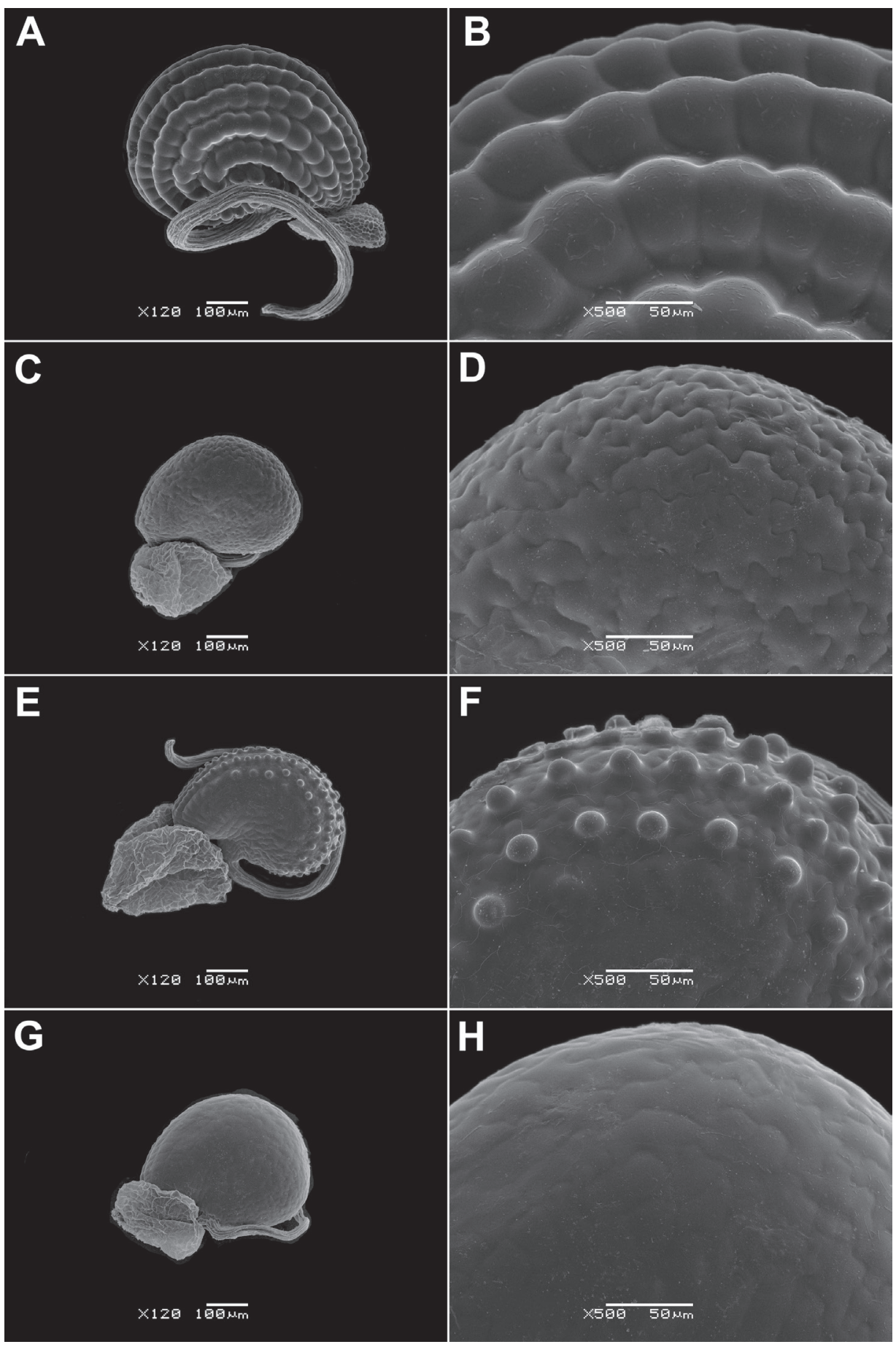

Figure 6. Seeds of Glinus species A, B G. bainesii (Botswana, B. Farrington et al. 486, K) C, D G. hirtus, a form with smooth seeds (Senegal, Perrottet 373, G) E, F G. hirtus, colliculate seeds (DR Congo, Nsimundele 2060, BR) G, H G. ononoides (India, D. Freyn s.n., G). Magnification: $120 \times(\mathbf{A}, \mathbf{C}, \mathbf{E}, \mathbf{G})$; $500 \times(\mathbf{B}, \mathbf{D}, \mathbf{F}, \mathbf{H})$. 


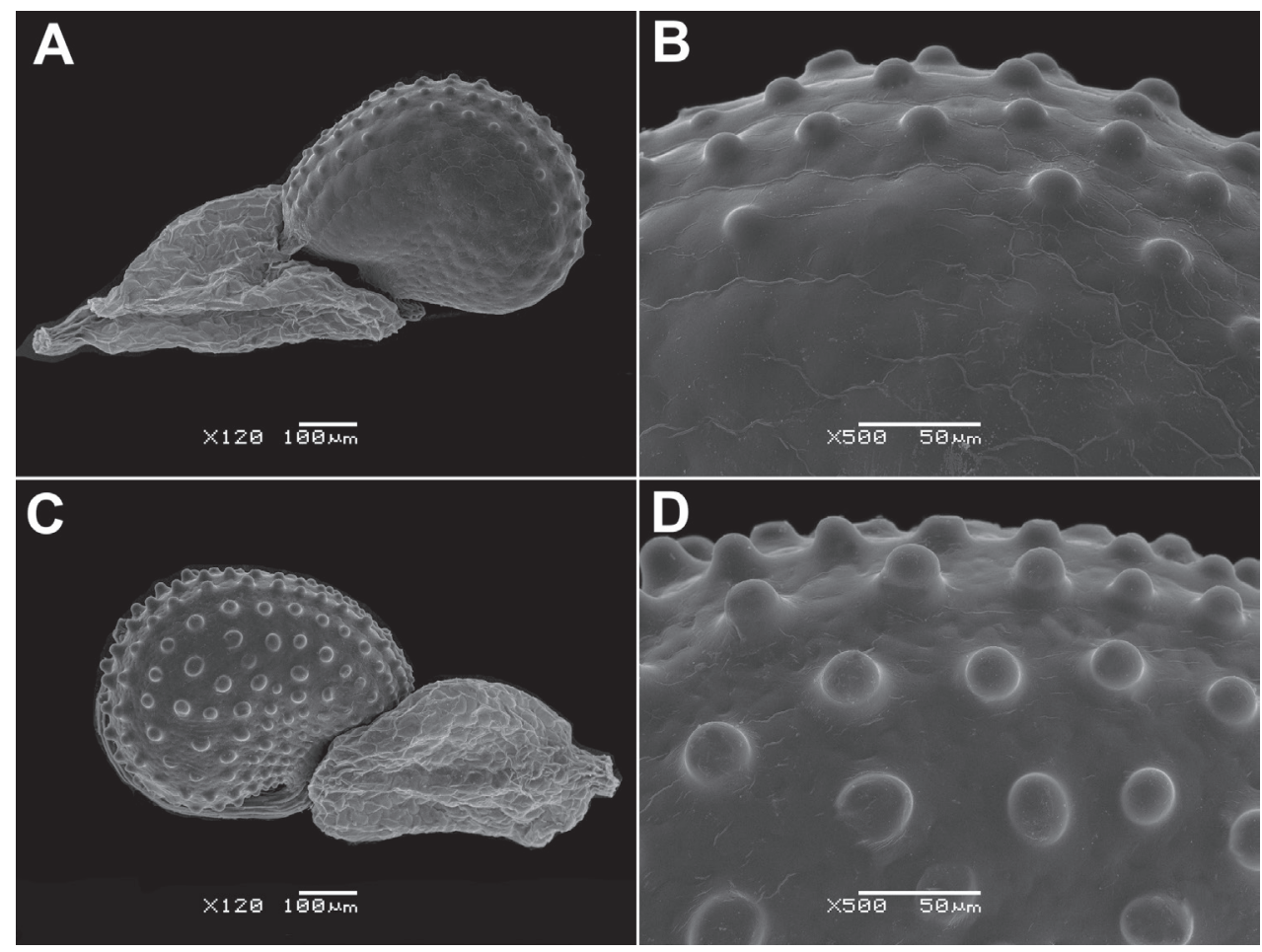

Figure 7. Seeds of Glinus species A, B G. lotoides (Israel, T. Kushnir s.n., HUJ) C, D G. dictamnoides (Kenya, P.R.O. Bally 2679, G). Magnification: $120 \times($ A, C); 500× (B, D).

\section{Multivariate analysis}

The data of the multivariate analysis were evaluated using the matrix of the characters and their states provided in the Table 5 . The results of cluster analysis of all characters suggest the existence of four significantly different groups within Glinus, these branches are highlighted in black (Fig. 11): (1) G. bainesii + G. orygioides (2) G. setiflorus (3) G. lotoides (Old World) + G. dictamnoides, (4) G. radiatus / G. lotoides (New World) + G. zambesiacus + G. hirtus / G. oppositifolius. The groups are significantly $(\mathrm{p}<0.05)$ distinct on different levels of Gower's index.

The first group, G. bainesii and G. orygioides, share 13 characters states, and two of them $(3: 1,15: 2)$ are unique and not known in other Glinus species. Glinus lotoides from the Old World, G. dictamnoides and G. setiflorus (groups 2 and 3) show morphological similarity based on 15 characters $(1: 0,2: 1,3: 0,4: 1,5: 0,6: 0,7: 0,8: 1,9: 1,10: 1,12: 1$; $13: 2,15: 1 ; 16: 1 ; 17: 1)$. The highest number of the same character states (16 out of 17) is detected in the third group $G$. lotoides (specimens from the Old World) - G. dictamnoides. The fourth group unites the species with different character states, and only two of them (1:0 and 3:0) are the same for each species. Within this group, 13 character states are shared between $G$. radiatus and the American populations of $G$. lotoides, and between G. hirtus and G. oppositifolius. Glinus zambesiacus shares 10 character states (1:0, 3:0, 4:0, 7:1, 12:0, 13:1, 14:0, 15:1, 16:1, 17:1) with both G. hirtus and G. oppositifolius. 


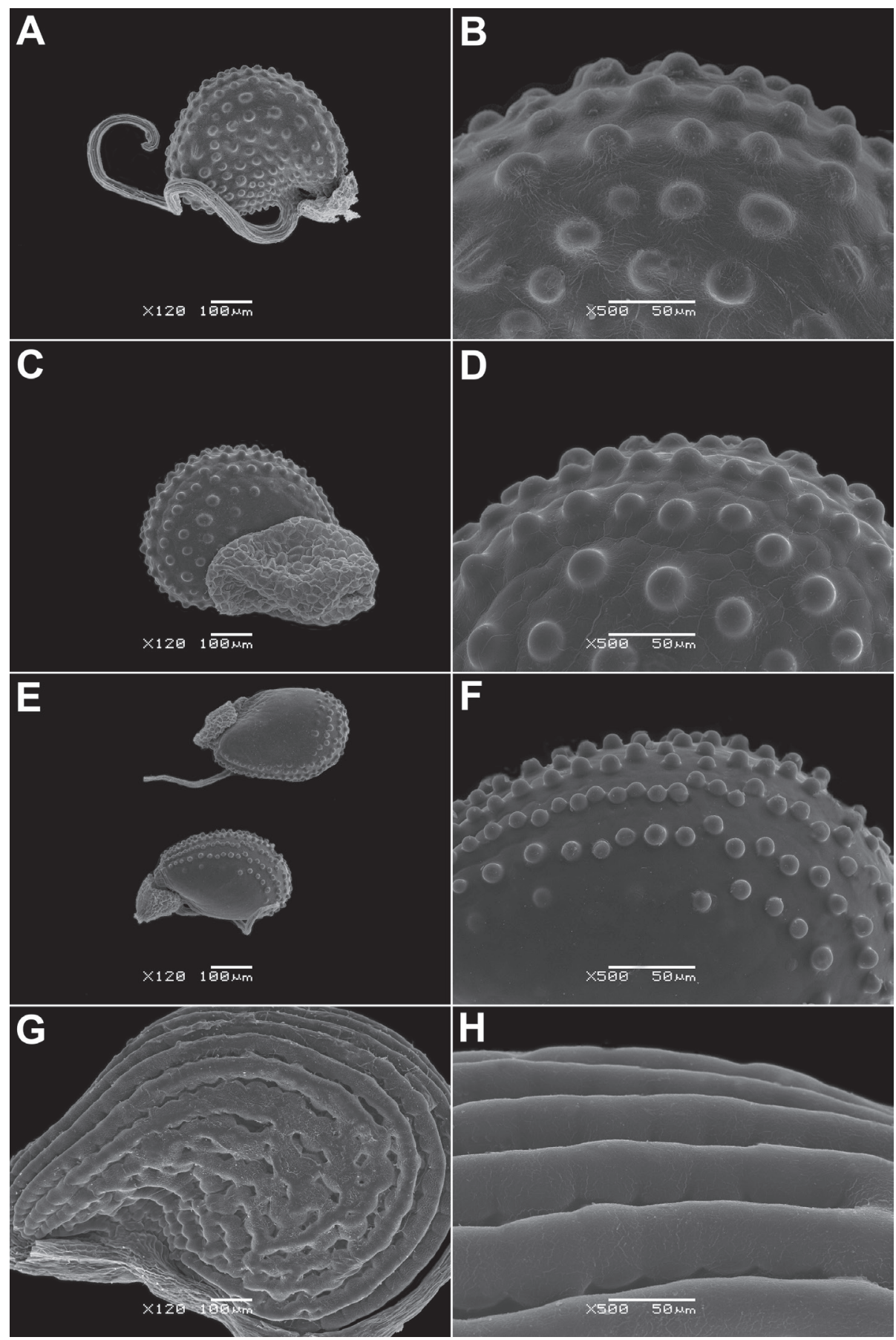

Figure 8. Seeds of Glinus species A, B G. oppositifolius (Zambia, R.B. Drummond \& A.J.Cookson 6335, E) C, D G. oppositifolius var. glomeratus (Angola, E.J. Mendes 3155, M) E, F G. oppositifolius var. keenanii (DR Congo, R. Verschueren 203, BR) G, H G. orygioides (Australia, M.J. Thorpe et al. 119, K). Magnification: $120 \times(\mathbf{A}, \mathbf{C}, \mathbf{E}, \mathbf{G}) ; 500 \times(\mathbf{B}, \mathbf{D}, \mathbf{F}, \mathbf{H})$. 


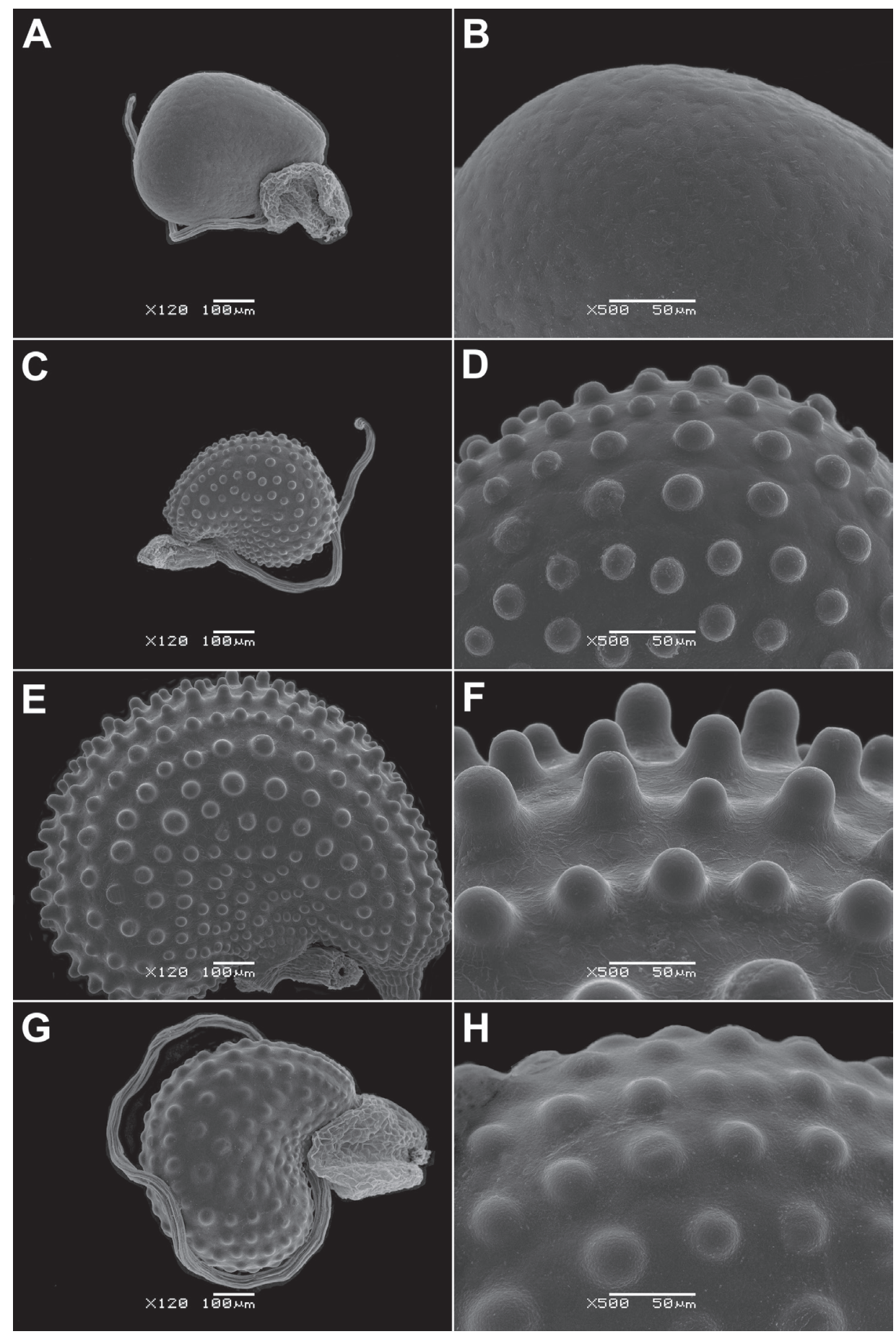

Figure 9. Seeds of Glinus species A, B G. radiatus (Venezuela, A. Fernández et al. 27692, G) C, D G. sessiliflorus (Australia, B.J. Lepschi \&. J.R. Connors 4854, W) E, F G. setiflorus (Ethiopia, G. Popov 1143, K) G, H G. zambesiacus (Zambia, Robinson 6780, M). Magnification: $120 \times(\mathbf{A}, \mathbf{C}, \mathbf{E}, \mathbf{G}) ; 500 \times(\mathbf{B}, \mathbf{D}, \mathbf{F}, \mathbf{H})$. 

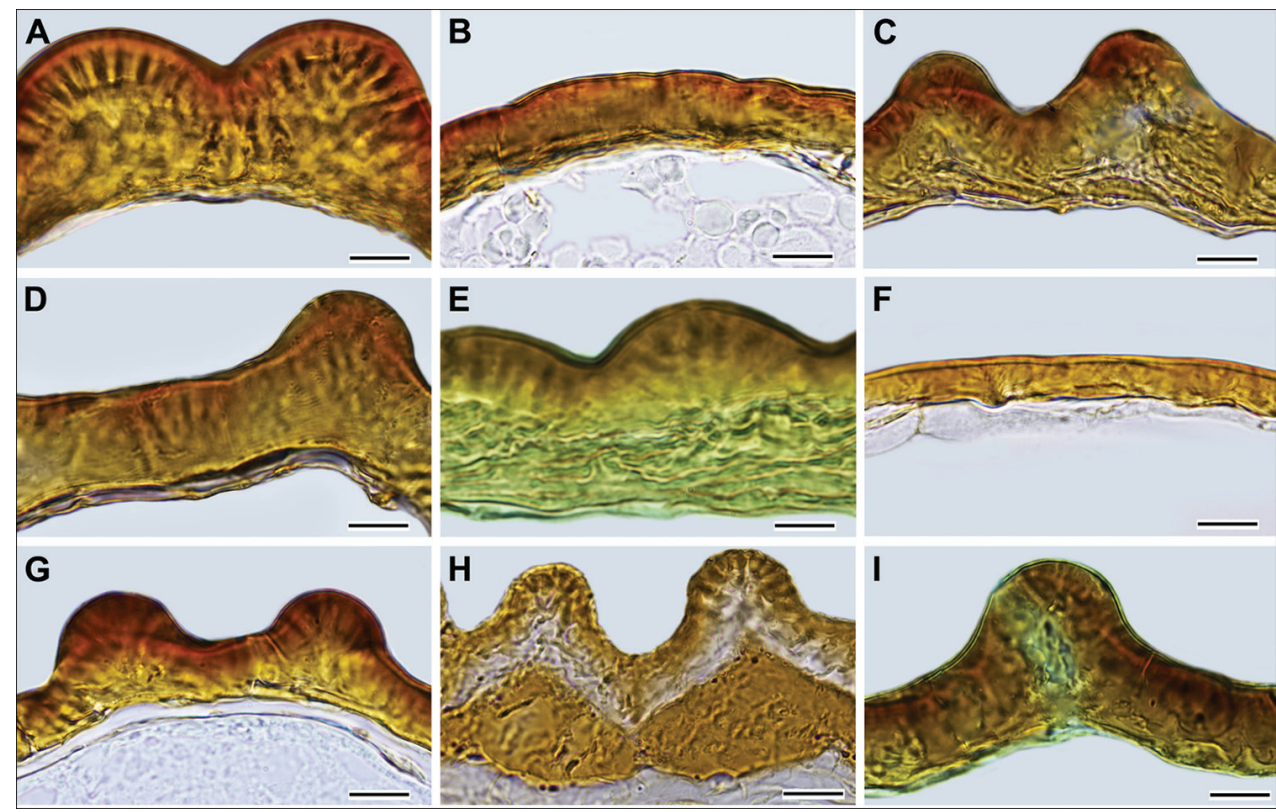

Figure I 0. Seed coat cross-sections A G. bainesii B G. hirtus C G. lotoides D G. oppositifolius $\mathbf{E}$ G. orygioides $\mathbf{F}$ G. radiatus $\mathbf{G}$ G. sessiliflorus $\mathbf{H}$ G. setiflorus I G. zambesiacus. Scale bar: $10 \mu \mathrm{m}$. Glinus dictamnoides has the same seed coat structure as $G$. lotoides and is not illustrated here. Origin of the material is provided in the Table 4 and is designated with an asterisk $\left(^{*}\right)$.

\section{Discussion}

\section{Morphological interpretation of the phylogenetic results}

Monophyly of Glinus is not surprising because all species share the same unique trait (presence of seed aril) not encountered in other genera of Molluginaceae. Mollugo s.str. was suggested to be closely related to Glinus after the first molecular studies (Christin et al. 2011; Thulin et al. 2016), but this is only partially supported by our results. The merging of Glinus into Mollugo s.l. previously undertaken by several authors (e.g., Bentham in Bentham and Mueller 1866; Oliver 1871; Trimen 1894; Clifton 2003) cannot be accepted, even though species of both Mollugo and Glinus share similar morphological and carpological characters, e.g., whorled leaves, leafy inflorescences, multiseeded capsules, colliculate seeds with a relatively thick seed coat with stalactites. The carpological differences between the related genera were determined by Sukhorukov et al. (2018) based on an extended seed analysis.

The major clades of Glinus do not possess distinct morphological characters. None of the peculiar character states provided in Table 5 are known in G. bainesii and $G$. oppositifolius, the earlier diverging lineages of Glinus. Nevertheless, both species share 9 out of 17 character states $(2: 0,4: 0,5: 1,6: 0,7: 1,12: 0,14: 0,16: 1,17: 1)$. The longitudinally ridged seeds of $G$. bainesii are absent in $G$. oppositifolius and almost all 
G. lotoides

(New World)

G. radiatus

G. zambesiacus

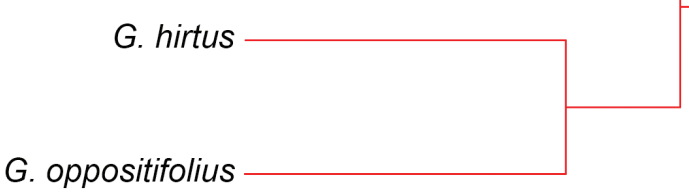

G. setiflorus

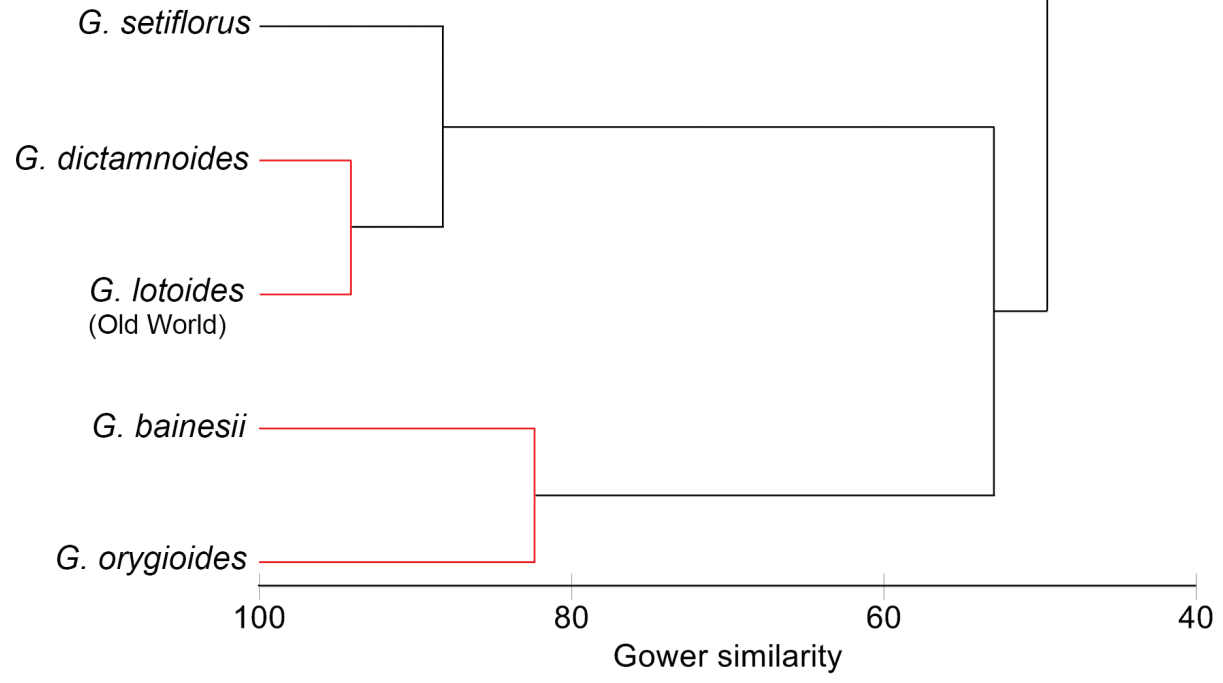

Figure I I. Classification of Glinus species by group average linkage algorithm of cluster analysis based on 17 characters. Black branches connect significantly $(\mathrm{P}<0.05)$ different groups, red branches - insignificantly different groups.

other species except in the phylogenetically distant $G$. orygioides. Seeds with concentric ridges and colliculae (character state 15:2) are rather common in many Mollugo s.str. (Sukhorukov and Kushunina 2017).

The close relationship between the Australian G. orygioides and G. hirtus is unexpected from a morphological point of view. These species share only five character states (4:0, 10:1, 12:0, 16:1, 17:1). Compared with other Glinus species, G. orygioides differs by being a subshrub, while $G$. hirtus has no peculiar character states. Surprisingly, G. hirtus shares eleven character states (mostly gross morphological) with the unrelated $G$. radiatus. From the six states distinguishing these two taxa, only one (seed 
colour) is visible to the naked eye; however, some $G$. hirtus specimens have yellow seeds (13:0), a usual character state in $G$. radiatus. The other five character states are micromorphological (length of anthers and stylodia, seed ultrasculpture, presence of stalactites in the testa and its thickness). This similarity in the gross morphology has caused the misidentification of both species.

The results of the molecular analysis support the polyphyly of G. lotoides; a sample from the New World forms a clade together with G. radiatus. The specimens of American $G$. "lotoides" seen by us have yellow or bright brown seeds, like G. radiatus (not dark red or almost black as in G. lotoides s.str.: state 13:2 in the Table 5), and differ from it by colliculate seed sculpture (e.g., Thieret 1966) and larger perianth segments (Christy 1998). We provisionally accept only one native species in the Americas (G. radiatus s.l.). The close relationship between the Old World G. lotoides specimens and $G$. setiflorus is supported by many identical character states (Table 5; Figs 7A-D, 10C, H), and they both share nine states with $G$. zambesiacus. In the absence of a well-resolved relationship between $G$. lotoides and $G$. dictamnoides in the plastid and nuclear gene trees, we suggest that $G$. dictamnoides be treated as a synonym to $G$. lotoides, as was proposed in the earlier studies (e.g. Backer 1951; Zohary 1966; Hassan et al. 2005).

Due to the discordance between the gene trees and multivariate analysis of morphological characters, we cannot propose any infrageneric groups within Glinus. We assume that character states shared between phylogenetically distant taxa should be interpreted as homoplasies. Similarly, the former genus subdivision proposed by Endlicher (1840) and based on the pubescence details is also not supported.

\section{Biogeography}

Both the plastid and nuclear gene trees suggest that Glinus started to diversify during the Neogene. Even though our results do not indicate a clear origin of Glinus, it seems to be connected to Africa (Fig. 4). Origin and adaptation to Neogene aridification in Africa has also been reported in many other plant lineages such as Acridocarpus Guill. \& Perr., Malpighiaceae (Davis et al. 2002), Coccinia Wight \& Arn., Cucurbitaceae (Holstein and Renner 2011), Guibourtia, Fabaceae (Tosso et al. 2017), Manilkara Adans., Sapotaceae (Armstrong et al. 2014) and the tribe Melastomateae, Melastomataceae (Veranso-Libalah et al. 2018). The Australian Glinus orygioides and the American $G$. radiatus group probably originated during the Late Miocene and Pliocene based on the plastid and nuclear gene trees, respectively. Long-distance dispersal might be the most appropriate explanation for migration of the species to Australia and America during the Neogene.

\section{Extant geographical distribution}

Two species from the basal clade(s) - G. oppositifolius and G. bainesii - prefer different climates. Glinus bainesii is well adapted to the hot semi-arid climate [climate classification used here is according to Köppen (1936), with additions by Geiger (1961)]. 
Glinus oppositifolius is more frequently found in regions with tropical rainforest and savanna climates. In the regions with hot semi-arid or desert climates, it clearly prefers the habitats near water sources (e.g., river banks). Another widely distributed species, $G$. lotoides, as well as East African G. setiflorus, are drought-adapted species and avoid territories with tropical rainforest and monsoon climates.

Altogether, we accept 9-10 species in (sub)tropical parts of the World. These can thrive in different habitats (riversides, deserts, stone outcrops, sandy coastal areas) and sometimes are noxious weeds, especially in the tropics with a humid climate. The species number is unevenly distributed around the World (Fig. 12). Four species occur in Australia ( $G$. lotoides, $G$. oppositifolius, $G$. sessiliflorus and $G$. orygioides, endemic to N \& C Australia: Short 2002, 2011), with the northern regions being the most speciesrich. The Americas are reported to have two species: G. lotoides, considered to be an alien from the Old World, and G. radiatus (Grayum and Koutnik 1982; Boetsch 2002; Vincent 2003; Vigosa Mercado 2015). However, the presence of G. lotoides in the New World is doubtful. Further taxonomic studies are needed to decide whether the carpological and chorological data support the acceptance of the second (presumably native) Glinus species in North America. The species number in Asia is two or three: poorly known Indian $G$. ononoides with only two old collections seen by us (G! K!), $G$. lotoides and G. oppositifolius (e.g., Backer 1951; Hedge and Lamond 1975; Heller and Heyn 1994; Lu and Hartmann 2003; Townsend 2016; Byalt and Korshunov 2020) with synonyms or insufficiently studied taxa described from Asia (see Taxonomic section below). Only one species (G. lotoides) is present in S Europe (Paradis 1993; Tutin et al. 1993) as well as in North Africa (Maire 1962; Boulos 1999). On the contrary, the Sub-Saharan area incorporates two to six species, depending on the regions (Fig. 12). The most species-rich region (5 spp.) is East Africa (Kenya and Tanzania). A large region with a tropical savanna climate is the second richest region with four species.

\section{Possible mode of species dispersal}

All Glinus species have hydrochastic capsules which open when triggered by rain drops (ombrohydrochory). This seems to be a somatic response of the plants to the climates characterized by alternating dry and wet periods. It is also known in many members of the Aizoaceae (Parolin 2006; Kurzweil and Burgoyne 2009) from areas with hot desert and semi-arid climates. In light of the presumable African origin of Glinus, such disseminative adaptation allows for a rapid seed dispersal during the rainy season.

In all species of the genus, the dispersal unit is a seed. The rains enable rapid dehiscence of the capsules and further dispersal of the seeds with surface water runoff. Additionally, the dry seeds due to their tiny size can easily roll over the substrate (Sulakshana and Raju 2018). However, it is unlikely that the seeds can move long distances in this manner, and, at least in $G$. lotoides, they remain viable only for several months (Bhatia 1987; Teshome and Feyissa 2015). We suggest that epizoochory may play a significant role in the dissemination, whereby moist substrate particles with seeds attached may inadvertently be carried by animals or humans. 


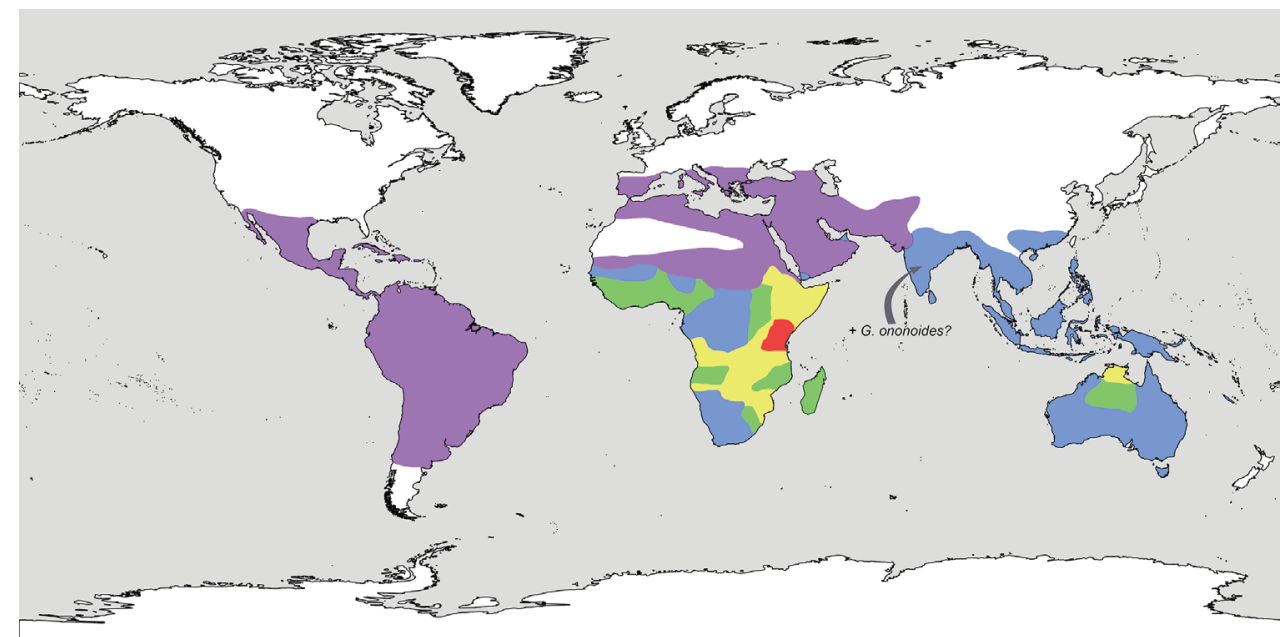

Figure I 2. The number of Glinus species around the world. Areas coloured in mauve - one species, blue - two species, green - three species, yellow - four species, red - five species. Area boundaries are approximated. G. ononoides is a poorly known Indian taxon that needs to be studied further.

\section{Taxonomic treatment of Glinus in Sub-Saharan Africa}

The following treatment provides a new insight into the identification, taxonomic composition and distribution of Glinus in Sub-Saharan Africa where the genus is represented by 6 species.

\section{Genus Glinus L., Sp. Pl. 1: 463 (1753).}

三Mollugo sect. Glinus (L.) Benth. in Benth. \& Mueller, Fl. Austr. 3: 333 (1866).

$\equiv$ Rolofa Adans., Fam. Pl. 2: 256 (1763), nom. illeg.

Type: Glinus lotoides L.

= Physa Touars, Gen. Nov. Madagasc.: 20 (1806).

Type: Physa madagascariensis DC., Prodr. 1: 393 (1824) (= Glinus oppositifolius (L.) Aug.DC.)

= Plenckia Raf., Specch. 1: 194 (1814), nom. rej.

Type: Plenckia setiflora (Forssk.) Raf. (三 Glinus setiflorus Forssk.).

= Tryphera Blume, Bijdr. Fl. Ned. Ind. 11: 549 (1826).

Type: Tryphera prostrata Blume, Bijdr. Fl. Ned. Ind. 11: 549 (1826) (= Glinus oppositifolius (L.) Aug.DC).

= Wycliffea Ewart \& A.H.K.Petrie, Proc. Roy. Soc. Victoria n.s. 38: 167 (1926).

Lectotype (designated here): Wycliffea obovata Ewart \& A.H.K.Petrie, Proc. Roy.

Soc. Victoria n.s. 38: 167 (1926). 
Description. Annual, rarely perennial, prostrate herbs or erect subshrubs with a rootstock, covered with stellate or simple (multiseriate, soft and crispate) hairs, in the latter case additionally with multiseriate, stout thick-walled and broad-based hairs (prickles). Stems branched from the base, often forming mats, rarely erect ( $G$. orygioides). Leaves in false whorls, lanceolate to obovate, entire or denticulate (mostly in their upper half), with several lateral nerves that can be adaxially recessed and abaxially prominent. Flowers usually several to many (up to 20) in leaf axils forming loose or rarely dense inflorescences, bracteate, sessile or pedicellate. Perianth of 5 free oblong, ovate or roundish segments, green (brown) abaxially and white, pinkish or yellowish adaxially, with a green or brown midvein, horizontally spreading when fully opened, sometimes white petaloid staminodes present, always shorter than perianth segments. Stamens (2-4)5-30, outer stamen series corresponding to another staminode whorl (if stamen number is more than 5) often with filaments terminating with teeth (and without anthers), 0.3-1.8 mm, oblong or roundish; anthers yellow; pollen tricolpate (studied in G. lotoides: Perveen and Qaiser 2000). Stylodia 3-5, free or united in lower half into a style. Anthocarp (fruit enclosed by perianth) cylindrical or ovate to roundish. Fruit a hydrochastic loculicidal capsule. Ovary three- or five-carpellate, ovules arranged in two rows. Seeds usually more than 50, yellow, red, brown or black, up to $1.0 \mathrm{~mm}$ long, ovoid or reniform, smooth or with numerous colliculae; seed aril divided into two parts: a white, very noticeable hood covering the funiculus and a large ribbon-like appendage, sometimes the hood is reduced. Embryo curved; perisperm abundant and easily visible (in larger seeds) or scanty (in small seeds).

The basic chromosome number in G. radiatus is x = 9 (Lane and Keil 1976), which corresponds with that of other Molluginaceae (Bogle 1970, with references therein). However, Mitra and Datta in Löve (1967) indicated the basic number x = 18 for the Indian populations of Glinus lotoides and G. oppositifolius.

\section{Artificial key to the Glinus species in sub-Saharan Africa based on gross mor- phology}

1 Plants glabrous or with simple (sometimes additionally with prickle-like) hairs mostly localized in young plant parts ................................................ 2

- Plants covered with stellate hairs .............................................................. 3

2 Stems, sometimes leaf petioles and perianth segments with tiny (up to $0.5 \mathrm{~mm}$ ) stout prickle-like hairs; perianth segments in fruiting 7.0-9.0 mm long; stamens more than 10; anthers 1.3-1.5 mm long; seed surface with longitudinal ridges bearing colliculae G. bainesii

- All plant parts without stout prickle-like hairs, or such hairs almost unnoticeable; perianth segments in fruiting up to $5.0(5.5) \mathrm{mm}$ long; stamens (3)5(7); anthers up to $1.0 \mathrm{~mm}$ long; seed surface smooth or with colliculae, but in latter case without longitudinal ridges.

3(1) Plants white to grayish-green due to abundant stellate hairs; leaves obovate, broadly obovate or roundish, their veins adaxially recessed and abaxially prominent; 
flower buds or anthocarp (capsules with the closed perianth) ovoid or roundish, 5.0-12.0 × (3.0)3.5-9.0 mm; stigmas usually 5; seeds dark red to black ........... 4

- Plants green; leaves narrowly oblong to obovate, veins neither recessed nor prominent; flower buds and anthocarp cylindrical, 3.0-7.0 × 2.0-3.0 mm; stigmas 3; seeds reddish or brown-red..................................................................... 5

4 Glomerules of (1)2-4 flowers; perianth in fruiting 8.0-12.0 mm long; seeds 0.7$0.9 \mathrm{~mm}$ long; funicular hood often reduced.... G. setiflorus

- Glomerules of 4-12 flowers; perianth in fruiting 5.5-8.5 mm long; seeds 0.5-0.6 $\mathrm{mm}$ long; funicular hood easily visible G. lotoides

5(3) Flowers sessile or with short pedicels up to $3.0(4.0-5.0) \mathrm{mm}$; perianth in fruiting (3.5)4.0-5.0(5.5) mm long; stamens (3-4)5(6-8); anthers 0.6-0.9 mm long; seeds $(0.35) 0.40-0.50 \times 0.25-0.30 \mathrm{~mm}$.

G. hirtus

- Flowers with well-developed pedicels 5-20 mm long, rarely 2-5 mm long; perianth in fruiting 6.5-8.0 mm long; stamens more than 10; anthers (1.0)1.2-1.8 $\mathrm{mm}$ long; seeds $0.5-0.6 \times 0.35-0.50 \mathrm{~mm}$

G. zambesiacus

\section{List of accepted species in Sub-Saharan Africa (arranged alphabetically)}

\section{Glinus bainesii (Oliv.) Pax, Nat. Pflanzenfam. 3(1b): 40 (1889).}

इ Mollugo bainesii Oliv., Fl. Trop. Afr. 2: 590 (1871).

Type: [BOTSWANA, North-West distr.] "Koobie [Chobe] to N.[orton] Shaw valley, Jan-Mar 1863, T. Baines [s.n.]” (K000232022!).

Note. (1) The so-called "Norton Shaw valley" lies close to Ngami Lake (Passarge 1904), and "Koobie" should be applied to "Chobe"; (2) The type specimen indicated by Adamson (1961) as kept at GRA is absent in this herbarium (Tony Dold, pers. comm.).

Description.(Fig. 13A-G). Annual or perennial, prostrate or ascending, up to 12 $\mathrm{cm}$ tall, often forming large mats up to $1.5 \mathrm{~m}$ in diameter. Stems covered with simple crispate hairs; stems, peduncles and sometimes leaf petioles and midveins additionally covered with small, stout hairs (prickles). Leaves rosulate, short-lived, and cauline, green, stout, entire, $10.0-17.0 \times 2.0-4.0 \mathrm{~mm}$, oblanceolate or narrowly oblong, sessile or short-petiolate (petioles up to $3.0 \mathrm{~mm}$ ), mucronulate, veins neither recessed adaxially nor prominent abaxially. Flowers in clusters of $2-7$, distant, pedicellate, pedicels $5.0-16.0 \mathrm{~mm}$, in fruiting up to $20.0 \mathrm{~mm}$; buds and closed anthocarp cylindrical. Perianth segments in flowering $6.0-8.0 \mathrm{~mm} \times 2.5-3.0 \mathrm{~mm}(10-16 \mathrm{~mm}$ in diam.), in fruiting $7.0-9.0 \mathrm{~mm}$ long, glabrous or sparsely pubescent, dorsally green or with white margins, ventrally white, creamy, pink or pale mauve. Stamens 10-15, outer stamen series (petaloids) sterile, with filaments terminating in teeth; anthers $1.3-1.5 \mathrm{~mm}$ long. Stigmas 3, $-1.2 \mathrm{~mm}$ long. Seeds $0.6 \times 0.5 \mathrm{~mm}$, almost black, with longitudinal ridges carrying colliculate cells; aril hood clearly visible, $0.25 \mathrm{~mm}$ long.

Remarks. In the herbaria G. bainesii (Fig. 14) is often confused with G. oppositifolius, but it is differentiated from the latter species by having small prickles, larger perianth and anthers, and seeds with longitudinal ridges (Table 5). 

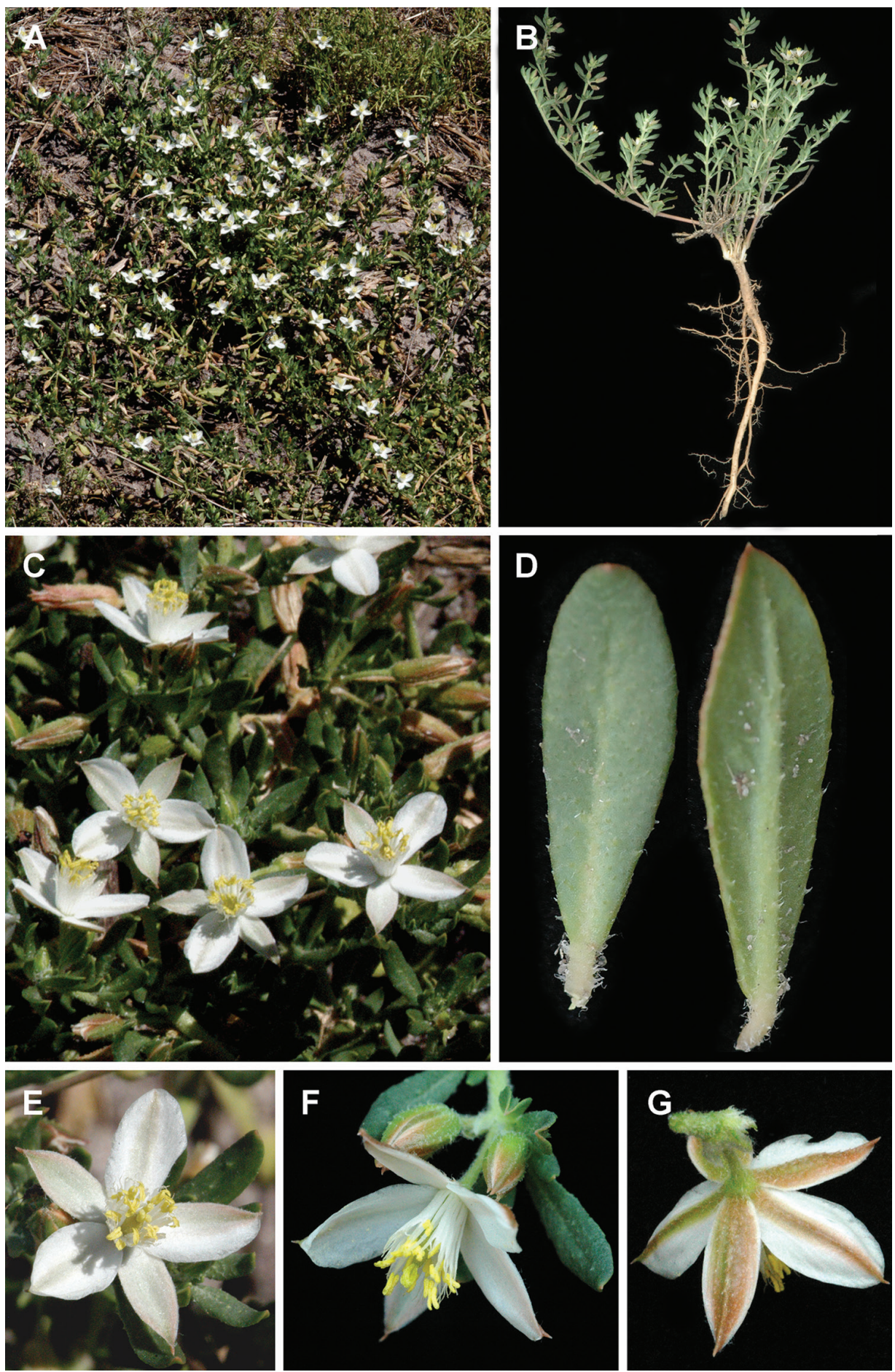

Figure 13. Glinus bainesii A, B an overview of the plant $\mathbf{C}$ flowers $\mathbf{D}$ leaves $\mathbf{E}-\mathbf{G}$ close-up of individual flowers. Photographers - Roger and Alison Heath (A, C, E Okavango Delta, Ngamiland, Botswana, 28 Nov 2004 B, D, F, G Moremi Game Reserve, Ngamiland, Botswana, 21 Nov 2007). 


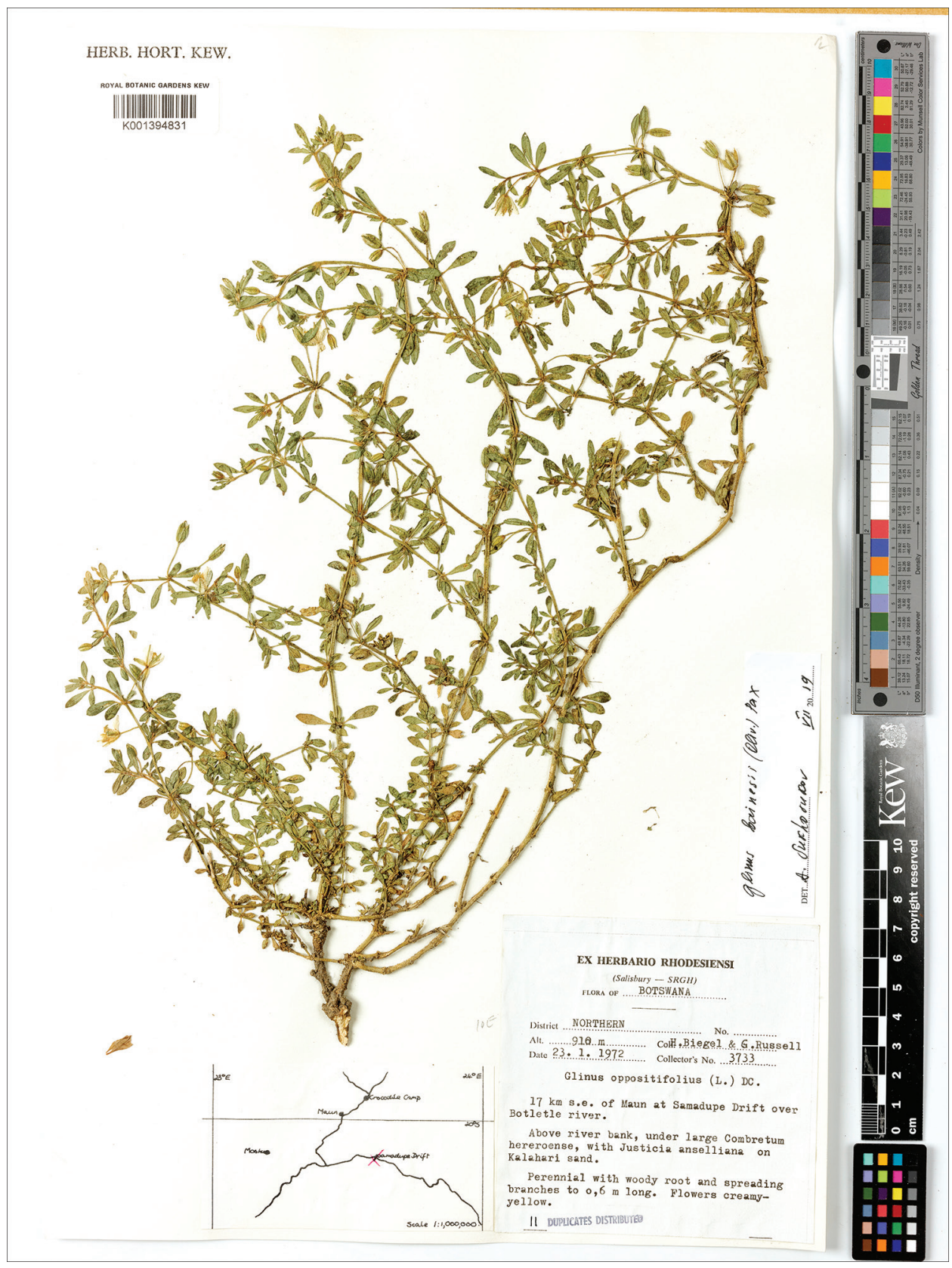

Figure 14. A herbarium specimen of Glinus bainesii (Botswana, Northern distr., $17 \mathrm{~km} \mathrm{SE}$ of Maun at Samadupe drift over Botletle river, 23 Jan 1972, H. Biegel \& G. Russell 3733, K001394831). Copyright of the Board of Trustees of the Royal Botanic Gardens, Kew.

Habitat. Riverbed sands, flat flood plains, margins of muddy seasonal pans, sparsely vegetated areas at elevations $0-1200 \mathrm{~m}$ a.s.l. Associated plants found in Botswana: Dicerocaryum eriocarpum, Pterococcus oppositifolius var. oppositifolius, poor soil 


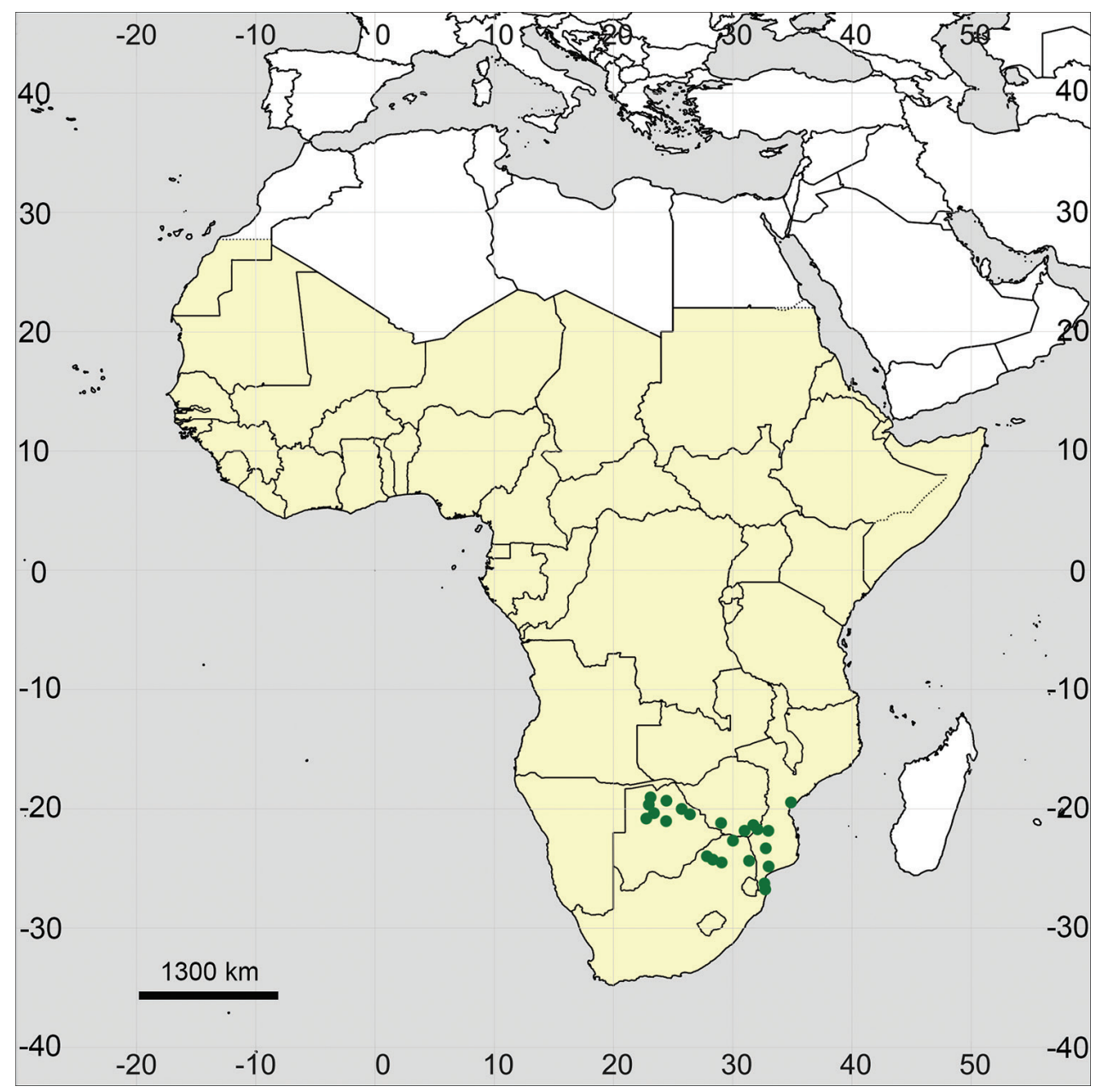

Figure I5. Distribution map of Glinus bainesii in Sub-Saharan Africa (coloured in yellow).

Cypreaceae and Poaceae spp. (A. Heath \& $R$. Heath 734, K); Fuirena pubescens, Neptunia oleracea, Hibiscus meeusei, Cyperus compressus, Senna obtusifolia (A. Heath \& $R$. Heath 428, K); Vahlia capensis, Heliotropium ovalifolium, Cynodon dactylon, Streptoglossa decurrens, Jamesbrittenia elegantissima (A. Heath \& $R$. Heath 1417, K). Flowers during both the early and the main rains.

Distribution (Fig. 15). Botswana: Ngamiland, Kwebe Hills, 3300 ft, 4 Feb 1898, E.J. Lugard $152(\mathrm{~K})$; Northern Bechuanaland, Sigere pan, 30 miles W of mouth of Nata river, 896 m, 25 Apr 1957, Drummond \& Seagrief 5216 (K); Ngamiland, Sehitwa, Lake Ngami, 930 m, 25 Mar 1961, H.M. Richards 14849 (K); Northern distr., $17 \mathrm{~km}$ SE of Maun at Samadupe drift over Botletle river, 23 Jan 1972, H. Biegel \& G. Russell 3733 (BR0000017454490, K001394831, M, P04577251); Northern distr., Moremi reserve, $19^{\circ} 10.4^{\prime}$ S, 23⒖7'E, 26 Jan 1974, P.A. Smith 848 (B101143636, K, WAG1103318); Northern distr., Nata river delta, 21 Apr 1974, J.F. Ngoni 529 (K, PRE0825248); Ngami Lake, 13 Dec 1982, P.A. Smith 3981 (BR0000017454506, 
E, K); between Motswiri and TFC [Tsetse Fly control] road, $18^{\circ} 45.671^{\prime} \mathrm{S}, 23^{\circ} 15.033^{\prime} \mathrm{E}$, $966 \mathrm{~m}, 19$ Mar 2003, A. Heath \& $R$. Heath $428(\mathrm{~K}) ; 17 \mathrm{~km} \mathrm{~S}$ of Tsetse Fly control road, $18^{\circ} 45.565^{\prime \prime S} 23^{\circ} 05.208^{\prime \prime E}, 964 \mathrm{~m}, 28$ Nov 2004, A. Heath \& $R$. Heath $734(\mathrm{~K})$; Khwai River floodplain, Moremi Game Reserve, 19¹0.505'S, 23⒋176'E, 940 m, 21 Nov 2007, A. Heath \& $R$. Heath 1417 (K); Ngamiland, $100 \mathrm{~m} \mathrm{~S}$ of Samudupe bridge, 206'59"S, 2331'38"E, 938 m, 19 Feb 2008, B. Farrington et al. 486 (K);

Mozambique: Lorenço Marques [Maputo], 7 Dec 1897, B. Schlechter 11643 (BM, BR0000018267990, E, G, LE, P04577163, WAG1 103122); Sofala [prov.], Nov 1901, Anonymous 2654 (WAG1103309); Lorenço Marques [Maputo], 21 Mar 1920, Berle 761 (B101143603, BR0000018267983, M); Lorenço Marques [Maputo prov.], between Umbeluzi and Porto Henrique, 20 Nov 1940, A.R. Torre 2090 (K); Gaza prov., Aldeira da Barragem, 20 Nov 1957, L.A.G. Barbosa \& F. de Lemos 8222 (K); Gaza prov., Caniçado, 23 Aug 1969, M.F. Correia \& A. Marques 1158 (WAG1103272); Gaza prov., Limpopo, Massangena, 21 Jul 1973, M.F. Correia \& A. Marques 2979 (K, M, WAG1103326); Gaza prov., Caniçado, 6 Aug 1973, M.F. Correia \& A. Marques 3184 (WAG1103323); Lorenço Marques [Maputo prov.], Porto Henrique, Bela Vista, 25 Mar 1975, A. Marques 2670 (WAG1103271); Maputo, 13 Dec 1979, J. de Koning 7754 (BR0000013706678, BM, K);

South Africa: [Limpopo province] Messina [Musina], alt. 2000 ft, Sep 1917, F.A. Rogers 19299a (BM, G); Transvaal [Limpopo prov.], Messina [Musina], 27 May 1927, R.G. Young 18391 (BM); Transvaal prov., Ellisras, 2900 ft, 24 Feb 1954, L.E. Codd 8491 (K, L1698855); Transvaal [Limpopo prov.], Potgietersrust [Mokopane], Doornpoort Farm, 19 Jan 1955, A.D.J. Meeuse 9552 \& 9552a (K, M); Transvaal [Limpopo prov.], Waterberg distr., Tamboetie river, Ellisras-Vila Nova road, 7 Jan 1959, A.D.J. Meeuse \& R.G. Strey 10446 (BM, BOL217406, BRLU0026260, K, M, Z-000092195); Transvaal [Limpopo prov.], Kruger NP, 31 Jan 1962, H. Schlieben 9321 (W20978); Mpumalanga prov., Kruger NP, 26 Nov 2015, G. Zambatis 1195 (PRE0990262);

Zimbabwe: [Masvingo prov.] Sabi-Lundi Junction District, Chiribira Falls, 6 Jun 1950, Wild 3448 (B101143602, BR0000018267976, K); [Matabeleland South prov.] Gwanda Distr., 700 ft, Nov 1956, R.M. Davies 2185 (K); [Masvingo prov.] Nuanetsi, nr Malipate, 2 May 1961, R.B.Drummond \& R.O.B. Rutherford-Smith 7680 (K); [Masvingo prov.] Chiredzi, nr Sabi-Ludi junction, 31 May 1971, S. Mari 1273 (K, LE);

General distribution. Endemic to Zambezi floristic province (according to Takhtajan 1986). Reported from Okavango region, NE Namibia (Friedrich 1966), but the cited specimen ("Lightfoot 65") has not been found by us (SAM?).

\section{Glinus hirtus (Thunb.) Sennikov \& Sukhor., comb. nov.}

urn:lsid:ipni.org:names:77215157-1

三 Mollugo hirta Thunb., Prodr. Pl. Cap. 1: 24 (1794).

三 Pharnaceum hirtum (Thunb.) Spreng., Syst. Veg., ed. 16, 1: 949 (1824). 
三 Glinus lotoides subsp. hirtus (Thunb.) M.R.Almeida, Fl. Maharashtra 2: 342 (1998) (as "hirta").

Lectotype (designated here): South Africa. "E Cap. bon. spei” [Cape of Good Hope], C. Thunberg (UPS-Thunb 2851!; isolectotype UPS-Thunb 2850!).

= Glinus dahomensis A.Chev., Fl. Afrique Occ. Franc. 1: 323 (1938), nom. inval. (Art. 39.1).

Original material: [Benin] Dahomey, Kouandé à Kontobiri entre Quétécou et Firou [from Kouandé to Kontobiri between Quétécou and Firou], 29 Jun 1910, A. Chevalier 24288 (P00461735!).

- Glinus congolanus Hauman in herb. BR.

Description. (Figs 16, 17). Annual, highly branched, with prostrate or ascending stems up to $100 \mathrm{~cm}$ long, covered with stellate (sometimes very scattered) and branched hairs, prickles absent. Leaves rosulate, short-lived, and cauline, green or grayish-green turning red at senescence, sparsely to moderately pubescent, rarely glabrous, petiolate (petioles up to $10.0 \mathrm{~mm}$ ), entire or slightly crisp or scarcely denticulate, ovoid, obovate or oblong-spatulate, $10.0-40.0(45.0) \times 3.0-15.0(18.0) \mathrm{mm}$, acuminate, lateral veins neither recessed adaxially nor prominent abaxially. Flowers in clusters of $8-20$, distant or approximated in the upper part of the inflorescence, $8-13 \mathrm{~mm}$ in diameter, sessile or with short pedicels up to $3.0(4.0-5.0) \mathrm{mm}$; buds and closed anthocarp cylindrical. Perianth segments in flowering $3.0-4.2 \mathrm{~mm}$ long, in fruiting (3.5) $4.0-5.0(5.5) \mathrm{mm}$ long, glabrous or sparsely pubescent, dorsally green or with white margins and ventrally white or mauve; tips \pm recurved at fruiting. Stamens (3-4)5(6-8), sometimes with sterile teeth; anthers 0.6-0.9 mm long. Stigmas 3, 0.5-1.0 mm long. Seeds reddish or brown-red, (0.35)0.40$0.50 \times 0.25-0.30 \mathrm{~mm}$, colliculate or rarely almost smooth, longitudinal ridges absent.

Note. Mollugo hirta described from South Africa was very rarely accepted in old taxonomic literature, and only cited as a poorly known species (Fenzl 1836). Otherwise, it has been commonly considered a synonym of G. lotoides (e.g., Fenzl 1840; Harvey and Sonder 1860; Just 1879; Adamson 1961; Hedge and Lamond 1975; Gonçalves 1978). We state for the first time that (1) Mollugo hirta must be resurrected in specific rank based on both molecular and morphological studies as G. hirtus, and (2) this species is conspecific with the name $G$. dahomensis. Specimens of this species were misidentified in collections with various names, particularly $G$. lotoides, G. lotoides var. virens, G. lotoides $\times$ G. oppositifolius, G. spergula, and Mollugo glinoides (both latter names belong to the synonymy of G. oppositifolius). Almeida (1998) referred the Indian plants to $G$. lotoides subsp. hirtus in the belief that they differ from the European populations ( $G$. lotoides subsp. lotoides), but he did not indicate any differences between them. However, his description of the subspecies rather belongs to G. lotoides based on the number of stamens (>10) and stigmas (5), while G. hirtus has up to eight stamens and three stigmas.

The name $G$. dahomensis was originally introduced (Chevalier 1938) with a description in French, whereas the nomenclatural code required a description or diagnosis in Latin. To date the name $G$. dahomensis remains invalidly published because of having been commonly placed in the synonymy of $G$. lotoides var. virens. 

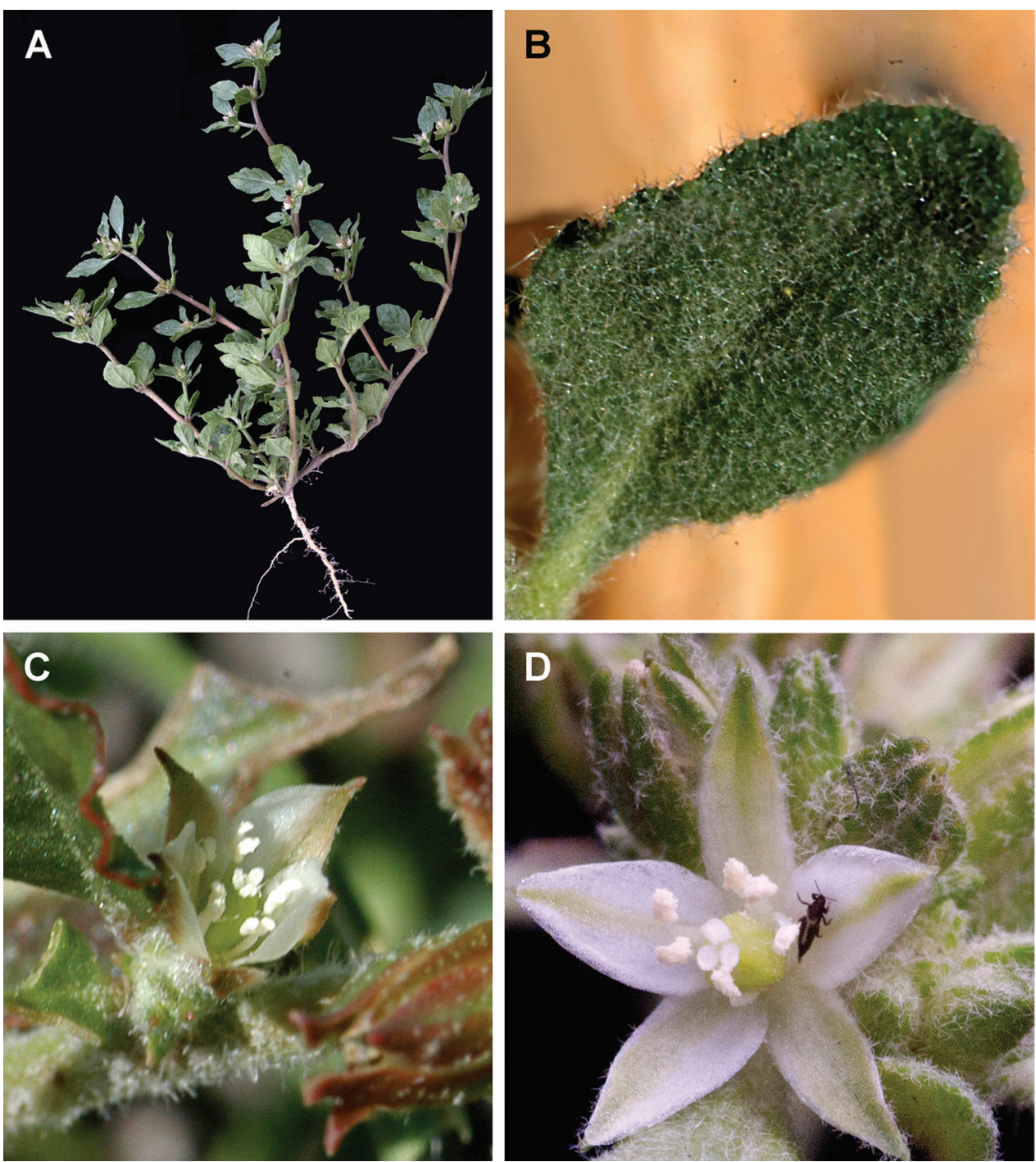

Figure 16. Glinus hirtus $\mathbf{A}$ an overview of the plant $\mathbf{B}$ close-up of the leaf $\mathbf{C}, \mathbf{D}$ flowers. Photographers - Roger and Alison Heath (A, D Moremi Game Reserve, Ngamiland, Botswana, Nov 2010 B, C Selinda, Ngamiland, Botswana, 04 Nov 2004 (B), 23 Jan 2004 (C).

While considering $G$. hirtus distinct from $G$. lotoides, we resurrect the name published by Thunberg because it is the only one available for the species as circumscribed in our study.

Glinus hirtus is morphologically very close to G. ononoides Burm.f. described from India (Burman 1768), a species completely forgotten in the past (Dizionario... 1842) and present. The differences between both species are minor and limited to the following characters: (1) the type of $G$. ononoides has stellate hairs that are mostly localized on the young stem parts and leaves and additionally very short (up to $0.4 \mathrm{~mm}$ ) 




Figure 17. A herbarium specimen of Glinus hirtus (Central African Republic, $300 \mathrm{~m} \mathrm{NW}$ of Gounda, $9^{\circ} 18^{\prime} \mathrm{N}, 21^{\circ} 12^{\prime} \mathrm{E}$, alt. $450 \mathrm{~m}, 28 \mathrm{Jul}$ 1982, J.M. Fay 2763, K001394828 as G. dahomensis). Copyright of the Board of Trustees of the Royal Botanic Gardens, Kew.

prickle-like simple hairs present on the stem. In contrast, $G$. hirtus has well-expressed stellate pubescence on stem and perianth, and no prickle-like hairs, and (2) the seeds of $G$. ononoides are smooth, whereas those of $G$. hirtus are usually colliculate (however, 
the seeds of the specimens from Senegal, [without date] Perrottet; Botswana, 1982, P.A. Smith; and Somalia, 1893, D. Riva, are smooth). The collections of G. ononoides are very scarce, and the variability of the characters mentioned and the distribution of the species in Asia require further investigations. The morphologically very similar, but phylogenetically distant $G$. radiatus distributed in South and Central America has shorter anthers $(0.35-0.6 \mathrm{~mm}$ long) and stylodia $(0.2-0.6 \mathrm{~mm}$ long) as well as smooth seeds; by contrast, $G$. hirtus has longer anthers $(0.7-0.9 \mathrm{~mm})$ and stylodia $(0.5-1.0 \mathrm{~mm})$ and its seeds are usually colliculate (rarely smooth). Also, the distribution areas of both species do not overlap.

Habitat. River beds, wetlands, damp areas or as a weed, mostly on sandy soils at elevations $0-2400 \mathrm{~m}$ a.s.l. Sometimes, $G$. hirtus is found growing together with $G$. oppositifolius (collections of Cook $405 \& 408$ from Nigeria, K!). Observations in Botswana recorded the following associated plants (A. Heath \& R. Heath 457, K): Cynodon dactylon, Sida cordifolia, Glinus bainesii, Portulaca oleracea, Cyperus polystachyos, $C$. compressus, C. longus, Pseudognaphalium luteo-album. Flowers in early and main rains (obs. in Botswana by A. Heath and R. Heath).

Distribution (Fig. 18). The species was originally known as Mollugo hirta from South Africa (Thunberg 1794) and not reported as a distinct species from any other African territory. Glinus dahomensis was described from Benin (Chevalier 1938), and later reported from Belgian Congo (DR Congo) (Hauman 1951). Hauman (1951) also noted the presence of the species in other territories of tropical Africa ("Du Dahomey au Transvaal"). However, he probably was not sure of that and did not reidentify the specimens from any other countries. We confirm that the range of $G$. hirtus is not restricted to Benin and DR Congo, but the species is distributed in all sub-Saharan Africa and seems to be a common weed in many regions according to the collector's observations. Glinus hirtus has not been previously reported for almost any Sub-Saharan countries (e.g., Adamson 1961; Jeffrey 1961; Berhaut 1967; Gonçalves 1970, 1978; Sita and Moutsambote 1988; Barry and Celles 1991; Mapaura and Timberlake 2004; Phiri 2005; Setshogo 2005; Hassan et al. 2005; Sosef et al. 2006; Germishuizen et al. 2006; Darbyshire et al. 2015). In some West African checklists and manuals it was confused with the American G. radiatus (Berhaut 1967, 1979; Boudet et al. 1986; Akoegninou et al. 2006; Lisowski 2009; Thiombiano et al. 2012; Brundu and Camarda 2013; Schmidt et al. 2017). Only a few specimens from Burkina Faso, DR Congo, and Nigeria were correctly identified as $G$. dahomensis.

Angola (new records): [Moxico prov.] Chizanda, 23 Sep 1899, H. Baum 135 (BM, BR0000018269482, K, M); [Malanje prov.] Malange [Malanje], 21 Sep 1932, R.G.N. Young 846 (BM); Huila [prov.], Lubango, 11 Dec 1955, E.J. Mendes 1083 (BM, LISC032007); Luanda, Namuculungo, 1100 m, 13 Nov 1957, J.B. Teixeira 3185 (LISC032013); Huila prov., Canguelas, Vila Artur de Paiva, 1450 m, 30 Dec 1959, E.J. Mendes 1879 (M); Benguela prov., Ganda, 30 Jun 1960, J.M. Teixeira \& A.M. Andrade 4988 (LISC032014); Cuanza Sul prov., Uaco-Cungo, 2 Nov 1961, J.M. Teixeira \& J.M. Figueira 5956 (LISC032015); [Cunene prov.] Mucope, Tchica [river], 9 Nov 1963, C. Henriques 217 (BM, K, LISC032005); Huila prov., Gambos, 18 Nov 


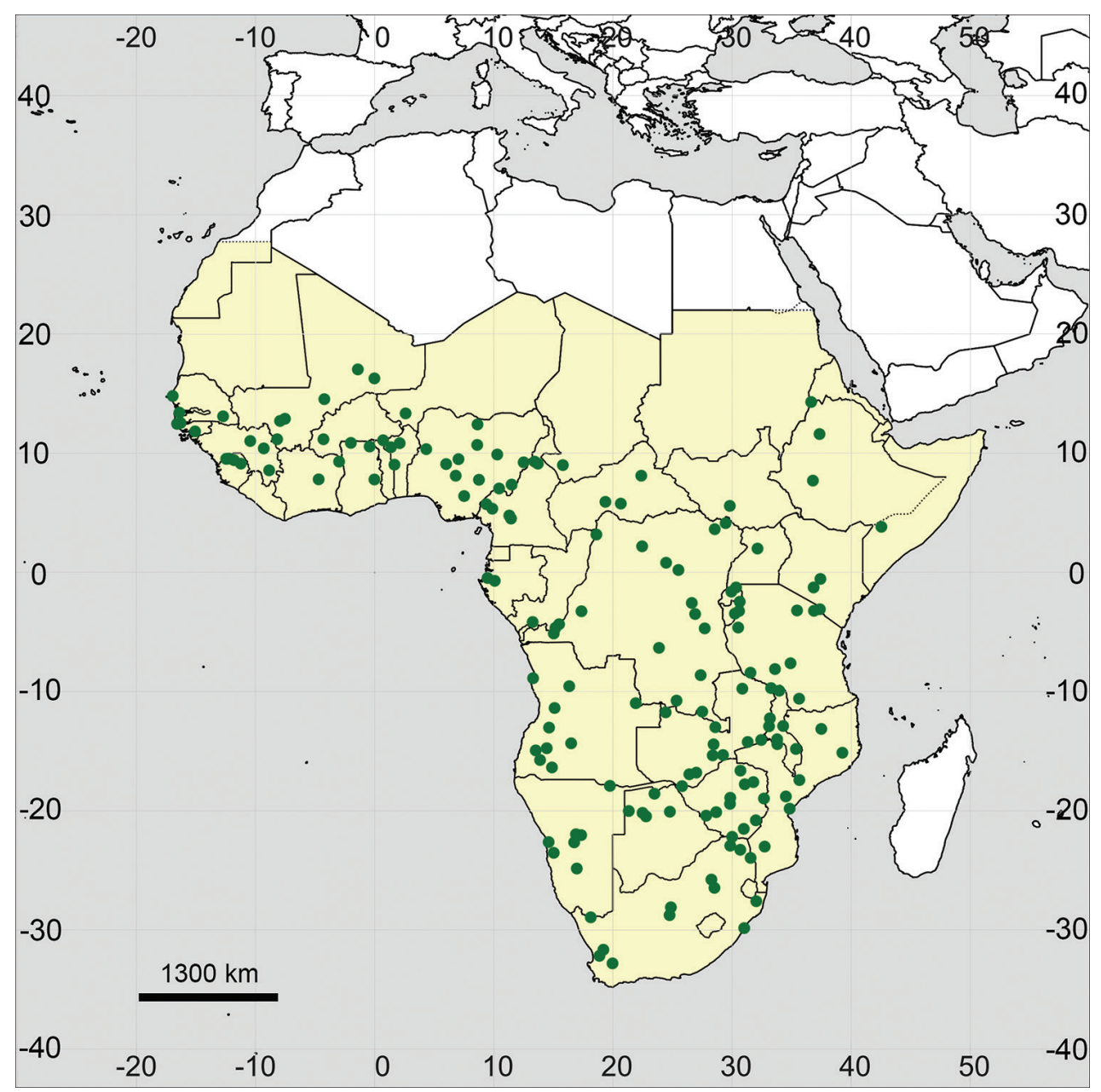

Figure I 8. Distribution map of Glinus hirtus in Sub-Saharan Africa (coloured in yellow).

1970, R.M. Santos \& E. Barroso 2874 (LISC032010); Huila prov., Quipungo, 1200 m, [without date] J.M. Teixeira 12580 (LISC032004);

Benin: see type of G. dahomensis; Atakora [dept.], Toukountouna, 12 Apr 1999, A. Akoegninou et al. 2440 (WAG0235864); Atakora [dept.], Kérou, 16 Apr 1999, A. Akoegninou et al. 2568 (WAG0235868); [Donga dept.] Bassila, 460 m, 30 May 2001, A. Akoegninou 4810 (WAG0235872);

Botswana (new records): Northern distr., Nxauna Pan, 1 Jan 1973, P.A. Smith 318

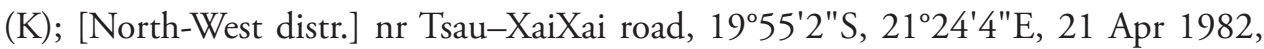
P.A. Smith 3847 (BR0000018269659; PRE0671232, PRE0520975); [Ngamiland distr.] Ngami Lake, 13 Dec 1982, P.A. Smith 3980 (BR0000018269666, E, G, PRE0671267); Ngamiland distr., between Caecae and Gwihaba Hills, 1000 m, 15 Mar 1987, D.G. Long \& D.A.H. Rae 300 (E, K); Zibalianja lagoon, 18³4.728'S, 23³2.145'E, 957 m, 23 Jan 2004, A. Heath \& $R$. Heath 457 (BACH, K); 
Burkina Faso (new records): Kompienga [prov.], $40 \mathrm{~km}$ E of Tindangou, 2 May 2003, L. Sanou \& M. van Slageren 1352 (K); Houet [prov.], 18 km NW of Bobo Dioulasso, 12 May 2003, L. Sanou \& M. van Slageren 1390 (K);

Burundi (new records): [Karuzi prov.] Nyabibuye, $4500 \mathrm{ft}, 15$ Nov 1960, R. Tanner 5602 (K, WAG1 103206); [Ruyigi prov.] Ruyigi, 259'S, 30²8'E, alt. 1450 m, 27 Sep 1978, M. Reekmans 7098 (K);

Cameroon (new records): Southwest region, Mamfe distr., 15 Mar 1953, C.F.A. Onochie et al. 30889 (K); [Centre Province region] 62 km SE of Bafia, 27 Mar 1963, J. Raynal \& A. Raynal 10537 (P0456668); [North region] nr Garoua, Benoue river, 18 Dec 1964, W.J.J.O. de Wilde et al. 4959 (WAG0180494); [Litoral region] plaine des Mbo, $7 \mathrm{~km}$ E of km 25 Melong-Dechang (Dschang) road, 5¹1'24"N, 10¹'12"E, alt. 700 m, 14 Apr 1972, A.J.M. Leeuwenberg \& C.C. Berg 9607 (BR0000018268621, K, P04576510, WAG0185131); North region, Bénoué NP, 7 May 1974, C. Geerling ๙ J. Néné 4705 (BR0000018268591, WAG0330521); [Centre region] river Sanaga,

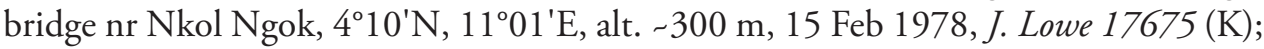

Central African Republic (new records): Kémo [pref.], 17 Feb 1892, Anonymous 691 (P04577135); Ouaka pref., Bambari, 7 May 1927, R.P. Tisserant 2180 (p04577138); [Haute-Kotto pref.] $300 \mathrm{~m} \mathrm{NW}$ of Gounda, 9 ${ }^{\circ} 18^{\prime} \mathrm{N}, 2^{\circ} 12^{\prime} \mathrm{E}$, alt. 450 m, 28 Jul 1982, J.M. Fay 2763 (K001394828);

Chad (new record): [Logone Occidental region] Kim [Krim], 18 May 1969, G. Fotius 1458 (P04576514);

DR Congo (selected): [nr Kinshasa] Stanley Pool [Pool Malebo], 1888, F. Hens 29 (BR0000018268034); [Kongo Central prov.] Kisantu, 1900, J. Gillet 1386 (BR000018268027); Kongo Central prov.] Kisantu, 1903, J. Gillet 3029 (BR000018268010); [Kasai prov.] Zambi vill., 27 Jun 1915, Bequaert 7885 (BR000018268003); [Kwilu prov.] Wombali [Bandundu], Oct 1915, H. Vanderyst 2316 (BR0000018268171); Haut-Katanga prov., Kafubu, 18 Nov 1927, Quarré 804 (BR0000018268386); [Mongala prov.] Bumba, 19 Feb 1931, R. Letouzey \& J.F. Villiers 10386 (K, P04576657, WAG0185129); [Haut-Uele prov.] Garamba NP, 20 Feb 1950, H. de Saeger 147 (BR0000018268232); Orientale prov., Dungu, 2 Apr 1951, H. de Saeger $1084(\mathrm{~K})$; Orientale prov. [Haut-Uele prov.] Dungu, Garamba NP, 28 Mar 1951, H. de Saeger 1119 (K); [Lualaba prov.] Dikuluwe, 21 Aug 1956, J. Brynaert 520 (BR0000018268324, K); [Haut-Katanga prov.] Mitwaba, 2 Nov 1956, J. Brynaert 541 (BR0000018268317, K, LE, L1698856, M, W13591); [Tshopo prov.] Yangambi, 5 Feb 1958, R. Devred 2925 (WAG0185147); [Kasai-Oriental prov.] Katanda Territory, 17 Sep 1959, L. Liben 3701 (BR0000017455121); [Maniema prov.] Kabambare Territory, 10 Aug 1959, 570 m, A. Leonard 5736 (BR0000018268201, WAG0185149); [Maniema prov.] Kamisuku, 700 m, 20 Aug 1959, A. Leonard 6034 (BR0000018268218, P04576678, WAG0185148); Yangambi prov., Bangi, Ile Yangambi, 7 Sep 1959, P. Bamps 700 (BR0000018268188, K); [Haut-Lomami prov.] Bukama, Lualaba river, 570 m, 2 Oct 1970, M. Lukuesa 758 (BR0000018268355, WAG0185146); Kongo-Central prov., Kasangulu, Sabuka, 6 Apr 1972, C. Evrard 6929 (BR0000018269673); Haut-Katanga prov., Kumanua, 1150 m, 18 Dec 1975, 
F. Malaisse 8869 (BR0000018268379); [Eastern prov.] Waine-Rukula, 22 Oct 1978, J. Lejoly 4180 (BR0000017455336); [nr Kinshasa] Inkisi river, 17 Oct 2007, Nsimundele 2060 (BR0000000530230);

EтHiopia (new records): [Amhara region] Begember prov., [years] 1863-1868, Schimper 1340 (K); [Oromia region] Jimma, Apr 1957, Anonymous S2 (K); Godjam prov. [Amhara region], Bahir Dar, 1800 m, Jun 1968, O. Sebald 2166 \& 2255 (M, STU);

Gabon (new records): Moyen-Ogooué prov., Lambaréné, 17 Oct 2012, Boupoya 760 (BRLU0026277); Ogooué-Maritime prov., Wonga-Wongué Reserve, 20 Oct 2014, A. Boupoya \& al. 1087 (BRLU0026275); [Moyen-Ogooué prov.] Onangué Lake, $35 \mathrm{~km}$ SE of Lambaréné, 22 Oct 2014, E. Bidault et al. 1820 (BR0000016174696, BRLU0026276, P00854718);

Gambia (new record): [North Bank Division] Albreda, 1839, Haudelot 100 (G);

Ghana: [Oti Region], on road to Oti from Kete Krachi, 18 May 1952, J.K. Morton 7294 (K); [Upper West region] Tumu, edge of Dam, 25 May 1952, J.K. Morton 7554 (K, WAG0185143); [North East region] Gambaga, 26 Dec 1954, J.K. Morton A1378 (K);

Guinea (new records): [Kankan region] Yri Kiri, 19 May 1955, G. Roberty 18001 (G); [Kankan region] Kankan, Bordo, 26 Apr 1956, J.-G. Adam 12119 (P00695349); [Nzérékoré / Kankan Regions] Simandou Range, Oueléba swamp, alt. 1270 m, 19 Oct 2008, I. Darbyshire 495 (K000580882); [Nzérékoré / Kankan Regions] Simandou Range, Canga East, May 2009, P.K. Haba 579 (K000024353, P00990780, WAG1476650);

Guinea-Bissau (new record): [Bafatá Region], Bambadinca, 11 Jun 1945, Anonymous 2065 (K, WAG0185158);

Ivory Coast (new records): [Vallée du Bandama distr.] Fétékro, 18 Jan 1947, G. Roberty 6915 (G); [Bouna dept.] Bouna, 1 Dec 1986, P. Poilecot 3833 (G40376);

Kenya (new records): [Nairobi] Nairobi Dam, 31 Jan 1961, C. Teesdale 26 (K); Nairobi National Park, 1525 m, 7 Oct 1977, J.B. Gillett \& W.T. Staam 21582 (BM, K); [Eastern prov.] $36 \mathrm{~km}$ from Embu town, 14 Nov 1979, G.W. Gatheri et al. 79/1 (K);

MaLAWI (new records): [Northern region] nr Karonga, 1893-1894, G.F. Scott-Elliot 8403 (BM, K); Zomba, 2500-3500 ft, A. Whyte s.n. (G, P04576503); Nyasaland [without exact location], 1895, J.Buchanan 15 (BM, BR0000018269611, E); [Central region] Dedza Distr., Chongoni Forest reserve, 18 Sep 1967, A.J. Salubeni 832 (K); [Central region] Kasungu distr., Kasungu NP, 12 Dec 1970, A.J. Hall-Martin 1283 (K); [Central region] Kasungu distr., Kasungu NP, 1000 m, 23 Dec 1976, J. Pawek 12032 (K, WAG1103230); [Southern region] Liwonde NP, 9 Oct 1978, A.J. Salubeni \& E. Tawakali 2339 (WAG1103225); Central Region, Mchinji distr., 21 Nov 1983, A.J. Salubeni \& I.H. Patel 3484 (BOL217407); [Central region] Lilongwe Distr., Nature Sanctuary, 8 Nov 1984, I.H. Patel \& al. 1656 (K); Central Region, Nkhotakota distr., 13 May 1986, I.H. Patel \& R.B. Kwatha 3184 (BRLU0026262); Northern region, Chitipa, 958'51"S, 3325'37"E, 1528 m, 18 Dec 2007, H.T. Chapama \& al. 788 (K);

Mali (new records): [Koulikoro region] Koulikoro, 11 May 1912, Vuillet 609 (P04577141); [Inner Niger Delta region] Mopti, 24 Apr 1932, J. Rogeon 76 (P04577146); [Gao region] Bamba, 1927, O. Hagerup 327 (BR0000018268447, K, 
P04576677); [Gao region] Gao, 21 Jun 1936, M. de Wailly 5070 (P04577142); [nr Bamako] Niger river, Sotuba, 4 Jul 1973, D. N'Golo 1291 (WAG0319754); [Sikasso region] Sikasso, Yanfolila, 7 Jul 2009, L. Sanou et al. 624 (K);

Mozambique (new records): [Nampula prov.] Nampula, Mutivasi river, 3 Nov 1942, F.A. Mendonça 1217 (K); [Zambezia prov.] Boroma, 4 miles from Zambesi river, 25 Jul 1950, N.C. Chase 2788 (BM); [Sofala prov.] Gorongosa distr., 300 ft, 26 Sep 1953, N.C. Chase 5087 (BM); Sofala prov., Gorongoza Game Reserve, 25 Aug 1958, N.C. Chase 6980 \& 6981 (BR0000018269185, FT0007098, K); Sofala prov., Gorongosa NP, 3 Nov 1963, A.R. Torre \& J. Paiva 9006 (BR0000018269161, M); [Sofala prov.] Beira, Jul 1970, K.L. Tinley 1936 (BR0000018269642); Sofala prov., Gorongosa NP, Jul 1970, K.L. Tinley 1938 (K); Gaza prov., Caniçado, 17 Nov 1970, M.F. Correia 2018 (WAG1103222); Niassa prov., Lugenda river, Marrupa to Mecula, 11 Aug 1981, P.C.M. Jansen et al. 225 (K, WAG0312529); Sofala prov., Gorongosa NP, 1855'4.8"S, 34³0'38.04"E, 9 Nov 2007, P. Ballings \& B. Wursten 944 \& 958 (BR581135 \& BR0000018269635);

Namibia (new records): [Otjozondjupa Region] Okahandja, Nov 1906, K. Dinter 301 (BM, BR0000018269222, E, G, K, P04577101, U139844, WU, Z-000092198); [Khomas region] Windhoek, 21 Dec 1929, C.E. Moss 18055 (BM); [Khomas region] Khomas Highland, Friedenau Farm, 2000 m, 6 Apr 1939, G. Gassner 124 (M); [Erongo region] Swakopmund distr., Goabeb Research Station, 9 Oct 1963, C. Koch s.n. (K, PRE0403669); [Hardap region] 30 miles E of Maltahöhe, $4400 \mathrm{ft}, 15 \mathrm{Feb}$ 1950, E.C.Macdonald 369 (BM); [Kavango-East region] Rundu [between Kapuko \& Sambiu], 22 Dec 1955, B. de Winter 4035 (K, M, PRE0403672); [Khomas region] Windhoek, 1575 m, 29 Apr 1961, R. Seydel 2819 (B101143626, G, L1693130); [Erongo region] Swakopmund, mouth of Swakop river, 11 Feb 1962, R. Seydel 3041 (B101143623, M); [Khomas region] Windhoek, Swakop river, 2000 m, 20 Feb 1965, R. Seydel 4194 (B101143629, B101143630, K);

Niger (new record): [Tillabéri region] Kouré, 8 Mar 1897, G. Roberty 2556 (P04577117);

Nigeria (new records): [Benue State] Abinsi, 29 May 1912, J.M. Dalziel 715 (K); [Jigawa State] Takara, 3200 ft, 4 May 1921, H.V. Lely 101 (K); Adamawa State, Jimeta (Yola), 29 Dec 1957, F.N. Hepper 1621 (K); [Niger State] Shagunu, $10 \mathrm{~km}$ N of Bussa, 25 Jul 1965, C.D.K. Cook 405 (K); Niger State, Bida distr., 1 Mar 1968, B. O. Daramola \& A. Binuyo 61930 (K); [Taraba State] Sardauna area, Bissaula, 18 Dec 1968, B.O. Daramola 62328 (K); [Taraba State] Gashaka distr., Gashaka river, $1100 \mathrm{ft}, 25 \mathrm{Mar}$ 1970, Z.O. Gbile \& B.O. Daramola 23888 (WAG0185150); Bauchi State, Yankari Game Reserve, 24 Mar 1971, C. Geerling 3486 (B100480213, BR0000017456135, WAG0083282); Gombe State, Dadin Kowa, Gongola river, 2 May 1972, Gbile et al. 65453 (K); Adamawa State, Yola distr., 6 May 1972, Gbile et al. 1303 (K); Enugu State, Amechi vill., 21 Feb 1973, Latilo \& Oguntayo 67620 (K, WAG0185136); [Kogi State] Koton Karfe, Niger river, 22 Mar 1973, Eimunjeze et al. 70400 (K); Niger State, Kafin Koro, 23 May 1973, Eimunjeze et al. 66496 (K); 
Republic of the Congo (new record): [Bouenza dept.] Jacob [Nkayi], 27 Sep 1969, Y. Attims 255 (WAG00034942);

Rwanda (new records): Mutara area, $1400 \mathrm{~m}$ a.s.l., 3 Oct 1956, G. Troupin 2810 (BR0000017455824, K); [Eastern prov.] Nyagatare, 1450 m, 27 Jan 1958, G. Michel 5077 (BR0000017455817);

Senegal (new records): [without exact location and date] Perrottet 373 (G, P04577123); Wab, 20 Dec 1824, Perrottet 51 (P04577122); [Waalo Region] N'ghiau, [without date] Lepiers.n. (G); Oussodou, 2 Jan 1954, R.P. Berhaut 4330 (P04577147); [Ziguinchor Region] Bignona, 22 May 1957, J.-G. Adam 13656 (P04577113); Niokolo Koba NP, Feb 1960, J.-G. Adam 17485 (P04577114); Basse Casamance [Ziguinchor], 11 Jul 1963, R.P. Berhaut 6084 (BR7000919, P04577119); Basse Casamance [Ziguinchor], 29 Jul 1977, C. Vanden Berghen 1915 (BR0000018268461, WAG0106332);

Sierra Leone (new records): [Northern prov.] Samaia, 10 May 1914, N. W. Thomas 245 (K); [Northern prov.] Mange, 21 Feb 1949, F.C. Deighton 4978 (K); [Northern prov.] Yifin, 23 Mar 1964, Norton \& Gladhill 994 (K, WAG0185139); [Northern prov.] Koinadugu distr., SE of Fadugu, 21 May 2014, X.M. van der Burgt 1854 (K);

Somalia (new record): [Gedo prov.] nr Ganane, Mar 1893, D. Riva 736 (G, RO);

South Africa: [Gauteng prov.] Pretoria, Apies river, [without date] ex herb. J. Burtt Davy s.n. (K); [Gauteng prov.] Pretoria distr., Apies river, [without date] Zeyher 612 (K); [Western Cape] Clanwillam, Feb [no year] Zeyher \& Ecklon 1818 (P04577109); [Western Cape] Clanvillam, secus fluvium Olifantsrivier ad villam Brackfontein, Jun 1847 Zeyher 612 (P04577110, P04577124); Cape of Good Hope, 1847, C.-L. Zeyher 612 (FR-0132679, G, LE, P04577110); Northern Cape, Henkries, 30 Nov 1897, B. Schlechter s.n. (BR0000018269291, G, LE, L1693128, P04576623, WAG1103197, Z-000092196); [Limpopo prov.] Musina, 2000 ft, [without date] F.A. Rogers 22240 (G); [KwaZulu-Natal prov.] Durban, Sep 1904, M. Wood s.n. (L1693126); [Limpopo province] Messina [Musina], Nov 1917, Moss \& Rogers 57 (BM, K); [Mpumalanga prov.] Klipfontein, Nov 1937, J.P.H. Acocks 5145 (K); [Transvaal prov.] Zoutpansberg, Kruger Nat. Park, 800 ft, 2 Nov 1948, O’Dyer 4630 (K); [Northern Cape] Lokenburg, 2100 ft, 16 Mar 1957, J.P.H.Acocks 19196 (K, M, PRE0403696, PRE04036962); [Northern Cape prov.] Kimberley, Rooipoort, 3450 ft, 1 Dec 1958, O.A. Leistner 1210 (K); Cape Prov., [Northern Cape prov.] Warrenton, [without date] J.P.H.Acocks 15916 (K); [KwaZulu-Natal prov.] Ubombo Distr., Mkuzi Gane reserve, 9 Dec 1959, C.J.Ward 3353 (K, M); Transvaal prov., Kruger NP, 350 m a.s.l., 27 Jan 1982, J. Lambinon \& M. Reekmans 82 (BR0000018269246, MSB-129442, PRE0626149); [Limpopo prov.] Giyani distr., 18 Oct 1988, S. Venter 13049 (PRE0810982);

South Sudan (new record): [Equatoria Region] Zande, 6 Mar 1940, J.W.G. Wyld $781(\mathrm{BM})$;

TANZANIA (new records): [Ruvuma region] $7 \mathrm{~km} \mathrm{~W}$ of Songea, $990 \mathrm{~m}, 18$ Jan 1956, E. Milne-Redhead \& P. Taylor 8355 (BR0000018269017, K); [Rukwa region] Sundu Lake, 1500 m, 13 Dec 1958, H.M. Richards 10316 (K); Kigoma region, Mugombasi, 1 Sep 1959, R.M. Harley 9495 (K); [Kagera region] Ngara, 4500 ft, 
6 Sep 1960, R. Tanner 5126 (BR0000017454308, K, WAG1103204); [Singida region] Ruaha NP, Great Ruaha river, 840 m, 19 Jan 1966, M. Richards 21007 (K); Arusha region, Ngurdoto Crater NP, 22 Mar 1966, P.J. Greenway \& Kanuri 12474 (BR0000017454285, K); Arusha region, Arusha NP, 1524 m, Nov 1969, M. Richards 24683 (K, M); [Singida region] Ruaha NP, 820 m, 12 Oct 1970, A. Bjørnstad 601 (K); [Arusha region] Ngorongoro Conservation area, 2200 m, 30 Dec 1988, T. Pocs \&.S. Chuwa 88308 (K); Mbeya region, 19 Dec 1989, J. Lovett et al. 3775 (L0717072, P04576671); [Kilimanjaro region] Kilimanjaro, 1220 m, 2 May 1994, J.M. Grimshaw s.n. (K);

Uganda (new record): [Western region] Kiryadongo, 3200 ft, Mar 1943, Anonymous $1338(\mathrm{~K})$;

Zambia (new records): [North-Western prov.] Mwinilunga distr., 6 Nov 1937, E. Milne-Redhead 3115 (BR0000017454414, K); [Southern prov.] Mapanza, 20 Sep 1953, E.A. Robinson 324 (BR0000018269109, K); [Copperbelt prov.] Ndola, 23 Jun 1955, D.B. Fanshawe 2343 (B101143625, BR0000018269604, K); [Lusaka prov.] S of Lusaka, Kafue river, $3000 \mathrm{ft}, 11$ Dec 1955, E.B. Best 121 (K); [Eastern prov.] Lundazi, Tigone Dam, 1200 m, 19 Nov 1958, N.K.B. Robson 655 (BM, K); [Southern province] Choma, 25 Oct 1958, E.A. Robinson 2900 (M); [Eastern prov.] stream beside Chadiza turn-off, Nsadzu to Fort Jameson [Chipata], 900 m, 25 Nov 1958, N.K.B. Robson 703 (BM, BR0000017454438, K); [Northern prov.] Kali Dambo, [without date], H.M. Richards 4091 (K); [Central prov.] Broken Hill [Kabwe], 14 Oct 1959, J.M. Mutimushi 74 (K); [Eastern prov.] Chimutengo/Petauke, 3 Oct 1966, J.M. Mutimushi 1542 (K); Lusaka prov., Chitendabunga, 1200 m, 13 Nov 1993, M.G. Bingham 9795 (WAG1103214);

Zimbabwe (new records): Bulawayo, May 1898, R.F. Rand 331 (BM); Salisbury [Harare], Sep 1919, Eyles 1806 (K); [Matabeleland North prov.] Victoria Falls, Nov 1933, A. Meebold 11992 (M); [Matabeleland South prov.] Beitbridge, Limpopo river, 21 Dec 1935, Smuts \& Gillett 3108 (PRE0800058); [North-Western prov.] Salisbury [Harare], Makabusi river, $4500 \mathrm{ft}, 24$ Oct 1945, H. Wild 269A (K); [Matabeleland South prov.] Bulalimamangwe distr., Tegwani, 8 Jan 1946, F.W.J. McKosh 14297 (K); [Manikaland prov.] nr Mutare, 3500 ft, 29 Dec 1946, B.S. Fisher 16533 (K); Nuanetsi, 1850 ft, Nov 1955, R. Davies 1610 (K); Bulawayo, 4800 ft, Dec 1956, O.B. Miller 4000 (BR0000018269628, K); [Mashonaland West prov.] Urungwe distr., Zwipani Vlei, 30 Nov 1957, R. Goodier 425 (K); [Matabeleland South prov.] Nuanetsi, 2050 ft, 6 May 1958, R.B. Drummond 5599 (K); [Matabeleland South prov.] Gwanda Distr., nr Chikwarakwara, 12 May 1958, R.B. Drummond 5789 (K); [Mashonaland Central prov.] Sipolilo, Angwa river, 3 Jun 1965, M.G. Bingham 1548 (BR0000018269550); [Midlands prov.] Owelo [Gweru], 4200 ft, 30 Dec 1965, B.K. Simon 587 (K); [Midlands prov.] Kwekwe distr., Sable Park, 26 Feb 1976, J.M. Stephens 340 (M, WAG1103229);

General distribution. Africa (Sub-Saharan Africa; North Africa: Egypt [WU!]; Madagascar: G! K!). 
Glinus lotoides L., Sp. Pl. 1: 463 (1753).

$\equiv$ Mollugo glinus A.Rich., Tent. Fl. Abyss. 1: 48 (1847), nom. illeg. superfl. Lectotype (Adamson: 1961: 127): [icon] Alsine lotoides sicula in Boccone (1674: 21, tab. 11, figure B). Superseded neotype (Jeffrey 1961: 15): [Italy] Sicily, Boccone (OXF, n.v.). Note. The protologue of Glinus lotoides L. is based on two main elements, an illustrated treatment of Alsine lotoides sicula from Sicily (Boccone 1674: 21, tab. 11, figure B) and another illustrated treatment of Portulaca baetica, luteo flore, spuria aquatica from Spain (Barrelier 1714a: 47, 1714b: figure 336). Linnaeus had not seen any specimen of the species prior to the publication of the protologue (Adamson 1961), in particular the collection of P. Boccone at OXF (Jarvis 2007). The herbarium collections of J. Barrelier are no longer extant (cf. Morton 1970) and had seemingly never been consulted by any botanist because all Barrelier's legacy but drawings was destroyed by fire after his death (Barrelier 1714a). There were two attempts to lectotypify the name Glinus lotoides. Jeffrey (1961) designated a specimen collected by Boccone and kept at OXF; although this specimen is associated with the illustration in Boccone (1674), it was not examined by Linnaeus and therefore is not part of the original material. Jeffrey's lectotypification is in effect neotypification. Adamson (1961) designated the illustration in Boccone (1674) as lectotype. This lectotypification is correct and supersedes the neotype designated by Jeffrey.

= Holosteum hirsutum L., Sp. Pl. 1: 88 (1753). Holotype: India. Ex Malabariae [Malabar Coast], Hb. Van Royen 899 (L, n.v., after van Steenis 1966).

= Glinus dictamnoides Burm.f., Fl. Ind.: 113 (1768). Lectotype (designated here): [icon] Plate 356, figure 6 in Plukenet (1705). Note. The name G. dictamnoides was erroneously attributed by Fenzl to Linnaeus (1771); however, the latter clearly refers to Burman's "Flora Indica" where G. dictamnoides was described (Burman 1768). Burman (1768) cited no specimens in the protologue. Both Burman (1768) and Linnaeus (1771) cited Plukenet (1705) who depicted this plant in the Plate 356, figure 6 . This image shows a hairy shoot with the rounded leaves in whorls and almost sessile verticillate flowers. The obovate vs. orbicular leaf shape was the main character known to Burman to distinguish G. lotoides and G. dictamnoides in situ (Burman 1768; see also a drawing of $G$. lotoides in the table 36, figure 1). The orbicular and greyish-green leaves of $G$. dictamnoides were similar to those of Dictamnus creticus Garsault (三 Origanum dictamnus L.), and such plants were found in Madras [now Chennai], India: "dictamni cretici facie, maderaspatana". Based on the protologue of $G$. dictamnoides, Merrill (1921) synonymized this species name with $G$. lotoides. In agreement with Merrill's opinion, we designate the cited illustration as lectotype and retain Burman's name in the synonymy of $G$. lotoides. The specimens seen from India usually have rounder leaves with \pm scattered pubescence and shorter perianth (usually $5.5 \mathrm{~mm}$ long in fruiting) compared to the European populations, which have obovate and usually hirsute leaves and longer perianth reaching $6.5-8.5 \mathrm{~mm}$ 
in length. These characters were presumably the main argument to consider the Indian plants as $G$. lotoides subsp. hirtus (Almeida 1998) based on the name Mollugo hirta described from South Africa but erroneously applied to Indian plants (Clarke 1879). Mollugo hirta represents the plants with different characters (see also notes under $G$. hirtus). The African plants corresponding with $G$. dictamnoides are present in eastern and southern parts of the continent. It should be noted that the density of pubescence is very diverse in African plants, and those growing in a humid climate (e.g., Nigeria, Cameroon) usually have green leaves with scattered hairs. The intermediate forms in leaf shape and pubescence degree were frequently seen in the herbarium collections. In light of our molecular studies showing a mixed position of $G$. lotoides and $G$. dictamnoides, and scarce morphological differences between them, we prefer to synonymize $G$. dictamnoides with $G$. lotoides.

= Tryphera prostrata Blume, Bijdr. Fl. Ned. Ind. 11: 549 (1826). Note. Described from two localities on the Island of Java, Indonesia: Pamanukan and Cheribon [Cirebon]. The authentic specimens are not traced, but the description of the genus and species (Blume 1826) indicates the identity of $T$. prostrata to G. lotoides.

= Pharnaceum pentagynum Roxb., Fl. Indica 2: 103 (1832). Lectotype (designated here): [without location, year and collector] "Hb. Roxb." (K000641797!). Note. Another authentic specimen was found at BR: "Herb. Roxburghii" (BR0000005227204).

= Glinus lotoides var. virens Fenzl, Ann. Wiener Mus. Naturgesch. 1: 358 (1836).

三 Mollugo glinus var. virens (Fenzl) Oliv., Fl. Trop. Afr. 2: 590 (1871). Lectotype (Adamson 1961): South Africa. At the junction of Fish and Orange rivers, left side of the Orange River (ca. -28.1, 17.175): ["Garip, bei Verleptpram, am Ufer des Flusses und in der steinigen Niederung, unter 500 Fuss”, 17 Sep 1830,] J.F. Drège (K000232021; isolectotypes HAL0117929, HBG516708, K000232020, S055102, S05-5103). Note. In the type citation, the locality information is added from Drège (1843: 92) and the collection date is complemented from Gunn and Codd (1981). When establishing G. lotoides var. virens, Fenzl (1836) cited several validly published plant names as synonyms ( $G$. dictamnoides, Pharnaceum pentagonum, Physa madagascariensis), and also illustrations and specimens. Since this new name was at the rank of variety and the synonyms were at the rank of species, and Fenzl provided his own description and used his own original material, his variety does not need to be treated as based on any of the synonyms included. Indeed, Adamson (1961) designated a separate type for this varietal name, a specimen collected by Drège in South Africa and cited by Fenzl (1836) in the protologue. This lectotypification is technically correct and should therefore stand. Fenzl (1836) established his variety for the plants that are less villose (or glabrescent at maturity) than the type variety of $G$. lotoides, with the perianth $5 \mathrm{~mm}$ long, and without petaloids. The distribution area of this new variety was circumscribed as East India, Timor, Arabia, Madagascar, and South Africa (Fenzl 1836). This variety was accepted by the later authors, and its range was widened to include many regions of tropical Africa (Oliver 1871 sub Mollugo glinus var. virens; Adamson 1961; Gonçalves 1970, 1978; Figueiredo and Smith 2008; Klaassen and Kwembeya 2013). 
However, many sheets of similar looking species (G. hirtus and G. zambesiacus) were previously identified as $G$. lotoides var. virens, and this name was therefore used erroneously in many treatments.

= Glinus micranthus Boiss., Diagn. Pl. Orient., ser. 1, 10: 11 (1849). Holotype: [Lebanon] Rascheya [Rachaiya], in ruderatis, May-July 1846, E. Boissier s.n. (G00506579!) located at G-BOIS!

Description. (Fig. 19). Annual, stellate pubescent. Stems prostrate or ascending, sometimes reaching $2 \mathrm{~m}$ in length, but usually shorter (up to $70 \mathrm{~cm}$ ), prickles absent. Leaves grey or light green, usually moderately pubescent, sometimes bicolored (light green adaxially and grayish-green abaxially), entire, crisp or denticulate, obovate, broadly obovate or almost roundish; petioles $2-10(15) \mathrm{mm}$, blades (10)15-60 × 4-20(25) mm, mucronulate. Flowers in clusters of 4-12, distant; sessile or with pedicels up to $15 \mathrm{~mm}$ (in fruiting the pedicels, if present, may be up to $20 \mathrm{~mm}$ long); white or yellowish, sometimes rusty inside and white abaxially, mid-vein green; flower buds and anthocarp ovoid. Perianth segments (tepals) oblong or ovate, entire or sometimes denticulate, in flowering 5.0-6.5 mm long, in fruiting 7.0-8.5 $\mathrm{mm}$ long, with a mucro $0.5-1.0 \mathrm{~mm}$ long; white petals (1-3) sometimes present (usually much shorter than tepals). Stamens (5)10-16[ $\infty$, obdiplostemonous or alternisepalous, outer stamen series (petaloids) sterile, terminating with 1-3 teeth; anthers 0.7-1.0 mm long. Stigmas (3)5, $0.9-1.5 \mathrm{~mm}$ long (sometimes a style is present up to $1.0 \mathrm{~mm}$ long). Seeds $0.45-0.6 \times$ $0.40-0.55 \mathrm{~mm}$, dark red or almost black, colliculate and without longitudinal striae; aril hood easily visible, $0.20-0.30 \mathrm{~mm}$ long.

Note. The five-staminate and three-carpellate individuals of $G$. lotoides are considered here as abnormal forms that seem to be very rare. We assume that such specimens investigated earlier in relation to the floral formulae by Müller (1908) rather belong to G. hirtus.

The plants with green or glabrescent leaves are more common in the wet climate (e.g., West Africa), and the densely pubescent populations are most frequent in drier conditions (Fig. 20).

Habitat. Sandy sites in river valleys, limestone, clayey and rocky places, seasonally inundated areas; at altitudes of up to $2000 \mathrm{~m}$. This species prefers semiarid regions and only limited number of specimens from West Equatorial Africa are present in the collections.

Distribution (Fig. 21). Angola: [Luanda prov.] Barra do Bengo, Jan 1853, F. Welwitsch 2415 (BM); Luanda distr., between 8 and 9 ${ }^{\circ}$ S, Alto das Cruzes, Sep 1857, F. Welwitsch 2412 (BM, K, LE, M, P04576620); [Namibe prov.] Mossamedes, Cabo Negro, Sep 1859, F. Welwitsch 2416 (BM, K); [Namibe prov.] Mossamedes, Cavalheiros, Jul 1860, F. Welwitsch 2413 (BM); [Namibe prov.] Bero and Giraul rivers, Jun 1900, J. Gossweiler 72 (COI00070553); Luanda, 1903, J. Gossweiler 223 (BM, LISC031995, P04576560); [Cunene prov.] nr Cahama, 18 May 1909, H.H.W.Pearson 2545 \& 2548 (BM, BOL217405, K); [Namibe prov.] Mossamedes, Rio Croca, 3 Jun 1937, L.W. Carrisso \& F. Sousa 242 (BM, LISC031994); [Namibe prov.] Porto Alexandre, 15 Sep 1955, E.J. Mendes 79 (BM, LISC031997); [Namibe prov.] Mossamedes, Camucuio, 14 Oct 1955, E.J. Mendes 410 (LISC031998, M); Cuanza Sul prov., Foz do Rio Cuvo, 4 Mar 1967, J.B. Teixeira et al. 

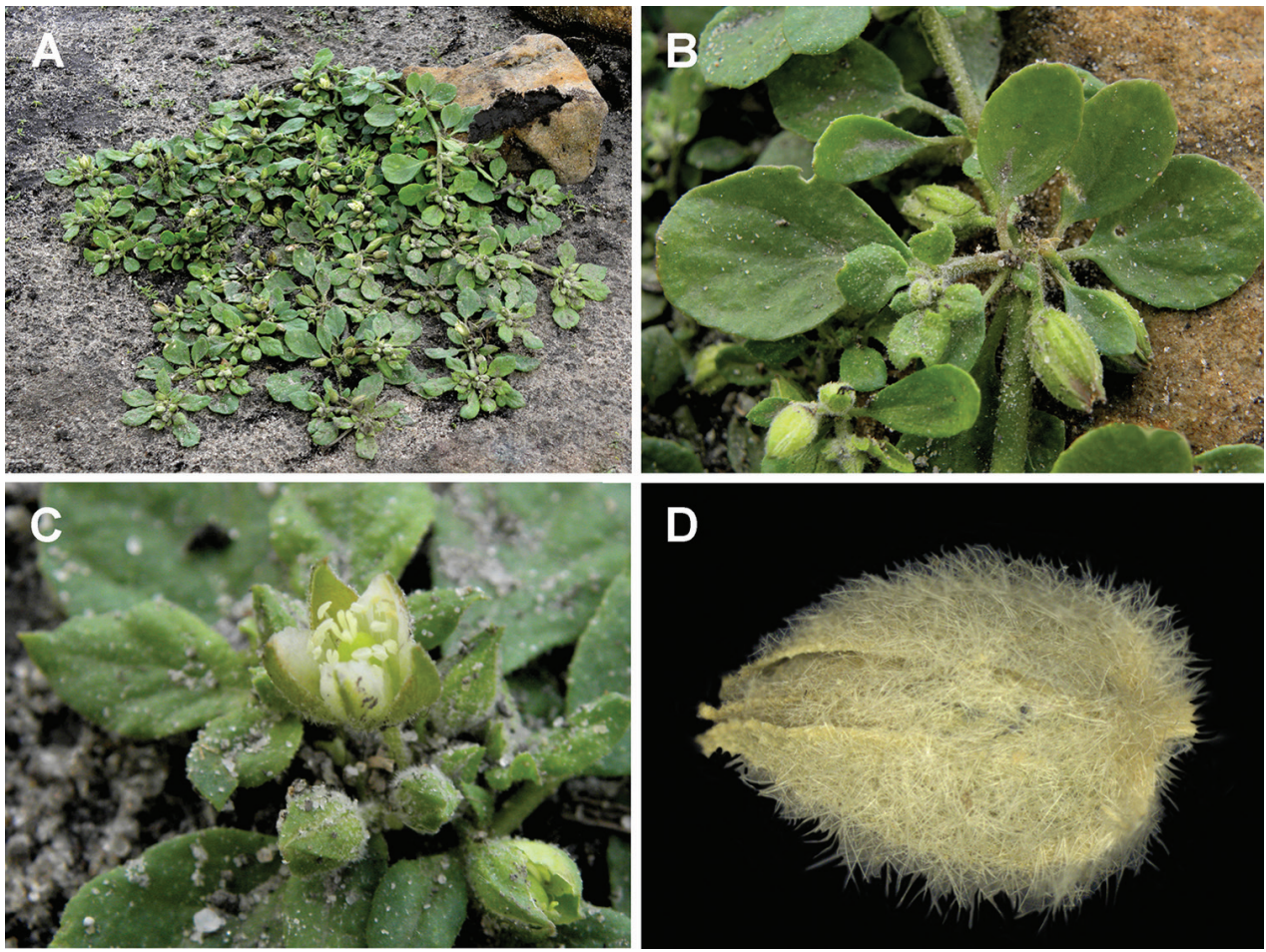

Figure 19. Glinus lotoides $\mathbf{A}$ an overview of the plant $\mathbf{B}$ close-up of the leaves and buds $\mathbf{C}$ close-up of the flower D closed anthocarp. Photographer - Ridha El Mokni (Sidi Mechrig - Sejnane, Bizerta Governorate, Tunisia, 23 Oct 2015).

11054 (LISC032003, WAG0104171); [Huila prov.] Chiange, 4 Dec 1970, J.A. de Sousa 86 (K, LISC032011);

Benin: Zou dept. 8 Mar 1970, L. Aké Assi 11109 (G); [Alibori dept.] Malanville, 13 Nov 1998, V. Adjakidjè 2593 (WAG0235875); [Alibori dept.] Malanville, $11^{\circ} 52^{\prime} \mathrm{N}$, $3^{\circ} 23^{\prime} \mathrm{E}$, alt. 270 m, 26 Apr 1999, P. Houngnon et al. 6507 (BR0000018268560, K, WAG0235862); Atakora dept., Tanguiéta, 20 Jul 2000, B. Sinsin 3667(WAG0235863);

Botswana: Ngamiland distr., Kwebe hills, 28 Dec 1897, E. Lugard 73 (K); [Bakgatla tribal region] Mochudi, $24^{\circ} 10^{\prime} \mathrm{S}, 26^{\circ} 05^{\prime} \mathrm{E}, 1914$, C.C. Harbor 6584 (BM); [Bakgatla tribal region] Mochudi, Jan 1914, F.A. Rogers 6584 (PRE0403681); [Ngamiland distr.] Maun, Dec 1967, F.L. Lambrecht 449A (K); nr Maphaneng, 1956.75'S, $23^{\circ} 26.2^{\prime} \mathrm{E}, 4$ Dec 1977, P.A. Smith 2115 (K);

Burkina-Faso: [Oudalan prov.] Markoye, 15 Aug 1975, Anonymous 45121 (P04576576); [Sanmatenga prov.] NE of Pissila, 18 Jun 1987, J. Lejoly 87/071 (BRLU0026261); [Oudalan prov.] Oursi, 10 Oct 1988, S. Guinko s.n. (WAG0042080); Oudalan prov., Tin Akoff, 7 Oct 1998, S. Kahlheber 1001 (FR-0108631); Oudalan prov., Yomboli, 24 Jul 1999, J. Müller 82 (FR-0014419); Sourou prov., $50 \mathrm{~km} \mathrm{~W}$ of Tougan on road to Kassoun, $13^{\circ} 10^{\prime} \mathrm{N}, 3^{\circ} 25^{\prime} \mathrm{W}$, alt. 276 m, 16 Apr 2002, L. Sanou 100 (K); 


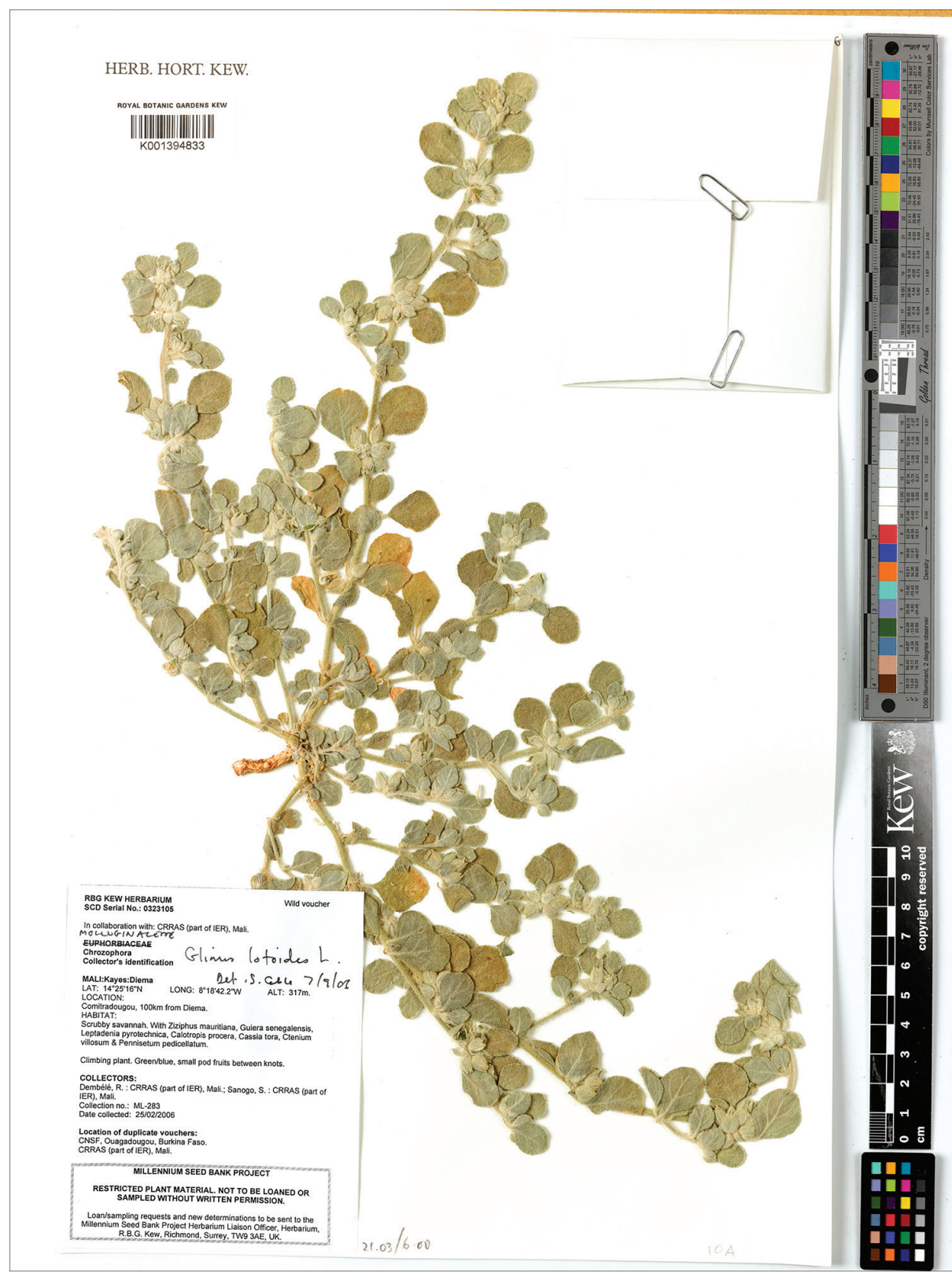

Figure 20. A herbarium specimen of Glinus lotoides (Kayes region, Comitradougou, $100 \mathrm{~km}$ from Diéma, $14^{\circ} 25^{\prime} \mathrm{N}, 8^{\circ} 18^{\prime} \mathrm{W}$, alt. $317 \mathrm{~m}, 25$ Feb 2006, R. Dembele et al. ML-283, K001394833). Copyright of the Board of Trustees of the Royal Botanic Gardens, Kew.

BuRundi: Bujumbura, plaine de la Ruzizi km 25, alt. 850 m, 28 Sep 1966, J. Lewalle 1046 (K); Bujumbura, 800 m, 28 Sep 1971, J. Lewalle 6145 (BR0000018269406, G, WAG0104170); Bubanza prov., Gihungwe, 800 m, 23 Nov 1974, M. Reekmans 3952 


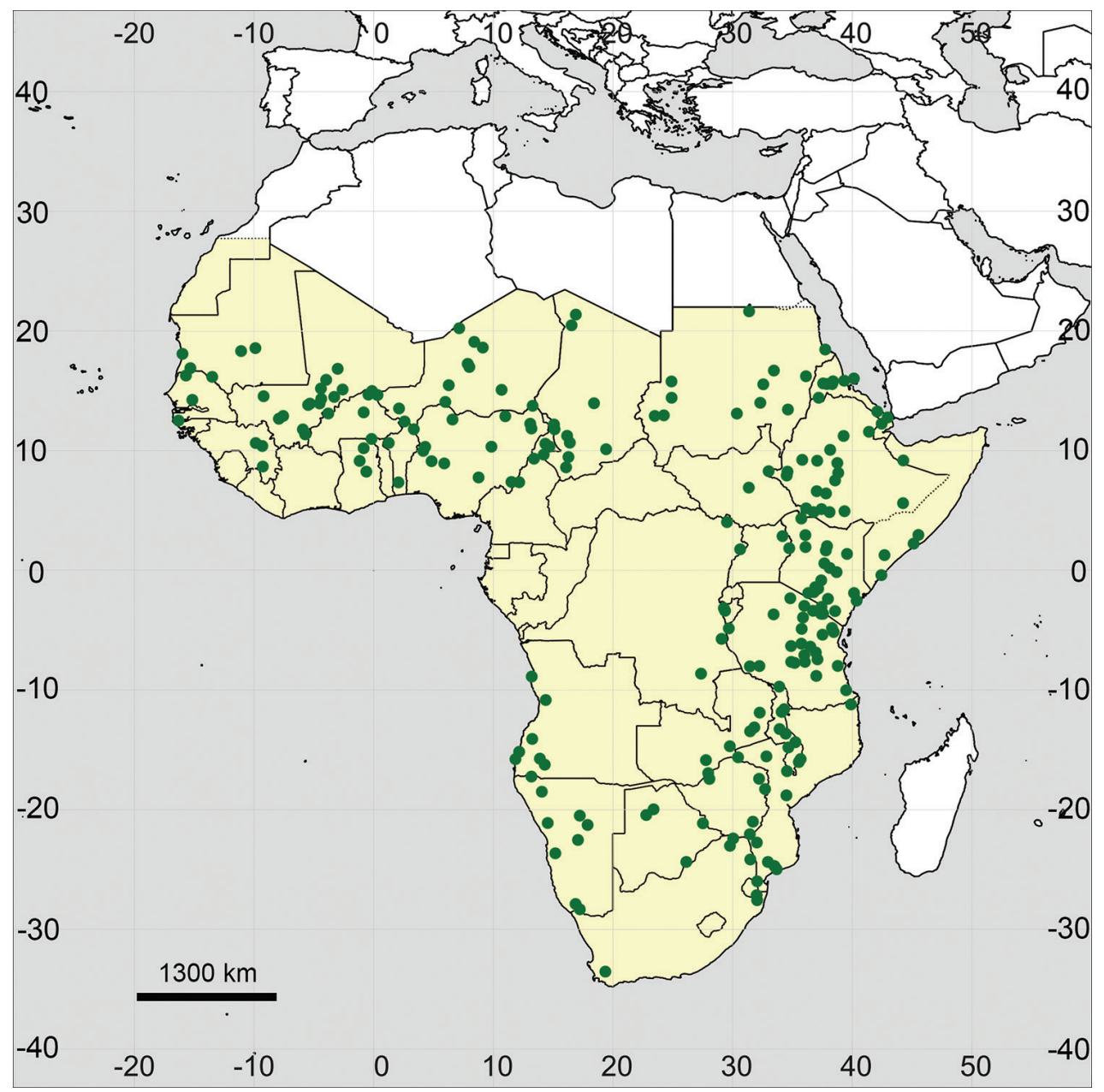

Figure 2 I. Distribution map of Glinus lotoides in Sub-Saharan Africa (colored in yellow).

(BR0000018269437, K, MSB-129441); Bubanza prov., Gihungwe, alt. 850 m, 2 Feb 1975, M. Reekmans 4296 (K); Bubanza prov., 3 Dec 1977, M. Reekmans 6677 (K, L0717151, LE, P04576512, PE01696732, WAG0104169);

CAMERoon: [Adamawa region] Mayo Lidi, 5 Mar 1933, H. Lhote 82 (P04576622); [Far North region] Dargala, $30 \mathrm{~km}$ ESE of Maroua, 21 Aug 1964, R. Letouzey 6314 (K, P04576655, WAG0104162); [Far North region] nr Maroua, 400 m, 13 Sep 1964, W.J.J.O. de Wilde et al. 3240 (BR0000018268638, P04576568, WAG0185134); North region, Garoua, 7 Jun 1975, P. Wit 3056 (BR0000018268607, PE01942337, WAG0317794); [Far North region] Logone-Birni, 9 Jan 1975, D. Dulieu 55720 (P04576563);

ChaD: Chari-Baguirmi region, Dar Goulla, 28 Mar 1903, A. Chevalier 7872 (K, P04576585); Tibesti region, Oct 1931, A. Chevalier s.n. (P04576654); [Moyen-Chari region] Iro Lake, 12 Jul 1939, S. de Ganay 127 (P04576532); [Batha region] Mare de 
Dalato, 31 Aug 1960, H. Gillet 2375 (P04576666); S of Fort Lamy [N'Djamena], 3 Jan 1963, W.J.J.O. de Wilde et al. 5188 (BR0000018268676, P04576511, WAG1103207); [Logone Occidental region] nr Moundou, 26 Mar 1963, B. Descoings 10624 (P04576565); Mayo-Kebbi Ouest region, ne Leré, 30 Mar 1963, B. Descoings 10727 (P04576567); [Tibesti Ouest Region] nr Zouar, 28 Jan 1965, H. Scholz 58 (B101143617); [Far North region] Delta of Chari, Djimtilo, 29 Jan 1968, J. Léonard 4419 \& 4420 (BR0000018268614; BR0000018269505, P04576643); [Tandjile region] Satégui, 9 Dec 1968, G. Fotius 1281 (P04576513); N’Djamena, 28 Jul 1984, S. Lisowski B-39 (WAG1103213); N'Djamena, 5 Feb 1985, S. Lisowski 1808 (BR0000018268706);

Dјıвоuтr: [Tadjourah Region] Andabba [Lake], 6 Jan 1957, E. Chedeville 1756 (FT0007026, P04576543);

DR Congo: [Katanga prov.] Kampunda, $3200 \mathrm{ft}, 16$ Oct 1950, A.A. Bullock 3430 (B101143607, K); [Haut-Uele prov.] Garamba, 700-800 m, 19 Nov 1952, G. Troupin $74(\mathrm{~K})$; [North Kivu prov.] Albert Lake, 5 Mar 1954, D. van der Ben 1185 (BR0000018269314, K); Katanga, Mitwaba, 21 Aug 1956, J. Brynaert 520 (K)

ERITREa: [Anseba prov.] Keren, May 1870, O. Beccari 45 (FI059438, FT0007013); Dahalak [island] Mar 1892, A. Terracciano 819 (FT0007080); [Southern Red Sea Region] Adarte, 26 Jan 1893, A. Terracciano \& A. Pappi 2741 (FT0007022); [Gash-Barka region] Barea Agordat, 27 Jan 1893, A. Terracciano 2852 (RO); [Anseba prov.] Bogos, 3 Feb 1893, A. Terracciano \& A. Pappi 2598 (FT0007023); [Gash Barka Region] Mansura, 9 Sep 1905, A. Pappi 6400 (FT0007016); [Gash-Barka region] Damtai, 30 Jan 1909, A. Pappi 7840 (FT0007003); [Gash Barka Region] Mansura, 10 Feb 1909, A. Pappi s.n. (LE); [Gash-Barka region] Barea Agordat, 23 Feb 1909, A. Fiori 978 (FT0007029); [Gash-Barka region] Scetel, Dec 1905, A. Pappi 6747 (RO); [without exact location] 1906, A. Pappi 6834 (RO); [Gash-Barka region] Mansura [subregion], Beni-Amer, 10 Feb 1909, A. Pappi s.n. (LE); Barca [Baraka] river, 30 Mar 1917, I. Baldrati 230 (FT0007036); Keren, 1300 m, 20 Feb 1919, A. Fiori 975 (FI059443; FT0007025); [Gash Barka Region] Setit, 4 Mar 1923, Exped. Corni-Calciati-Bracciani s.n. (FT0007014); [Northern Red Sea region] Wekiro, 50 ft, 31 Jan 1960, D.J. Greathead 139 (BM);

EтніоріA: [Amhara region] Magdala [Amba Mariam], 27 Apr 1862, Steudner 524 (LE); Ogaden [Region] 1891, L. Robecchi Bricchetti 400 (FT0007010); Addis Ababa, 3 Mar 1916, L. Buscalioni 1415 (FT0007002); [Oromia region, Borena zone] Melka Guba, 1937, G. Cutodontis 130 (W); [Southern Nations, Nationalities, and Peoples' Region] Lago Margherita [Lake Abaya] 21 Jan 1938, A. Vàtova 1582 (FT0007000); [Southern Nations, Nationalities, and Peoples' Region] Gondaraba, 29 May 1939, $R$. Corradi 7107 (FT007088); [Southern Nations, Nationalities, and Peoples' Region] Asile, 1 Jul 1939, R. Corradi 7109A (FT0007087); [Southern Nations, Nationalities, and Peoples' Region] Murle Lake, 18 Jul 1939, R. Corradi 7113 (FT0007085); Somali region, Kelafo, 24 Aug 1960, Anonymous s.n. (K); Addis Ababa to Debre Markos, Blue Nile, 9 Feb 1966, E.F. Gilbert 51 (BR0000018268744, K); [Oromia region, West Shewa zone] Bako, alt. 1650 m, 21 Oct 1969, C. Parker 198 (K); [Gambela 
region, Anuak zone] Gambela, 1768 m, 6 Jan 1970, J.W. Ash 167 (K); Sidamo prov., 1550 m, 2 Mar 1971, J.J.F.E. de Wilde \& M.G. Gilbert 401 (WAG0102276); [Oromia region / Southern Nations, Nationalities, and Peoples' Region] Ziway Lake, Feb 1973, O. Polunin 11584 (K); [Oromia region, Shewa zone] Meki, 6 May 1976, M.G. Gilbert \& T.G. Jefford 4252 (K); [Oromia region, East Welega zone] between Nekemte and Gimbi, 18 May 1976, P.C.M. Jansen 6355 (BR0000018268737, FR0104475, FT0007032, G00350481; MBM369175 - image seen! WAG0181906); [Oromia region, Borena zone] $45 \mathrm{~km} \mathrm{~W}$ of Yavello towards Teltele and Konso, 975 m, 15 Nov 2010, I. Friis et al. 13681 (K, WAG1950295); [Oromia region / Ethiopian Highlands region] Shala Lake, 20 Feb 1979, M.G. Gilbert \& S.B. Gilbert 1173 (K); [Gambela region] $\mathrm{N}$ of Abobo, Alwero river, 650 m, 20 Apr 1982, I. Friis et al. 2476 (K); [Oromia region, Borena zone] $5 \mathrm{~km} \mathrm{~N}$ of Yabelo, $1600 \mathrm{~m}, 11$ Dec 1998, I. Friis et al. 9418 (K, WAG0322893); [Afar region] $10 \mathrm{~km}$ E of Asaita, $400 \mathrm{~m}, 17$ Sep 2001, I. Friis et al. 10345 (K, WAG0394466);

Ghana: [Upper East region] nr Bawku, 12 Dec 1950, C.D. Adams \& G.K. Akpabla 4290 (K, P04576600, WAG0185140); [Northern region] 53 miles N of Tamale, 20 May 1952, J.K. Morton 7200 (K, WAG0185141); [Savannah Region] Yapei, 30 Mar 1956, C.D. Adams 3917 (K); Yeji, 11 Apr 1964, J.B. Hall 1251 (K);

GuineA: [Kouroussa pref.] Kouroussa, Dec 1900, M. Pobeguin 605 (K, P04576530); [Nzérékoré Region] Ouamadou, Dec 1917, J. Berhaut 930 (BR0000018268423); Kankan region, Kankan vill., 23 Apr 1967, S. Lisowski 61907 (BR0000018268508);

KenYa: Makueni county, Kibwezi, 975 m, without date, P. Luke 14330 (K); [Turkana county] Lokitaung, $3000 \mathrm{ft}$, Jan 1932, A.M. Champion 14 (K); [Eastern prov.] Athi plains, 21 Aug 1938, P.R.O. Bally 7442 (K); South province, Magadi Road, 3000 ft, 8 Aug 1943, P.R.O. Bally 2679 (G, K); [Eastern prov.] Athi River Station, 24 Aug 1947, A. Bogdan 1109 (K); [Marsabit county] 16 miles from Laisamis on road to Marsabit, $2500 \mathrm{ft}, 3$ Oct 1947, P.R.O. Bally 5471 (K); [Kajiado county] 1 mile S of Kajiado, 1650 m, 21 Feb 1953, R.B. Drummond \& J.H. Hemsley 1249 (B101143601, BR0000018268799, FT0007096, K); [Lamu county] Witu, [without date] Thomas 127 (BR0000018269000, G); [Taita-Taveta County] Voi, Sala Gate Rd, 1100 ft, 2 Jan 1967, J.G. Greenway 12937a (K); [Turkana county] Ayangyangi swamp, $1900 \mathrm{ft}$, 4 Sep 1968, O.M. Mwangangi \& D. Gwynne 1235 (BR0000018268829, K); Turkana county, between Lothagam and Kerio delta, $1200 \mathrm{ft}, 29$ Aug 1968, O.M. Mwangangi \& D. Gwynne 1218 (K); [Turkana county] Ayangyangi swamp, $1^{\circ} 55^{\prime} \mathrm{N}, 36^{\circ} 5^{\prime} \mathrm{E}, 12$ Jun 1970, B. Mathew \& M.D. Gwynne 6768 (FT0007099, K); North Eastern prov., 57 km WS of Wajir, 225 m, 6 Mar 1974, Bally \& Carter 16590 (K); Mughwango South swamp, 15 Apr 1972, J. Ament \& F.C. Magogo 9 (K); K4, Tana River county, Kora National Reserve, 18 miles from Kora Res. Camp to Asako, 28 Aug 1983, J.G. Mutangah 139 (K); Tana River county, Baomo vill., 30 m, 12 Mar 1990, Q. Luke et al. 141 (K); Embu county, Riakanau, 1125 m, 29 Nov 2000, S.A.L. Smith et al. 253 (K); Isiolo county, Ngare Mara, $0^{\circ} 30^{\prime} \mathrm{N}, 37^{\circ} 39^{\prime} \mathrm{E}, 945 \mathrm{~m}, 12$ Aug 2005, C. Obunyali et al. 261 (K); Machakos county, Kitanga, $1^{\circ} 31^{\prime} \mathrm{S}, 37^{\circ} 11^{\prime} \mathrm{E}, 1660$ m, 26 Jan 2005, J.M. Muasya 482 (K); Marsabit county, Log-Logo, 159'S, 3754'E, 520 m, 9 Feb 2005, 
J.M. Muasya et al. 505 (K); [Coast prov.] Tana delta, 2²4'S, 40¹8'E, 5 m, 4 May 2011, C. Leauthaud et al. 160 (K);

Malawi: Nsessi, Dec 1887, L. Scott s.n. (K); Malawi Lake, 1893-1894, G.F. Scott Elliot 8403 (K); [Southern region] Mulanje, 16 Nov 1955, G. Jackson 1761 (BR0000018269536, K); Central region] Ncheu, 29 Sep 1970, A.J. Salubeni 1491 (K); Central Region, Ntchisi Distr., 1060 m, 20 Jun 1970, R.K. Brummitt 11583 (K); Northern region, Karonga Distr., Kaporo, 1550 ft, 2 Jan 1974, J. Pawek 7726 (K); [Southern region] Mangochi Distr., Lake Malawi, 22 Dec 1984, I.H. Patel et al. 1736 (K); [Northern region] Nkhata Bay Distr., S of Mbuzi Hill, 24 Aug 1984, A.J. Salubeni \& W.Nachamba 3875 (K); [Central region] Salima Distr., Lifidzi breeding centre, 17 Nov 1985, I.H. Patel \& R.B. Kwatha 2898 (K); Southern region, Phalombe, 15\%46'47"S, 3548'44"E, 721 m, 15 Apr 2008, H.T. Chapama et al. 830 (K);

Mali: [Sikasso region] Zamblara, 16 Jun 1899, A. Chevalier 991 (P04576672); [Niger Delta region] Djenné, 30 Jun 1899, A. Chevalier 1129 (P04576675); [Mopti region] Mopti, Niger river, 15 May 1927, O. Hagerup 72 (K); [Timbuktu region] Timbuktu, Jun 1927, O. Hagerup 123a (LE); [Ségou Region] Macina [The Inner Niger Delta], 14 May 1932, O.B. Lean 14 (K); [Mopti region] Dallah, 19 Jun 1932, J. Rogeon 388 (P04576669); [Mopti region] Sangha, 14 Jan 1938, S. de Ganay 73 (P04576552); [Mopti region] Saré Dina, 25 Mar 1952, J.T. Davey 62 (K); [Mopti Region] Dogo, 7 May 1952, J.T. Davey 102 (K); [Ségou Region] Kara, 15 Jul 1954, J.T. Davey 192 (K); [Timbuktu region] nr Timbuktu, 6 Aug 1959, G. Popov 90 (BM); [nr Bamako] Korofina, 26 Feb 1960, J. Raynal \& A. Raynal 5514 (P04576662); [Sikasso region] Sanzana, 3 Apr 1970, N. Diarra 590 (P04576520); [Timbuktu region] Ngoro, nr Niafunké, 20 Jan 1991, A. Raynal-Roques 23030 (P04576559); [Koulikoro Region] Koulikoro, Niger river, 6 May 1993, R. Ehrlich 463 (B100048300); Kayes region, Comitradougou, $100 \mathrm{~km}$ from Diéma, $1^{\circ} 25^{\prime} \mathrm{N}, 8^{\circ} 18^{\prime} \mathrm{W}$, alt. $317 \mathrm{~m}, 25$ Feb 2006, $R$. Dembele et al. $M L-283$ (K001394833);

Mauritania: Tagant region, May 1937, A. Chevalier s.n. (P04576594); Nouakchott, 13 Feb 1957, J.G. Adam 12980 (P00695348); [Gorgol region] between Kaédi and Mbout, 14 Jun 1960, M. Mosnier 590 (P04576667); [Gorgol region] Rinndiao, 16 Oct 1972, A. Naegele 86 (K); [Trarza region] R'Kiz Lake, 15 Sep 1975, D. Dupont s.n. (BR0000018268485); Tagant region, $32 \mathrm{~km}$ SE of Tidjikja towards El Khedia, 25 Oct 1987, M. Carriere et al. 85209 (K);

Mozambique: Gaza prov., 25 km from Vile de João Belo [Xai Xai], 7 Oct 1925, G. Pedro 218 (K); Sofala prov., Gorongosa NP, 12 Oct 1944, F.A. Mendonça 2458 (K); Tete prov., Mazowe River, 1000 ft, 22 Sep 1948, H. Wild 2598 (K); Tete prov., Ilha Micune, 19 Jun 1949, L.A. Grandvaux Barbosa \& F. de Lemos 3187 (K); Gaza prov., Guija, between Aldeia do Guija and Aldeia da Barragem, 15 Nov 1957, L.A. Grandvaux Barbosa \& F. de Lemos 8141 (K); [Gaza prov.] between Chibuto and Canicado, 11 Oct 1957, L.A. Grandvaux Barbosa \& F. de Lemos 8001 (K); [Faza prov.] Sul do Save, Chibuto-Baixo Changana, 24 Aug 1963, A. Macedo \& L. Macuacua 1139 (K); Lorenço Marques [Maputo] prov., Namaacha, 5 Jul 1967, A. Marques 2043 (WAG1103167); Gaza prov., Caniçado, 23 Aug 1969, M.F. Correia \& A. Marques 
1181 (E, WAG1103169); [Sofala prov.] Gorongosa NP, Jul 1970, K.L. Tinley 1938 \& 1941 (BR0000018269178, M, WAG1103228); Gaza prov., Limpopo river, 2 Aug 1973, M.F. Correia \& A. Marques 3156 (WAG1103171); [Tete prov.] Cahora Bassa, 2 Nov 1973, M.F. Correia \& al. 3700 (WAG1103172); [Sofala prov.] Gorongoza NP, 9 Nov 2007, P. Ballings \& B. Wursten 945 (BR581201); Cabo Delgado prov., Ruvuma, 15 Nov 2009, Q. Luke 13804 (K, P04557299);

Namibia: Waterberg region, Quickborn, 28 Oct 1928, R.D. Bradfield 301 (K); [Kunene Region] Omuramba to Otamako, 27 Feb 1939, O. Volk 1201 (M); [Khomas Region] Windhoek, Adodamm, Jan 1947, Wiss 826 (M); [Erongo region] Brandberg, Ugab river, 8 Aug 1948, R.G. Stray 2407 (K, PRE0403677); [Erongo region] Kuiseb river, nr Homeb, 11 Oct 1961, W. Giess 3762 (M); [Kunene region] Kaokoveld, Kunene river, $17^{\circ} 15^{\prime}$ S, $12^{\circ} 16^{\prime E}$, 16 Aug 1956, R. Story 5826 (K, PRE0403678); [Karas Region] Sendlingsdrif, Orange river, Aug 1963, H. Merxmüller \&W. Giess 3259 (M); [Otjosondjupa region] Otjosondu, Omusema river, 1300 m, 10 Mar 1967, R. Seydel 4495 (B101143620, K, M, PRE0614464); [Karas Region] Lüderitz-South distr., Sendlingsdrif, 21 Sep 1972, H. Merxmüller \& W. Giess 28689 (M, PRE0403676, WAG1103212); [Khomas Region] Windhoek, Farm Regenstein, Dec 1979, W. Giess $15418(\mathrm{M})$;

Niger: [Zinder region] Tasker, [without date] P. de Fabregues 8834 (P04557298); [Tahoua region] Madaoua, Feb 1932, A. Chevalier 43716 (PP04576596); [Tilaberi Region] Dolbel, 24 Oct 1962, J. Jangoux 1214 (BRLU0026263); [Agadez Region] $19^{\circ} 18^{\prime} \mathrm{N}, 7^{\circ} 15^{\prime} \mathrm{E}, 4$ Dec 1965, C.F. Hemming s.n. (K); [Agadez region] Touaret, $20^{\circ} 20^{\prime} \mathrm{N}, 07^{\circ} 00^{\prime} \mathrm{E}, 10$ Dec 1965, G. Popov 138 (BM); [Diffa region] Bosso, 20 Jun 1966, J.P. Lebrun 13836 (P04576587); [Agadez region] Iferouane, $19^{\circ} 10^{\prime} \mathrm{N}, 08^{\circ} 30^{\prime} \mathrm{E}$, 3000 ft, 22 Jan 1970, R.A.H. Davies 32 (BM); [Tahoua region] Abalak, 12 Jan 1975, P. Lavie 870 (P04576521); [Agadez region] Iferouane, 17 Mar 1979, Dulieu 49673 (P04576588); [Agadez region] Azanyares, $18^{\circ} 9^{\prime} \mathrm{N}, 9^{\circ} 17^{\prime} \mathrm{E}, 19$ Mar 1979, J.E. Newdy ZP64 (K); [Agadez region] Tarouadji, 30 Mar 1980, E. Schulz s.n. (B101143619); [Agadez region] $100 \mathrm{~km} \mathrm{~S}$ of Agadez, 23 Nov 1985, C. Pase 3149 (K); Niamey, 11 Apr 1987, N. Leman 83 (BR0000018268515); [Tilaberi region] Tapoa zone, West Niger NP, 7 Apr 1996, H. Breyne 6186 (BR0000018268522, WAG0330951);

NigERIA: [Benue State] Abinsi, 1912, J.M. Dalziel s.n. (BM, BR0000018268539, P04576604); [Kwara State] Jebba, 9 Dec 1927, O. Hagerup 699 (K); [Bauchi State] Bauchi, Feb 1929, H.V. Lely 144 (K, P04576593); [Sokoto State], Sokoto, 20 Apr 1946, R. W.J. Keay 15877 (K); [Yobe State] Gashua,8 miles E of Zurmi, bed of Fafara river, 21 Jun 1947, C.F. Onochie 23365 (K); [Niger State] 10 miles N of Bussa, Shagunu, $10^{\circ} 20^{\prime} \mathrm{N}, 4^{\circ} 25^{\prime} \mathrm{E}, 25 \mathrm{Jul}$ 1965, C.D.K. Cook 408 (K); [Niger State] Bida distr., at the bank of Niger river, 1 Mar 1968, B.O. Daramola \& A. Binuyo 61946 (K); [Zamfara State] Kaura Namoda area, 22 Jul 1969, M.G. Latilo 62605 (K); [Taraba State] Sardauna, nr Gashaka, 25 Mar 1970, J.B. Hall 1577 (K); [Taraba State] Gashaka distr., Gashaka river, alt. 1100 ft, 25 Mar 1970, Z.O. Gbile \& B.O. Daramola 23888 (K); [Niger State] Kainji Lake, 21 Jul 1973, R. Linnavuori s.n. (H1209977); [Kwara State] 
nr Jebba, 15 May 1974, Latilo et al. 69359 (K, WAG0185138); Borno State, Maiduguri, E. Denys 740 (BR0000018268553, WAG0104167); Borno State, Gajiganna, 23 Feb 2004, S. Kahlheber 1082 (FR-0034796);

Senegal: [without exact location] May 1825, Roger 66 (K); [without exact location and date] Perrottet s.n. (RO); [without exact location and date] herb. Maire s.n. (RO); Galam, [without date and collector] s.n. (P04577294); [Saint Louis region] Richard Toll [village], 26 Feb 1965, G. Roberty 16845 (G); Djibelor, 17 May 1982, C. Vanden Berghen 4987 (BR0000018268478);

Somalia: Somaliland, $75 \mathrm{~km} \mathrm{~S}$ of Hargeisa, near Dofar, 19 Oct 1954, P.R.O. Bally 10115 (G); [Lower Juba prov.] Jubbada Hoose, Badana Lake, ca. 75 km WSW di Chisimaio, 0³2'S, 41 $58^{\prime}$ 'E, 28 Oct 1971, G. Moggi \& R.Bavazzano s.n. (K); [Shabeellaha Dhexe prov.] Mahaddey Uen [Mahadday Weyne], 13 Mar 1975, R. Bavazzano 442 (FT0007076); [Lower Shebelle prov.] Afgooye-Merca road, 18 Mar 1975, R. Bavazzano 486 (FT0007077); Middle Juba prov., Buale to Baardheer, 29 Jun 1978, S.M.A. Kazmui \& al. 777 (WAG0338795); [Middle Shabelle region] $35 \mathrm{~km}$ N from Jowhar, 14 Oct 1983, P. Kuchar 15319 (K); [Middle Shabelle Region] Jowhar, 2007, A. Sheik $A 2007(\mathrm{~K})$;

South Africa: [Western Cape prov.] Cape of Good Hope, [without date] Drège s.n. (P04576613); [Limpopo prov.] Messina [Musina], [without date] F.A. Rogers 19446 (G, Z-000092197); River Limpopo, nr Messina [Musina], 27 May 1927, R.G.H. Young 14664 (BM); [Zululand] Ubombo, Mkuzi Game Reserve, 100 m, 9 Dec 1959, C.J. Ward 3352 (K, M, PRE0403692, W); [KwaZulu-Natal prov.] Ingwavuma Distr., 12 May 1965, Vahrmeyer \& Tölken 977 (K, PRE0403694, STU); [KwaZuluNatal prov.] Ingwavuma, 11 Jul 1974, H. Furness 97 (E); [Limpopo prov.] Soutpansberg, Limpopo river, 4 Apr 1983, C. Straub 173 (PRE0653966); Limpopo prov., nr Kruger NP, 350 m, 24 Nov 2000, N.H.G. Jacobsen 2431 (BR945920);

South Sudan: [Upper Nile State] bank of the Khor Geyni, Pibor river, 4 Jun 1929, N.D. Simpson 7032 (K); Jonglei State, 8 km S of Maar, alt. 450 m, 18 Feb 1980, J.M. Lock 80/26 (K);

Sudan: Khartoum, 1860, Hartmann s.n. (LE); [River Nile State] Shendi, 25 Oct 1868, K. Schweinfurth 736 (K); "Kordofan" [former province], Dec 1878, Exp. Prout 467 (P04577103); Darfur [Region], Jan 1879, Anonymous 84 (K); [White Nile State] Ed Dueim, 10 Jan 1906, P.L. de Vilmorin s.n. (BR0000018268720); Khartoum, 11 Jan 1933, G. Aylmer 275 (K); Kassala State, Tokar delta, 17-23 Nov 1936, F.W. Andrews A220 (K); [Gadaref State, south of Hawata town], Huweishrat el Qardud forest, 16 Apr 1961, J.K. Jackson 4143 (K); Northern State, Wadi Halfa, 29 Sep 1962, A. Pettet 71 (BR0000018268652, K); Kassala State, Ashkeit, 9 Oct 1962, T. Ahti 16731 (K); Khartoum, Buni, 30 Jan 1963, A. Pettet 107 (K, P04577283); [West Darfur State] Jebel Marra, Zalingei, alt. 3400 ft, 7 Feb 1964, G.E. Wickens 1193 (K); [Central Darfur State] Zalingei, Wadi Aribo, 18 Jan 1965, W.J.J.O. de Wilde et al. 5348 (WAG1103211); Khartoum, 12 Mar 1965, W.J.J.O. de Wilde et al. 5836 (BR0000018268713, WAG1103209); North Darfur, Wadi Magrur, 8 Dec 1991, N. Altmann 347 (B100597466); 
TanZania: Kilimanjaro, $1000 \mathrm{ft}$, Jan 1894, G. Volkens $1642(\mathrm{G})$; [Rukwa region] Rukwa Lake, [years] 1898-1900, W. Goetze 1109 (BR0000018268836, G, L1693136, P04577300); [Morogoro region] Kilosa, 28 Dec 1921, C.F.M. Swynnerton s.n. (BM); [Dodoma Region] Kondoa distr., 8 Jan 1928, B.D. Burtt 1869 (K); [Tanga / Manyara regions] Mgera to Kibaya, 1500 m, 23 Aug 1932, Geilinger 1589 (K); [Dodoma region] Mpwapwa to Gulwe, H.E. Hornby 390 (K); [Iringa Region] Ilula, 24 Oct 1932, Geilinger 3292 (K); [Lindi region] $40 \mathrm{~km} \mathrm{~W}$ of Lindi, Lutamba Lake, 3 Oct 1934, H.J. Schlieben 5427 (BM, BR0000018268959, G, M, P04576499); [Shinyanga / Tabora regions] Shinyanga-Nzega distr., Manyonga river, $3500 \mathrm{ft}$, Oct 1935 , B.D. Burtt 5232 (BM, BR0000018268997, K); [Iringa region] Idodi, Oct 1936, E. Ward 29 (K); [Morogoro region] Morogoro distr., Nov 1949, S.R. Semsei 2868 (BR0000018268867, BR0000018268874, K); [Kilimanjaro region] Mwanga, 18 Aug 1951, R.E.S. Tanner 393 (K); [Dodoma Region] Mpwapwa, 3000-3500ft, 3 Nov 1951, H.E. Hornby 390 (K); [Arusha Region] between Arusha and Moshi, $3500 \mathrm{ft}$, 23 Sep 1952, P.R.O. Bally 8325 (K); [Tanga Region] Lushoto distr., 1 May 1953, R.B. Drummond \& J.H. Hemsley 2346 (B101143608, FT0007097, K); Rukwa Region, Rukwa, 2800 ft, 4 Dec 1954, H.M. Richards 3516 (BR0000018268928, K); [Pwani region] Ruifiji distr., Utete, 2 Dec 1955, E. Milne-Redhead \& P. Taylor 7460 (B101143606, BR0000018269024, K); [Katavi region] Mpanda distr., Kibwezi, 3000 ft, 20 Aug 1958, J. Newbould \& T. Jefford 1687 (K); [Rukwa region] Rukwa, 21 Oct 1959, H.M. Richards 11517 (K); Dodoma region] Mtera, 19 Apr 1962, Polhill \& Paulo 2077 (B101143604, BR0000018268904, K); [Manyara region] Mbulu distr., Lake Manyara NP, 5 Mar 1964, P.J. Greenway \& Kanuri 11306 (K); Tanga Region, Korogwe distr., 17 Sep 1965, Semsei 3985 (K); [Manyara region] Tarangire NP, 914 m, 29 Nov 1969, M. Richards 24827 (K); [Dodoma region] nr Dodoma, 3000 ft, 16 Dec 1969, W.J. Mapunda \& M.D. Raya 1051 (K); [Arusha region] Engaruka valley, $3530 \mathrm{ft}$, Oct 1970, H.M. Richards \& S. Arasululu 26638 (BR0000018268942, K); [Iringa region] Ruaha NP, 2700 ft, 21 Oct 1970, H.M. Richards \& Arasululu 26297 (K); Arusha Region, Masai distr., Magadini vill., 700 m, 8 Aug 1974, B. Mhoro \& I. Backeus 2028 (K); [Arusha region] Ngorongoro Conservation area, 1 Oct 1977, J. Raynal 19326 (BR0000018268881, K, P04576664); Morogoro region, Mikumi NP, 500 m, 16 Oct 1986, A. Borbidi et al. 86150 (K) ; [Kigoma region] Kigoma distr., 22 Aug 1988, anonymous $1687(\mathrm{~K})$; [Kilimanjaro region] between Moshi and Himo, 920 m, 3 Feb 1996, A. Hemp 945 (P000869013);

Note. Plants of both specimens of Glinus lotoides and G. oppositifolius are present on the same herbarium sheet (Tanzania, Polbill \& Paulo 2077, K).

Uganda: [Nakapiripirit distr.] Kakamongole, at base of Mt Debasien, Jan 1936, W.J. Eggeling 2607 (BR0000018268768, K); Karamoja [sub-region], Kidepo river, $3400 \mathrm{ft}$, Apr 1960, J. Wilson 986 (BR0000018268775, K);

Zambia: Lunsemfwa river, 24 Apr 1929, J. Burtt Davy 897 (K); [Southern prov.] Makambola Farm, Mazabuka, 3300 ft, 28 Apr 1931, C.F. Trapnell 345 (K); [Eastern prov.] Nsefu Game Camp, 750 m, 15 Oct 1958, N.K.B. Robson 138 (K); [Eastern 
region] Luangwa valley, $13^{\circ} \mathrm{S}, 32^{\circ} \mathrm{E}, 2000 \mathrm{ft}, 29$ Nov 1957, Stewart 70 (K); [Eastern prov.] Luangwa Game Reserve, Chilongozi Pontoon, 600 m, 11 Oct 1960, H.M. Richards 13333 (K); Zambesi river, Feira [Luangwa], 27 Sep 1962, A. Angus 3350 (K); [Southern prov.] Mazabuka, 2 Oct 1963, H.J. van Rensburg 2515 (K);

Zimbabwe: [Mashonaland] East prov., Mutoko, Mkota Reserve, $1600 \mathrm{ft}, 1 \mathrm{Oct}$ 1948, H. Wild 2676 (BR0000018269147, K); [Masvingo prov.] Nuanetsi, nr Malipati, 2 May 1961, R.B. Drummond \& R.O.B. Rutherford-Smith 7676 (K); [Matabeleland North prov.] Siabuwa, 2500 ft, Oct 1955, R.M.Davies 1385 (K); [Mashonaland East prov.] Mutoko Distr., Nyangombe river, 1600 ft, 1 Oct 1948, H. Wild 2676 (K); [Masvingo prov.] Chiredzi, 31 May 1971, J.F. Ngoni 147 (K); [Mashonaland West prov.] Lake Kariba, Kessessee Bay, 483 m, 5 Aug 1983, P. Denny 1215 (L0717097);

General distribution. Africa (Cape Verde, North African countries, Seychelles, Madagascar, Mauritius); W, S \& SE Asia; Australia. The distribution in North America is not confirmed in our study.

\section{Glinus oppositifolius (L.) Aug.DC., Bull. Herb. Boiss., ser. 2, 1: 559 (1901).}

三 Mollugo oppositifolia L., Sp. Pl. 1: 89 (1753). Holotype: Sri Lanka. P. Hermann in Herb. Hermann 1: fol. 20 (BM000621295!).

Description. Annual, branched from the base, with numerous prostrate stems often forming mats up to $1 \mathrm{~m}$ in diameter; young parts of the stems covered with simple crispate hairs usually arranged along one line; prickles absent or unnoticeable with the naked eye. Leaves rosulate, short-lived, and cauline, green, glabrous or puberulent, shortly petiolate (petioles 3-10 mm long), entire or coarsely denticulate, oblong, ovate, obovate or narrowly obovate, (10)15-45(55) $\mathrm{mm} \times 3-15(20) \mathrm{mm}$, apically shortly acuminate, lateral veins neither recessed adaxially nor prominent abaxially. Flower clusters interrupted, consisting of (1)2-10 flowers, rarely more; flowers usually with unequal pedicels 7.0-20.0 mm long, or sometimes (sub)sessile; buds and closed anthocarp of cylindrical shape. Perianth segments in flowering (2.7)3.0-3.5 mm long, in fruiting (3.5)4.0 $5.0(5.5) \mathrm{mm}$ long, glabrous or sparsely pubescent, dorsally green or pink with white margins and ventrally white or pinkish, sometimes turning red at senescence; petaloids usually absent. Stamens usually 5, rarely 4 or 6-7; anthers (03.-0.5)0.6-0.8(1.0) mm long. Stigmas 3, 0.3-0.6 mm long. Seeds reddish or brown-red, rarely yellow-brown, $0.30-0.50 \times(0.25) 0.3-0.4 \mathrm{~mm}$, colliculate or rarely smooth, longitudinal ridges absent.

Note. Glinus oppositifolius is sometimes confused with Gisekia pharnaceoides L. (Gisekiaceae). The most remarkable characters of Gisekia are the leaves and perianth with white striae (formed by cells with raphides), and its capsules are divided into 5-15 mericarps each containing one exarillate seed (Gilbert 1993b). In contrast to Gisekia, Glinus species do not have easily visible raphides in any part of the plant and their capsules are multi-seeded with arillate seeds. 


\section{Key to the varieties}

1 Flowers (1-10 in a cluster, rarely more) with pedicels 7.0-20.0 mm long G. oppositifolius var. oppositifolius

- $\quad$ Flowers often sessile or with short pedicels up to $5.0 \mathrm{~mm}$.................................2

2 Upper part of stems \pm lanate; leaves up to $15.0 \mathrm{~mm}$ long; clusters with less than 10(15) flowers G. oppositifolius var. keenanii

- Stems glabrous or sparsely hairy; leaves often longer than $15.0 \mathrm{~mm}$; clusters with $10-20$ or even more flowers G. oppositifolius var. glomeratus

\section{Glinus oppositifolius var. oppositifolius}

Figs 22, 23

= Mollugo spergula L., Syst. Nat., ed. 10, 2: 881 (1759).

E Pharnaceum mollugo L., Mant. Pl. Altera: 561 (1771), nom. illeg.

三 Glinus mollugo Fenzl, Ann. Wiener Mus. Naturgesch. 1: 359 (1836), nom. illeg.

三 Glinus spergula (L.) Steud., Nomencl. Bot., ed. 2, 1: 668 (1840). Lectotype (Jeffrey, 1961: 15): [without location, date and collector] Herb. Linnaeus 112.3 (LINN image seen!)

= Pharnaceum parviflorum Roth, Nov. Pl. Sp.: 186 (1821) 三 Mollugo parviflora (Roth)

Ser. in DC., Prodr. 1: 391 (1824). Holotype: India. B. Heyne s.n. (B† destroyed). = Physa madagascariensis DC., Prodr. 1: 393 (1824). Type: Madagascar. A. du Petit-

Thouars (P?, not found). Note. This plant was originally described by du PetitThouars (1806) as a monotypic genus without any species assigned. De Candolle (1824) named the species with a reference to the protologue of the generic name, without any new material involved. The type of Physa madagascariensis is therefore a specimen collected in Madagascar by Petit-Thouars and presumably deposited at $\mathrm{P}$. = Mollugo denticulata Guill. \& Perr., Fl. Seneg. Tent. 1: 45 (1833).

三 Glinus denticulatus (Guill. \& Perr.) Fenzl, Ann. Wiener Mus. Naturgesch. 1: 361

(1836). Lectotype (Jeffrey 1961: 15, as holotype): Senegal. 1831, [G.S.] Perrottet s.n. (P04577215! isolectotypes - BM, G00414309!).

= Mollugo subserrata Blanco, Fl. Filip. [F.M. Blanco]: 51 (1837). Holotype: Philippines. [without date] Blanco 385 (BM!).

= Mollugo glinoides A.Rich., Tent. Fl. Abyss. 1: 48 (1847), nom. illeg., non Cambess. (1830). Type: Ethiopia. Shire, Quartin-Dillon s.n. (P, n.v., after Jeffrey 1961: 15). = Mollugo serrulata Sond., Linnaea 23(1): 15 (1850).

E Glinus mollugo var. natalensis Sond. in Harvey \& Sonder, Fl. Capensis 1: 120 (1860). Lectotype (Jeffrey 1961: 15): South Africa. [Kwa-Zulu] [Port of] Natal [Durban], Gueinzius 138 (S, isolectotype G!). Note. The type of Mollugo serrulata was not labelled by Sonder at G or S. In the latter collection it is stored under Mollugo sp. The specimen seen at $\mathrm{G}$ is a typical G. oppositifolius with serrulate leaves. 

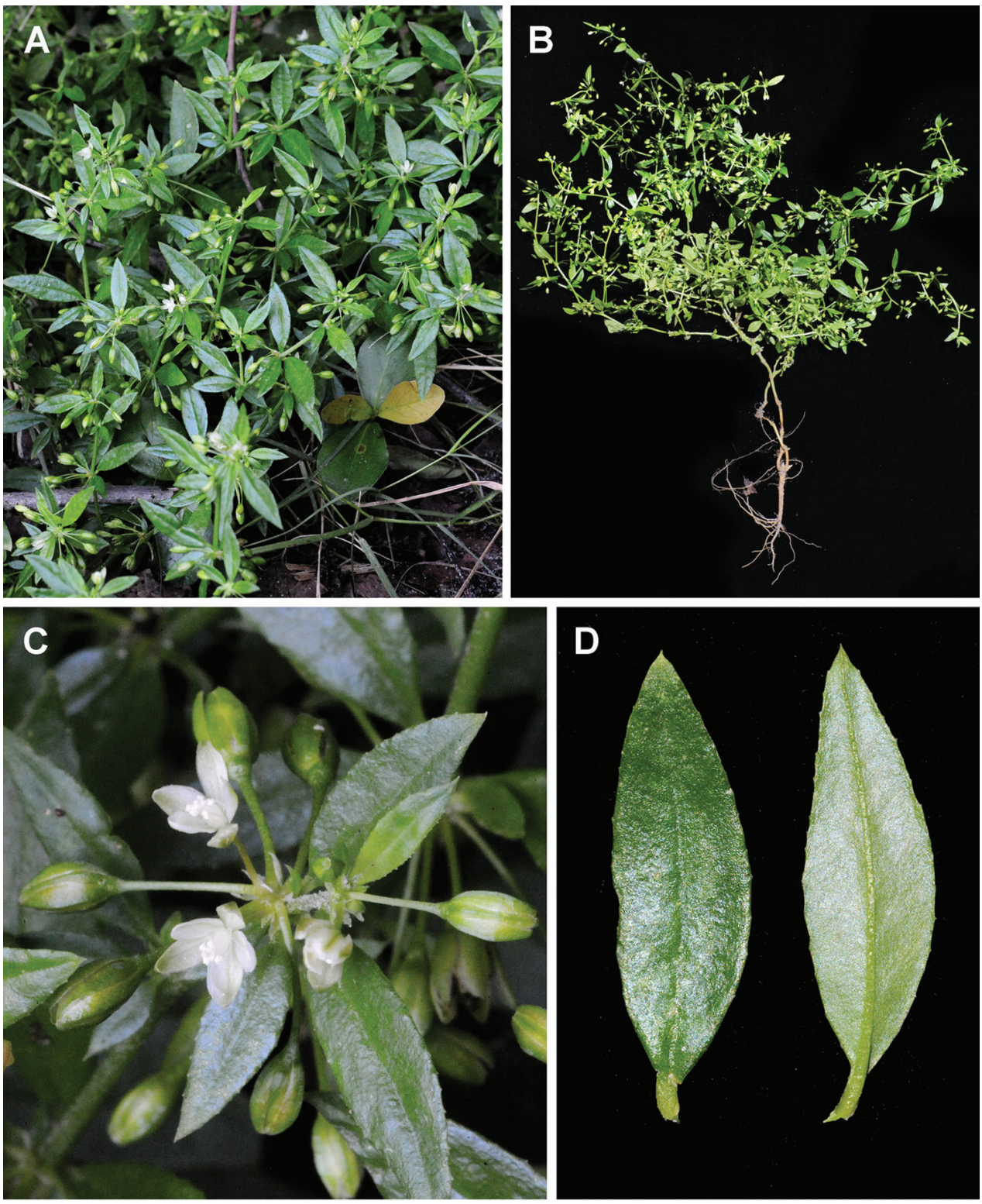

Figure 22. Glinus oppositifolius var. oppositifolius $\mathbf{A}, \mathbf{B}$ general view of the plant $\mathbf{C}$ close-up of the flowers D close-up of the leaves. Photographers - Roger and Alison Heath (Moremi Game Reserve, Ngamiland, Botswana, 07 Feb 2011).

= Mollugo novo-hollandica F.Muell., Trans. Philos. Soc. Victoria 1: 14 (1855). Described from Australia (banks of the Murray River). Type: n.v.

= Wycliffea obovata Ewart \& A.H.K.Petrie, Proc. Roy. Soc. Victoria, n.s. 38: 167 (1926). 
Described from Wycliffe (Northern Territory) and Stirling Station (surroundings of Perth) (Ewart and Petrie 1926). Type n.v. (MEL?). Note. The protologue of this species as well as the drawings (figure 1) completely correspond with G. oppositifolius, although the seed characters of W. obovata were not described.

= Glinus oppositifolius var. parvifolius Hauman, Bull. Jard. Bot. État Bruxelles 19: 446 (1949). Holotype: Congo Belge [Dr Congo], Kwango [prov.], July 1913, Vanderyst 1417 (BR000000895568!). Note. Plant with closely set and shorter (up to 10 $\mathrm{mm})$ leaves.

Habitat. Sands, river banks or as a weed; altitude up to $1600 \mathrm{~m}$ a.s.l. The most common variety in Sub-Saharan Africa. The associated plants found in Botswana (A. Heath \& R. Heath 456, K): Cynodon dactylon, Sida cordifolia, Glinus bainesii, G. hirtus, Portulaca oleracea, Cyperus polystachyos, C. compressus, C. longus, Pseudognaphalium luteoalbum (formerly known as Helichrysum luteo-album). Flowers mostly during the main rains (in southern Africa).

Distribution (Fig. 24). Angola: [Bengo prov.] Barra do Bengo distr., Sagoa, Dec 1853, F. Welwitsch 1265 (BM); [Luanda prov.] between Camama and Calumbo, Jul 1854, F. Welwitsch 1110 (BM); Luanda distr., between 8 and 9 $9^{\circ}$, Jan 1858, F. Welwitsch 2409 (BM, LE); [Bengo prov.] Barra do Dande distr., Dande river, Sep 1858, F. Welwitsch 1112 (BM); [Zaire prov.] Tombe, 1908, H.A. Junod 2886 (BM); Luanda, Muceque, Mar 1914, J. Gossweiler 5880 (COI00070554); Luanda, 1918, K. Müller 1109 (G); [Kwanza Sul / Bengo provinces] Catemba to Muceque, 60 m, 30 Sep 1935, J. Gossweiler 10405 (BM); [Bengo prov.] Calemba, 60 m, 30 Sep 1935, J. Gossweiler 10405 (BM, COI00070555);

Benin: Porto Novo, 6 Mar 1910, A. Chevalier 23314 (P04577130); Cotonou, 19 Jan 1962, D. Froment 1141 (BR0000018269932); Ouémé [dept.], Bonou, 12 Mar 1998, P. Houngnon 5608 (BR0000018269949, K); [Collines dept.] Dassa, 4 Nov 1998, V. Adjakidjè et al. 2189 (BR0000018269956, K, WAG0095242); Zou [dept.], Djidja, 11 Feb 1999, J.-P. Essou et al. 1251 (WAG0235854); [Kouffo dept.] Klouékanmé, 15 Feb 1999, J.-P. Essou et al. 1340 (WAG0235856); Borgou dept.], Tchaourou, 7 Apr 1999, A. Akoegninou et al. 2258 (WAG0235860); [Alibori dept.] Malanville, 28 Apr 1999, P. Houngnon et al. 6545 (WAG0235849); Mono dept., Athiémé, 3 Jul 1999, N. Sokpon et al. 838 (WAG0235853); Zou dept., Cové, 14 Jul 1999, P. Houngnon 6798 (WAG0235850); [Donga dept.] Bassila, 20 Apr 2000, P. Houngnon 7634 (WAG0235851); [Collines dept.] Savalou, 9 Jun 2000, V. Adjakidjè 3595 (WAG0235859); Atakora dept., Natitingou, 28 Jun 2000, N. Sokpon 1610 (WAG0317484); Mono dept., Comé, 14 Aug 2000, V. Adjakidjè 3750 (WAG0235874);

Botswana: Northern distr., Mutsoi, 9 Nov 1967, F.L. Lambrecht 420 (K, PRE0403655); Ngamiland distr., Okavango swamp, 25 Feb 1973, P.A. Smith 449 (K, PRE0521257); [Central distr.] Boteti river, 20²3'75"S, 24²31'4"E, 15 Feb 1980, P.A. Smith 3031 (PRE0671278); [North-West distr.] Okavango delta, Maun, 15 May 1984, P.A. Smith 4443 (BR0000017454513, K); [Ngamiland distr.] Zi- 


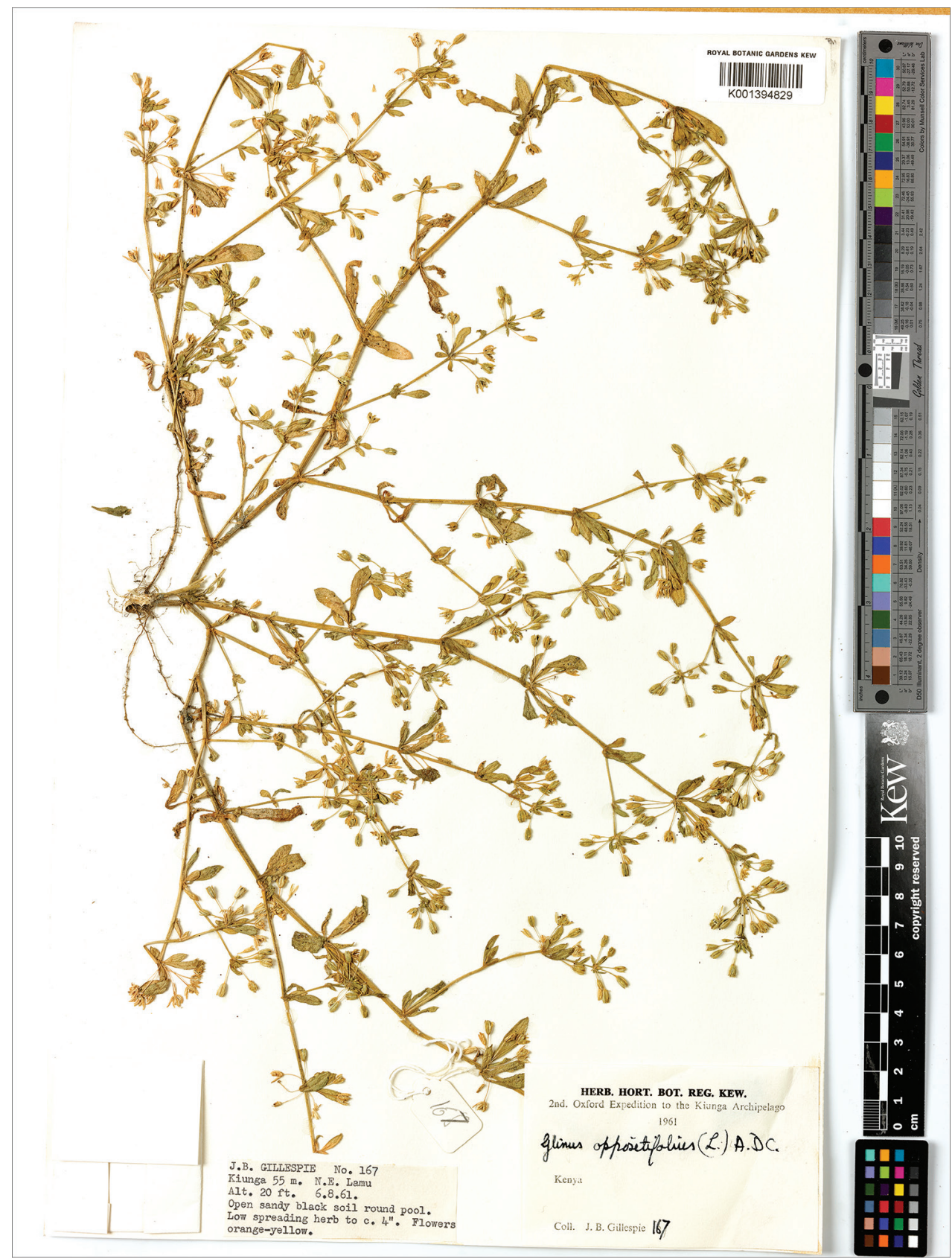

Figure 23. A herbarium specimen of Glinus oppositifolius var. oppositifolius (Kenya, [Lamu county], Kiunga, 55 m NE Lamu, 6 Aug 1961, J.B. Gillespie 167, K001394829). Copyright of the Board of Trustees of the Royal Botanic Gardens, Kew. 
balianja lagoon, $18^{\circ} 34.7^{\prime} \mathrm{S}, 23^{\circ} 32.15^{\prime} \mathrm{E}, 957 \mathrm{~m}, 23 \mathrm{Jan} 2004$, A. Heath \& $R$. Heath 456 (BACH, K);

Burkina Faso: Oudalan prov., Oursi, 22 Sep 1995, S. Kahlheber 145 (FR0014454); Oudalan prov., Yomboli, 24 Jul 1999, J. Müller 86 (FR-0014433); Oudalan prov., Darkoye, 8 Aug 1999, J. Müller 142-c (FR-0024423); Kompienga prov., $11^{\circ} 09^{\prime} 39^{\prime \prime N}, 0^{\circ} 37^{\prime} 24 " \mathrm{E}, 203 \mathrm{~m}$, M. Schmidt 720 (FR-0021934); Ouagadougou, 8 Jun 1987, J. Lejoly 87/020 (BRLU0026274);

Burundi: Bujumbura, 800 m, 29 Oct 1968, J. Lewalle 3076 (BR0000017455862); Bujumbura, 800 m, 28 Sep 1971, J. Lewalle 6144 (G, WAG0104163); Bubanza prov., Randa, 950 m, 25 Sep 1976, M. Reekmans 5325 (BR0000017455909, H1235324, K, WAG0185122);

Cameroon: [Southwest region] Mamfe, on the sandbanks by the Cross river, 15 Mar 1953, C.F.A. Onochie et al. 30889 (K); [Littoral region] nr Masok, Ouem river, 4 Apr 1965, A.J.M. Leeuwenberg 5378 (BR0000018269987, K, P04577247, WAG0185118); [Littoral prov.] 45 km SE of Yabassi, 18 Jan 1972, R. Letouzey 11022 (BR0000018270006, P04577207, WAG0185121); [Littoral prov.] Mbombe river, $20 \mathrm{~km}$ W of Yabassi, 1 Mar 1976, R. Letouzey 14779 (BR0000018269994, K, P04577210, WAG0185120);

ChaD: [Chari-Baguimi region] Mailao, 1 May 1966, Stauch 23 (P04577261); [Chari-Baguimi region] between Djimtilo and Lake Chad, 31 Jan 1968, J. Léonard 4445 (BR0000017456012, G, K, M, P04577268, PE01696734, WAG1103324); [Chari-Baguimi region] Ouazkaga, 27 May 1971, G. Fotius 1938 (P04577255); Sarh, 7 Jun 1975, Palayer 605 (P04577265);

DR Congo (selected): [Kwilu prov.] Wombali, Nov 1910, Vanderyst s.n. (BR0000013706029); [Province of Équateur] Bokala, Anonymous 4777 (BM); [Congo Central prov.] Boma, Congo river, 27 Sep 1913, Bequaert 804 (BR0000017454537); [Kongo Central prov.] Matadi, Nov 1913, Verschueren 920 (BR0000017455060); [Orientale prov.] Laga, 10 May 1914, J. Gossweiler 5880 (BM); Leopoldville [Kinshasa], Jul 1915, L. Achten 17 (BR0000017454667); Bas-Congo [Congo Central prov.], 1921, J. Claessens 27 (BR0000017454568); [Shopo province] Stanleyville [Kisangani] 25 Jan 1926, W. Robyns 1418 (K); [Province of Équateur] Bamania, 1930, J. Lebrun 884 (K); [Congo Central prov.] Boma, 4 Nov 1930, Vanderyst 27235 (BR0000017454612); [Orientale prov., Tshopo distr.] Yangambi, 6 Jun \& 12 Jul 1938, J. Louis $9711 \& 10313$ (BM, BRLU0026266, K, P04577193, U1398742); [Province of Équateur] Eala, 5 Aug 1946, J. Léonard 240 (ALCB012594-image seen! FT0007107, K, P04577194); [Kongo Central prov.] Vista [Nsiamfumu], 6 Nov 1947, L. Toussaint 27 (BR0000017454599); Katanga prov., Mitwaba, Nov 1948, G.F. de Witte 4816 (K); [Tswhopo prov.] Basoko, Jun 1949, R. Germain 4959 (BR0000017455268); [Haut-Uele prov.] Uele, 3 Mar 1952, G. Troupin 282 (K, WAG0185123); [Kwango prov.] Popokabaka, 23 Sep 1952, H. Callens 3707 (BR0000017544780, WAG1103266); [Orientale prov.] Albert Lake, Semliki, 5 Mar 1954, D. van der Ben 1184 (BR0000017455664, K); [Sud Ubangi prov.] Zongo, 13 Jul 1957, C. Evrard 2561 (BR0000017455602); Coquille Territory, Indjolo, 3 Oct 1957, C. Evrard 2611 (BR0000017455237); [Haut-Katanga 


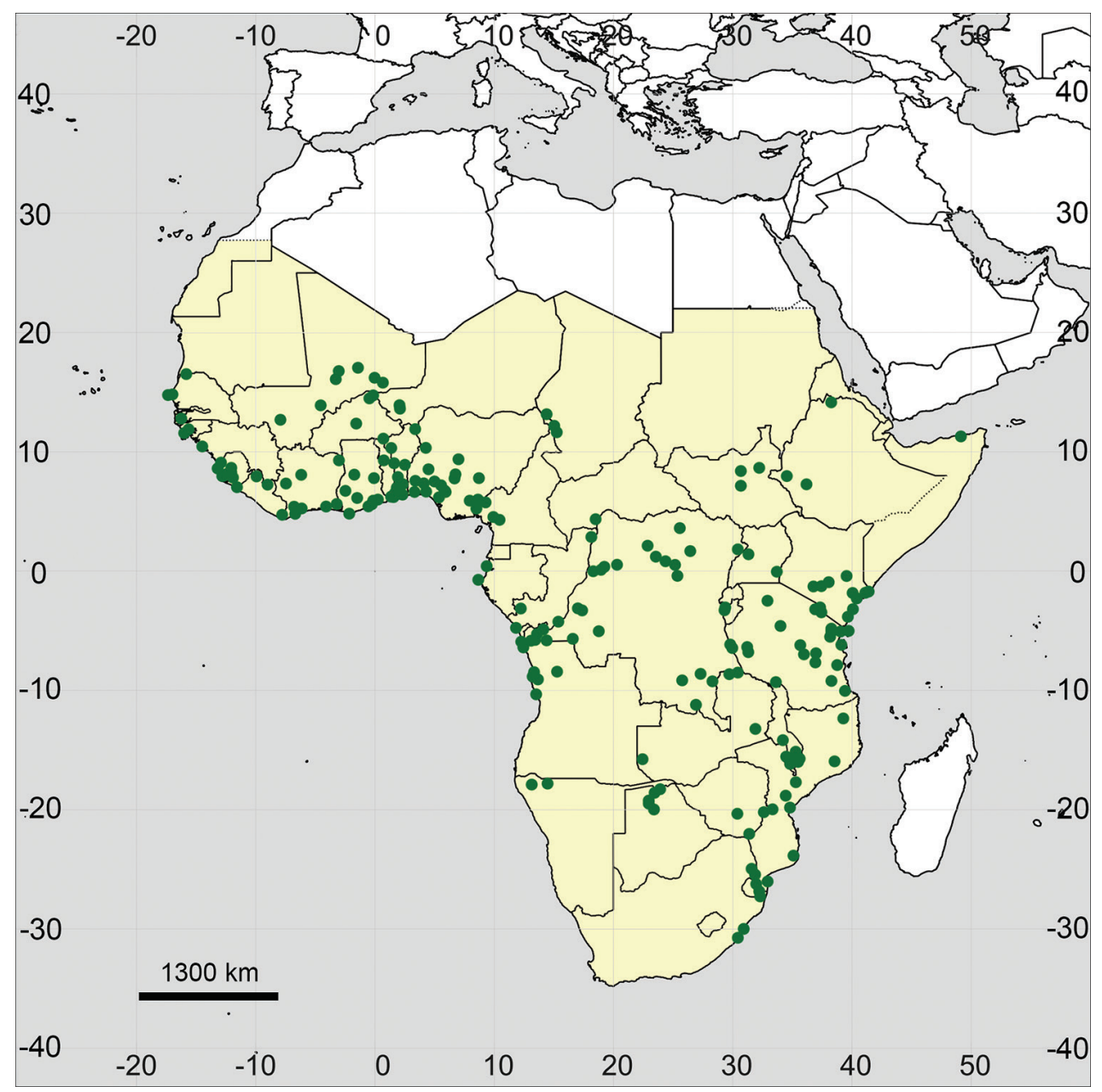

Figure 24. Distribution map of Glinus oppositifolius var. oppositifolius in Sub-Saharan Africa (colored in yellow).

prov.] Lupoto, 27 Nov 1957, A. Schmitz 6031 (BR0000017455763); [Sankuru prov.] [Province of Équateur] Bolomba, 3 Sep 1958, C. Evrard 4948 (BR0000017455251); [Tshopo prov.] Yangambi, 7 Sep 1959, P. Bamps 701 (BR0000017455169; WAG0185116); [Bas-Congo prov.] Seke-Banza, Isangila, 22 Sep 1959, P. Compere 438 (BR00000174554797); [Kongo Central prov.] Kasangulu, Ngombe, 16 Jul 1964, L. Pauwels 4590 (BR0000017454988); Katanga prov., Kilwa, 900 m a.s.l., 31 Dec 1965, J.-J. Symoens 11996 (K); [Haut-Lomami prov.] Lualaba river, Bukama, 2 Oct 1970, M. Lukuesa 740 (BR0000017455756; WAG0185117); Haut-Katanga prov., Kilwa, Moero Lake, 16 Oct 1970, S. Lisowski 61915 (BR0000017455725); [Tshopo prov.] Kisangani, 5 Nov 1977, J. Lejoly 2075 (BRLU0026269); [Tshopo prov.] Ubundu, 12 Jul 1981, Ndjele 427 (BRLU0026273); [Kongo Central prov.] Luozi, 28 Sep 1986, H. Breyne 5215 (BR0000017454759); [Kwilu prov.] Kikwit, 12 Aug 1991, B. Masens 
1013 (BR0000017455084, K, WAG0405337); [Tshopo prov.] Lokutu, 7 Nov 2004, Q. Luke et al. 106292 (K); Moenge, Itimbiri river, 360 m, 17 May 2010, Boyekoli Ebali Congo Exp. 501 (BR0000000571554);

Eтніорia: [Southern Nations, Nationalities and Peoples' region, Keffa zone] Gogeb river, Bonga road, 1300 m, 25 Feb 1966, W.J.J.O. de Wilde \& B.E.E. de WildeDuyffes 10194 (BR0000018270037, K, WAG1103268); [Oromia region] Illubabor zone, Alwero river, Abobo, 630 m, 20 Apr 1982, I. Friis \& al. 2475 (K);

Gabon: [Ogooué-Maritime prov.] Port Gentil, 12 Sep 1968, FJ. Breteler \& R.A. van Raalte 5526 (WAG0185127); N of Libreville, 13 Aug 1992, J. Dibata 1055 (WAG0070773);

Note. All other specimens identified as Glinus oppositifolius indeed belong to $G$. hirtus, Gisekia pharnaceoides (Gisekiaceae) and Polycarpaea sp. (Caryophyllaceae).

Ghana: Volta river, 27 Mar 1922, J.M. Dalziel 106 (K, M); [nr Accra] Pokuase, Apr 1931, F.R. Irvine 1589 (E, K); [Ashanti region] Fumso, 24 Mar 1950, Anonymous 543 (K); [Western region] Princes Town, 11 Mar 1952, J.K. Morton 6607(K, WAG1 103299); [Oti region] Kete-Krachi, 19 May 1952, J.K. Morton 7288 (K); [Greater Accra region] between Weija and Senya Bereku, 20 Mar 1954, J.K. Morton 204 (WAG0185093); [Eastern region] Mamfe, 6 Apr 1955, J.K. Morton 320 (K); [Brong-Ahafo region] Jema, 30 Oct 1955, C.D. Adams 3328 (K); [Greater Accra region] Nungua, 26 Mar 1956, J.O. Ankrah 20166 (K, M, P04577153, W); [Greater Accra region] Nungua, 25 May 1960, R. Rose-Innes 31247 (P04577159); [Greater Accra region] Achimota, May 1961, F.R. Irvine 5474 (K); [Ashanti region] $75 \mathrm{~km} \mathrm{~W}$ of Kumasi, Tano river, 24 Dec 1963, R.A.A. Oldeman 825 (B101143638, BR0000018269888, K, P04577254, WAG0185089); Brong-Ahafo region, between Nkoranza and Kintampo, 27 Dec 1995, C.C.H. Jongkind \& C.M.J. Nieuwenhuis 2548 (BR0000018269871, WAG0050916);

GuineA: [Boke region] Monchon, 6 Feb 1979, S. Lisowski 51384 (BR0000018269802);

Guinea-Bissau: Antula, 21 Mar 1943, Anonymous 1499 (B101143640, BR0000018269819, FT0007105, K, M, P04577132, WAG0104159); [Bissagos Islands] Formosa, 26 Apr 1945, Anonymous 1969 (B101143639, K, M);

Ivory Coast: [San Pédro region] San Pédro, 1900, M. Thoiré 123 (P04577229); [Woroba distr.] Mankono, 2 Jul 1909, A. Chevalier 22002 (P04577125); [Bas-Sassandra distr.] $49 \mathrm{~km} \mathrm{~N}$ of Sassandra, nr Dakpadou, 25 Feb 1959, A.J.M. Leeuwenberg 2858 (BR0000018269864, FT0007110, E, K, M, P04577188, U1398743, WAG0176054); [Montagnes distr.] nr Troya, Cavally river, 8 Mar 1962, J.J.F.E. de Wilde \& A.J.M. Leeuwenberg 3555 (BR0000018269857, K, WAG0185084); [Comoé distr.] Ayamé, 12 May 1965, L. Aké Assi 8060 (G); [Lacs distr.] Andokoi, 18 Jul 1970, L. Aké Assi 11277 (G); [Lacs dept.] Betrikan stream, 24 Mar 1971, J. Audru 3828 (P04577264); Bas-Sassandra distr., Niénokoué, Feb 1983, N. Stäuble 0861 (G423540); Bas-Sassandra distr., nr Louga, 8 Apr 1973, J. de Koning 1269 (BR0000018269840); [Zanzan distr.] Bouna, 1 May 1989, P. Poilecot 3923 (G);

Kenya: [Lamu county] Witu, Dec 1892, J.W. Gregory s.n. (BM); Sokoke, 14 Apr 1945, G. W. Jeffrey 162 (G); [Mombasa county] Kibarani, 4 Apr 1946, G.M. Jeffrey 515 
(K); Kilifi county, 13 Feb 1946, G. W. Jeffrey 466 (G, K); Machakos county, Kiamkere, 25 Nov 1951, Kirrika 154 (B101143637, BR0000018270044, K); [Lamu county] Mukunguyu Lake, 5 Nov 1957, P.J. Greenway \& S.P. Rawlins 9449 (FT0007109, K); [Lamu county] Kiunga, 55 m NE Lamu, 6 Aug 1961, J.B. Gillespie 167 (K001394829); Garissa county, $26 \mathrm{~km}$ from Garissa on Hagadera Rd, $0^{\circ} 16^{\prime} \mathrm{S}, 39^{\circ} 47^{\prime} \mathrm{E},-230 \mathrm{~m}$, 29 May 1977, J.B. Gillett 21195 (K); Rare river, 11 Dec 1979, J.M. Reitsma 413 (BR0000018268782, WAG0318591); Lamu county, Badar Water Pan, 5 Mar 1980, M.G. Gilbert \& P. Kuchar 5892 (K); [Coast prov.] Lamu county, Ras Tenewi, 19 Nov 1988, P. Luke \& S.A. Robertson 1425 (K); Kilifi county, Mangea Hill, 250 m, 27 Dec 1988, P. Luke 1587 (K); Tana River county, Tana River Primate Reserve, 17 Mar 1990, P. Luke et al. 524 (K); [Kitui county] Mwingi, 23 Jun 2005, P. Kirika et al. 542 (K); Lamu county, Bodhei to Basuba, 26 Jul 2006, L. Festo et al. 2649 (K); [Kilifi county] Malindi, 17 Nov 2010, S.A. Robertson 7871 (K);

Liberia: [Lofa county] Jenneh, 7 Apr 1909, M. Dinklage 2558 (B101143641); [Nimba county] Ganta, 5 Jun 1973, A. Jacques-Georges 27822 (BR0000018269833, M, WAG0185083); Maryland county, Cavally river, 8 Apr 2000, C.C.H. Jongkind \& J. Assi-Yapo 4991 (WAG0013107);

Malawi: [Southern region] Chikwawa distr., Lower Mwanza River, 180 m, 3 Oct 1946, L.J. Brass 17931 (K); [Southern region] Chikwawa distr., Lengwe NP, $300 \mathrm{ft}$, 15 Dec 1970, A.G. Hall-Martin 1168 (K, P04577250); [Central region] Dedza Distr., Chipoka, 15 Mar 1972, A.J. Salubeni 1785 (K); [Southern region] Machinga Distr., Lake Chiuta Harbour, 23 Dec 1984, I.H. Patel \& W. Nachamba 1764 (K); [Southern region] Machinga distr., Dinji vill., 8 Jun 1988, A.J.Salubeni \& I.H. Patel 5203 (K); [Southern region] Zomba distr., Chilwa Lake, Mchisi island, 7 Nov 1986, A.J. Salubeni \& R.B. Kwatha 4814 (K); Southern Region, Mpoto lagoon, Mauzi, Phalombe, 15³9'23"S, 3549'9"E, 638 m, 7 Dec 2013, H.T. Vhapama et al. 1088 (K);

Malı: Gao Region, Bamba [without date], exherb. A. Chevalier 42330(P04577220); [Niger Delta region] Djenné, 29 Jun 1899, A. Chevalier 1193 (P04577226); [Timbuktu Region] Timbuktu, 8 Aug 1927, O. Hagerup 247 (BR0000017461023, K); [Timbuktu region] Saré-Yamou, 8 May 1932, ex herb. A. Chevalier 183 (P04577221); Gao region, Bagoundjé, 5 Jul 1936, M. de Wailly 5079 (P04577225); Gao region, Niger river, 6 Sep 1936, M. de Wailly 5187 (P04577204); nr Bamako, Sotuba, 13 Oct 1989, A. Raynal-Roques 22802 (P04577269);

Mauritania: [Trarza Region] Rosso, 11 Oct 1969, FN. Hepper 3617 (K, M);

Mozambique: Lorenço Marques [Maputo], Sep 1913, G. Borle 216 (K); Cabo Delgado prov., 12 Sep 1948, Barbosa 2097 (K); [Inhambane prov.] Homoine distr., 8 Sep 1948, M. Myre \& M.F. de Carvalho 232 (K); Manica prov., Dombe, 28 Oct 1953, J. Pedro 4493 (K); [Sofala prov.] Beira, 10 Sep 1962, A.R.A. Noel 2487 (K); Sofala prov., Gorongosa NP, 3 Feb 1963, A.R. Torre \& J. Paiva 9007 (BR0000017455930, M); Inhaca island, 23 miles E of Lorenzo Marques [Maputo], 200 m, 9 Sep 1964, A.O.D. Mogg 32038 (K); Lorenço Marques [Maputo] prov., Matola, 21 Jul 1965, A. Marques 588 (WAG1103275); Zambezia prov., Shire river, Vila Bocage, 13 Dec 1971, G. Pope \& T. Müller 598 (K); Maputo, 10 Oct 1980, P.A. Schäfer 7280 (BR0000017454452, 
WAG0155677); Zambezia prov., Mamala, 20 Dec 1996, A.R. Torre \& M.F. Correia 16648 (BR0000017454469);

Namibia: [Kunene region] Ongonga, 14 Jan 1904, A. Kestilä 30 (H1056354); [Omusati region] Ruacana Falls, 29 Apr 1962, T.T.Kotze 46 (K, M, PRE0823929);

Niger: Niamey, Sep 1957, A. Vaillant 891 (K); 100 km N of Niamey, Niger river, 14 May 1968, C. Geerling \& J. Bokdam 2681 (WAG0104161); Niamey, 2 Apr 1987, N. Leman 81 (BR0000018269963);

Nigeria: Lagos, 26 Mar 1896, Miller 72 (K); [Cross River State] Oban, 1912, P.A. Talbot s.n. (BM); [Benue State] Abinsi, 1912, J.M.Dalziel s.n. (BM); [River State] Port Harcourt, Jun 1930, T.D. Maitland s.n. (K); [Edo State] Benin, 1934, W.A. Fairbairn s.n. (BM); Ondo State, Owo, 31 Mar 1943, A.P.D. Jones 3087 (K); [Ogun State] Shasha (Omo) forest reserve, Akila, 30 Jan 1947, C.F. Onochie \& V. Emumwen 20687 (K); [Edo State] r[iver] Osse, Iguoriakhi ferry, 29 Jan 1948, J.P.M. Brenan 8925 (K); [Edo State], Okomu Forest Reserve, 27 Feb 1948, J.P.M. Brenan 9169 (K); [Ouo State] nr Ibadan, 12 Mar 1950, R.D. Meikle 1261 (K, P04577150); [Lagos State] Ikeja, 30 Dec 1952, C.F.A. Onochie 26671 (K); [Oyo State] nr Eruwa, 22 Apr 1958, D.J. Hamber 430 (K, P04577151); [Cross River State] Ebom, 28 Jun 1955, R.H. Stone 26 (K); [Oyo State] Gambari Forest Res., SW of Ibadan, 16 Jan 1958, de Wit 770 (WAG0185105); [Kogi State] Lokoja, 5 Jun 1958, B.O. Daramola 36930 (K, WAG0185106); [Niger State] Shagunu, $10 \mathrm{~km} \mathrm{~N}$ of Bussa, 31 Jul 1965, C.D.K. Cook 471 (K, P05307013); [Kogi State], Koton Karfe, 27 Feb 1968, B.O. Daramola \& A. Binuyo 61909 (K); Cross River State, Afunatam, 30 Mar 1972, J. Lowe 13580 (K); [Cross River State] Ikom, Agbokim waterfalls, 26 Feb 1973, Latilo \& Oguntaya 67685 (K. WAG0185111); [Ekiti State], Igbara Odo, Oruwo stream, 9 Mar 1973, Olorunfemi \& Fagbemi 70748 (K, WAG0185110); [Niger State] Minna, Gurara Waterfalls, 17 May 1973, Eimunjeze et al. 66411 (WAG0185108); Oyo State, Ibadan, Asejire, 4 May 1974, Z.O. Gbile 73431 (K, WAG0185112); [Edo State], Iguoriakhi, 16 May 1974, Eimunjeze \& Oguntayo 70213 (K);

Republic of Congo: Niari dept., 29 Nov 1951, J. Koechlin 1587 (P04576681); Ubangi river, 20 Feb 1963, de Nere 907 (P04577259); Moutou ya N'Gombé, 12 May 1968, P. Sita 2036 (P04577256); [Pool Malebo] Mbamu, 14 Oct 1969, F. Hallé 1641 (P04577257); nr Brazzaville, 26 Aug 1969, Y. Attims 205 (WAG0034944); nr Brazzaville, 15 Apr 1970, Y. Attims 442 (BR0000018270020); Kouilou Dept., 20 km SE of Pointe-Noire, Cayo Lake, 22 Mar 2017, E. Bidault \& al. 3022 (BRLU0018798);

Senegal (selected): "Waalo", 1831, Perrottets.n. (G); Dakar, 9 Apr 1948, J.G. Adam 1053(WAG1 103302); [Thiès region] Thiès, May 1948, R.P. Berhaut 924 (P04577233); [Dakar region] Mbao, 1950-1951, R.P. Berhaut 2020 (BR0000018269703, P04577235); [Dakar region] Dagoudane-Pikine, 23 Apr 1960, J. Raynal \& A. Raynal 5726 (P04577242); [Thiès region] Kayer, 16 Jun 1961, J. Raynal \& A. Raynal 7067 (P004577267); [Ziguinchor region] Bignona, 31 Mar 1964, R.P. Berhaut 7267 (BR7000577);

Sierra-Leone: [Northern prov.] nr Madina, 11 Apr 1892, G.F. Scott Elliot 5561 (BM, K); [Northern prov.] Mokele, Sep 1914, Anonymous s.n. (BM); [Southern prov.] 
Juring, 1 Dec 1926, F.C. Deighton 297 (K); [Northern prov.] Makump, 3 May 1929, F.C. Deighton 1707 (BM, K); [Southern prov.] Baoma, 16 Apr 1936, F.C. Deighton 3166 (K); [Northern prov.] nr Kasanko, 13 May 1951, P. Adams 225 (K); [Southern prov.] Ngokuma (Kori), 22 Jun 1952, F.C. Deighton 5845 (K); [Northern prov.] nr Kambia, Magbema, 25 May 1954, H.D. Jordan 958 (K); [Western Area prov.] Fogbo, 3 Mar 1964, Morton \& Jarr 917 (WAG0185090);

Somalia: [Puntland State] Ganaane to Marro Mogale Umberto I, Mar 1893, D. Riva 731 (FT0007112) [Note. This specimen was collected in the same locality as FT0007113 (var. lanatus)];

South Africa: [KwaZulu-Natal prov.] [Port of] Natal [Durban], 1847, Guienzius 138 (S, G, sub Mollugo serrulata Sond.); [KwaZulu-Natal prov.] Isipingo, 22 Jun 1893, B. Schlechter 2804 (BOL217408, FR-0132687, G, P04577164); Durban, 19 Oct 1894, M. Wood s.n. (P04577180); [KwaZulu-Natal prov.] Maputaland, Jun 1914, Anonymous 14294 (BOL217409); [KwaZulu-Natal prov.] Umbilo, nr Durban, 4 Dec 1919, C.E.Moss 6657 (K); [KwaZulu-Natal prov.] Port Shepstone, 9 Aug 1919, R.G.Strey 6444 (BR0000017454520, K, M); [KwaZulu-Natal prov.] Durban, 20 Sep 1965, C.J. Ward 5148 (K); [KwaZulu-Natal prov.] Ndumo Game Reserve, 9 Jan 1969, E.S. Pooley 364 (E); Kruger NP, [Mpumalanga prov.] Crocodile river, nr Komatipoort, 7 Apr 1992, van Rooyen \& Bredenkamp 518 (PRE0784699); [Mpumalanga prov.] Kruger NP, Skukuza, 5 Jan 2006, F. Siebert \& S.J. Siebert 146 (PRE0851635);

South Sudan: [Sudd region] Bahr el Zeraf, 26 Apr 1930, N.D.Simpson 7790 (BM, K); [Upper Nile State] [Upper Nile State] Sobat river, nr Nyanding, 7 Jun 1929, D. Simpson 7085 (BM, K); [Upper Nile State] Shambe, 14 Jul 1929, D. Simpson 7380 (BM, K);

SwaZiland: Blue Jay Ranch, Lubombo Mountains, 30 Oct 1977, J.Culverwell 1114 (K, PRE0498323);

Tanzania: Zanzibar, 1847, L.H. Boivin s.n. (P04577175); Zanzibar, Jul 1873, J.M. Hildebrandt 907 (BM, LE); Kilimanjaro region, [Moshi Rural distr.] Kahe, Apr 1895, G. Volkens 2188 (E, LE); Pemba [island], [without date] J.H. Vaughan 899 (K); [Lindi region] Masoko, 4 Nov 1912, A. Stolz 1649 (K); [Mbeya region] Kyimbila, N of Lake Nyasa, 1915, A. Stolz K13 (BM, BOL21741 1, BR0000017454384, K); Tanganyika terr., [Pwani region] Rufiji, 3 Jan 1931, Anonymous 168 (K); Tanga region, Amboni, 6 Jul 1932, Geilinger 661 (K); [Lindi region] $40 \mathrm{~km} \mathrm{~W}$ of Lindi, Lutamba Lake, 29 Nov 1934, H.J. Schlieben 5660 (B101143615, BM, BR0000017454377, G); [Katavi region] Lake Katavi, 3500 ft, 25 Jan 1950, A.A. Bullock 2334 (K); [Mwanza region] $3700 \mathrm{ft}, 24$ Oct 1952, R.E.S. Tanner 1100 (BR0000017454322, FT0007111, E, K, WAG1103308); [Tanga region] Mkomazi river, 2 miles NE of Lake Manka, 440 m, 1 May 1953, R.B. Drummond \& J.H. Hemsley 2347 (B101143612, BR0000017454391, FT0007106, K); Tanga region, Pangani, $500 \mathrm{ft}$, 23 Jul 1955, R. Tanner 1982 (K); Tanga region, Pangani, 27 Nov 1955, R. Tanner 2369 (BR0000017454339, K); [Pwani region] Utete by river Rufiji, 120 m, 2 Dec 1955, E. Milne-Redhead \& P. Taylor 7527 (B101143610, BR0000017454360, K); [Morogoro region] Ilonga, Kilosa, 1700 ft, 18 Jan 1958, M. Cole 58 (K); [Kigoma 
region] Lake Tanganyika, Kibwesa point, 6³0'S, 2957'E, 3000 ft, 20 Aug 1958, T.G. Jefford \& J. Newbould 1673 (K); [Kigoma region] Kungwe Mt, Kasoje, $2600 \mathrm{ft}$, 17 Jul 1959, J. Newbould R.M. Harley 4408 (B101143609, BR0000017454315, K); [Tanga region] Nzega distr., Wembere escarpment, 1200 m, 31 Oct 1960, H.M. Richards 13452 (K); [Morogoro region] Kilosa distr., Mazunyungu river, 25 Nov 1961, S.R. Samsei 3443 (K); Dodoma region, 1 mile S of Dodoma, Imagi hill, 4000 ft, 29 Jan 1962, R. Polbill \& S. Paulo 1290 (B101143611, BR0000017454292, K, P04577203); [Dodoma region] Mtera, 19 Apr 1962, R. Polbill \& S. Paulo 2077 (B101143604, BR0000018268904, K); Zanzibar, Migombani, 18 Aug 1962, Faulkner 3090 (BR0000018269062, K); [Tanga region] Lushoto, Korogwe stream, 15 Dec 1962, M.E. Archbold 83 (K); Arusha region, Ngurdoto NP, 1650 m, 13 Apr 1965, M. Richards 20178 (BR0000018270082, K); [Arusha region] Longil Lake, Ngurdoto Crater NP, 4900 ft, 24 Feb 1966, P.J. Greenway \& Kanuri 12385 (BR0000017454278, K); Arusha NP, Lake Kawanya ya Matteo, 1524 m, 4 Nov 1969, H.M. Richards 24592 (BR0000018270089, K); Arusha region, Lekuruki vill., 914 m, 5 Dec 1969, H.M. Richards s.n. (BR0000018270136, K); [Morogoro region] Kilosa, at Ruaha river within $1 \mathrm{~km} \mathrm{E}$ of Kidatu bridge, $400 \mathrm{~m}, 17 \mathrm{Jul} 1970, M$. Thulin \& B. Mhoro 478 (K); [Katavi region] Kapapa, 974 m, 19 Sep 1970, H.M. Richards \& S. Arasululu 25994 (BR0000018270112, K); Arusha NP, Ngongongare Maji-ya-Punda gorge, 4900 ft, 1 Feb 1971, H.M. Richards \& S. Arasululu 26625 (BR0000018270129, K, M); [Morogoro region] Kidatu, 77'S, 369'E, 14 Jan 1971, B. Mhoro 178 (BR0000018270075, K); Arusha distr., Lekuruki area, 27 Mar 1971, H.M. Richards \& S. Arasululu 26866 (BR0000018270105, K); Iringa region, Ruaha NP, 790 m, 26 Jan 1972, A. Bjornstad 1274 (K); [Lindi region] nr Kingupira, 25 Jun 1975, K. Vollesen 2490 (WAG1103312); Tanga [region] Tanga, 1 Oct 1979, F.C. Magogo 2000 (BR0000017454261); Tanga region, 4 Sep 1987, M.E. Archbold 8145 (K); [Tanga region] Kwamkono, 20 Sep 1990, M.E. Archbold 3309 (K); Kilimanjaro, 7 Apr 1994, J.M. Grimshaw 94334 (K); [Tanga Region] Kwasunga, 23 Mar 2012, M. Alvarez 921 (B100599491);

Togo: Lomé, [years] 1900-1902, Warnecke 299 (BM, BR0000018269895, G, K, P04577158); Togo Lake, 29 Jan 1978, H. Scholz 2955 (B101143632, K, P04577245); Lomé, 15 Apr 1978, M. Hakki et al. 48 (B101143635, K); [Kara region] NW of Bassar, 25 Apr 1978, M. Hakki et al. 507 (B101143634, K, P04577246); Lomé, 17 Feb 1979, A.J.M. Leeuwenberg 11935 (BR0000018269918, WAG0185086); Aneho, $6^{\circ} 14^{\prime} \mathrm{N}, 1^{\circ} 37^{\prime} \mathrm{E}$, alt. $30 \mathrm{~m}, 26$ Jun 1985, Pasch 8626 (K); [Maritime region] Aného, 26 Jun 1985, P. Schäfer 8626 (B101143633, WAG0185087);

Uganda: Victoria Lake, Lolui Island, 11 May 1965, G. Jackson 511565 (K); [Western region] Masindi distr., Bunyoro, 1050 m, 15 Feb 1999, K.A. Lye \& A.B. Katende 23474 (K);

Zambia: [Western prov.] Kande Lake, 8 miles NE of Mongu, 11 Nov 1959, R.B. Drummond \& A.J.Cookson 6335 (E, K); [Muchinga prov.] [Northern prov.] Mweruwa-Ntipa, Katema island, 850'S, 2940'E, 2950 ft, 25 Jul 1962, P.J.Tyrer 109 (BM, BR0000017454421); [Northern prov.] Abercorn [Mbala] Distr., Sumbu Bay Lake, 
780 m, 29 Dec 1963, M. Richards 18710 (K); [Lusaka prov.] [Muchinga prov.] Mpika Distr., Mfuwe Camp, 2000 ft, 12 Dec 1968, W.L.Astle 5389 (K); [Northern prov.] Kaputa distr., Mweru Wantipa NP, 1000 m, 8 Dec 1993, M. Marello et al. 989 (WAG0023616);

Zimbabwe: [Masvingo prov.] Chivi, Lundi river, $2500 \mathrm{ft}, 30$ Oct 1955, H. Wild 4692 (BR0000017454445, K); [Manicaland prov.] Chipinge, S of Giriwayo camp, $1230 \mathrm{ft}, 13$ Mar 1957, J.B. Phipps 616 (K).

General distribution of the type variety. Tropics of the Old World. Additionally, we report here the first record from North Africa [Egypt: [Sinai Peninsula] Wadi Isleh, Jan 1903, R. Muschler s.n. (G!)].

\section{Glinus oppositifolius var. keenanii (C.B.Clarke) Sukhor., comb. nov.} urn:lsid:ipni.org:names:77215159-1

三Mollugo hirta var. keenanii C.B.Clarke, Fl. Brit. India 2: 662 (1879). Holotype: India.

[State of Assam], Cachar [District], Mar 1873, R.L. Keenan s.n. (K000641798!). = Mollugo herniarioides Gagnep., Notul. Syst. (Paris) 3: 367 (1918).

三 Glinus herniarioides (Gagnep.) Tardieu, Fl. Cambodge, Laos \& Vietnam 5: 97 (1967).

Lectotype (designated here): [Vietnam] Laisses de la rivière Noire à Tu-Phap, 8

Mar 1888, B. Balansa 3397 (P04601311!).

= Wycliffea rotundifolia Ewart \& A.H.K.Petrie, Proc. Roy. Soc. Victoria, n.s. 38: 169

(1926). Type: Australia. Northern Territory, Wycliffe, Jun 1924, A.J. Ewart s.n.

(MEL723997, image seen!).

= Glinus oppositifolius var. lanatus Hauman, Bull. Jard. Bot. État Bruxelles 19: 446

(1949). Holotype: Congo Belge [DR Congo], Boma, potte lieu inculte sabloneux humide, 1 Aug 1913, Bequaert 536 (BR000000895538!).

= Glinus microphyllus Hauman, Bull. Jard. Bot. État Bruxelles 19: 445 (1949). Holo-

type: [DR Congo]. Mateba, 14 Dec 1912, R. Verschueren 203 (BR000000895505!).

Habitat. Dry river beds and other water bodies, or as a weed.

Note. A variety with \pm villose pubescent stems, shorter leaves (up to $10 \mathrm{~mm}$ ) and shorter (up to $5 \mathrm{~mm}$ ) pedicels (Fig. 25). Some individuals also have shorter perianths $(2.7-3.6 \mathrm{~mm})$ and anthers $(0.3-0.6 \mathrm{~mm})$ as well as brighter (yellow-brown) seeds compared to the type variety, but these characters are not always diagnostic.

This interpretation and circumscription of the variety is undertaken for the first time. In Africa, plants known as G. microphyllus Hauman were considered endemic to DR Congo (Hauman 1949; Lebrun and Stork 2003). Phuphathanaphong (2005) reported G. oppositifolius var. keenanii (as G. herniarioides) from Thailand, but described it as stellate-pubescent. However, the type specimens have simple hairs only, and it is not clear which name should be applied to the Asian plant reported as "G. herniarioides".

Gagnepain (1918) cited two specimens from Vietnam collected by B. Balansa (no. $3397 \& 4613$ ). We found only duplicates numbered 4613 (Environs de Hanoi, dans les rizières après la moisson, June 1891, B. Balansa 4613), which were distributed from 
Paris to various herbaria (K000641793!, K! [without a barcode], E!, NY00288837, US00103110), whereas another gathering (Balansa 3397) was traced at P and is designated as lectotype here.

Ewart and Petrie (1926) reported that both Wycliffea obovata (=Glinus oppositifolius s.str.) and W. rotundifolia (= G. oppositifolius var. keenanii) were described from the same locality in Australia. The specimens collected by D. Riva in Somalia [Ganaane to Marro Mogale Umberto I, Mar 1893] also belong to different varieties: the specimen FT0007113 is a typical var. keenanii, while FT0007112 represents var. oppositifolius. Such plants with shorter leaves and pedicels are found in various localities across the distribution area of G. oppositifolius: in Australia, India, Vietnam, many African countries (Gilbert 2000; Fig. 26 in the present article). A specimen of G. oppositifolius var. keenanii used in the molecular study falls within G. oppositifolius subclade (Figs 1,2). We prefer to consider such plants as a variety of $G$. oppositifolius, perhaps growing under less favorable drier conditions.

Distribution (Fig. 26). Angola: Namibe prov., Tombe [Tombua], 15 Jan 1956, E.J. Mendes 1301 (LISC032017);

Benin: [Alibori dept.] Malanville, 26 Apr 1999, P. Houngnon et al. 6501 (BR0000017456159, WAG0235844);

Cameroon: North prov., Bénoué, 22 May 1974, C. Geerling \& J. Néné 4858 (BR0000017456128, WAG0330419);

DR Congo: see the type specimens of G. microphyllus and G. oppositifolius var. lanatus;

Eтнiopia: [Oromia region] Illubabor zone], $S$ of Abobo, 650 m, 14 Apr 1982, I. Friis et al. $2456(\mathrm{~K})$;

Kenya: Kwale county, 31 Aug 1953, R.B. Drummond \& J.H. Hemsley 4068 (BR0000018268805, FT0007108, K);

Malawi: [Southern Region] Shire Highlands, Jul 1885, J. Buchanan s.n. (E, K); [Southern region] Njobru, Mulanje, 17 Nov 1955, G. Jackson 1765 (BR0000018269130, K);

Mozambique: Gaza prov., Baxo Limpopo, 27 Aug 1969, M.F. Correia \& A. Marques 1280 (WAG1103322); [Sofala prov.] Beira, Jul 1970, K.L. Tinley 1936 (K, M); Inhambane prov., Vilankulos, 18 Sep 1973, M.F. Correia \& A. Marques 9417 (WAG1103327); Cabo Delgado [prov.], Ruvuma riverbank, 10³4'39"S, 40²1'11"E, 10 m, 15 Nov 2009, Q. Luke 13803 (K);

Somalia: [Puntland State] Ganaane to Marro Mogale Umberto I, Mar 1893, D. Riva 721 (FT0007113).

Sudan: [State of Sennar] Sennar, May 1867, A. Figari s.n. (FI059439);

Tanzania (new records): Morogoro Region, Magogoni, Aug 1930, A. Haarer 1839 (K); Rukwa Region, Rukwa, 2800 ft, 5 Dec 1954, H.M. Richards 3530 (K); [Tanga Region] Handeni distr., Horogwe to Handeni, 18 Nov 1955, E. Milne-Redhead \& P. Taylor 7337 (BR0000018269048, K); Rufiji distr., 2 Dec 1955, E. Milne-Redhead \& P. Taylor 7526 \& 7528 (BR0000018269031, BR0000018269055, K); [Manyara region] Mbulu distr., Tarangire NP, 1066 m, 24 Nov 1969, M. Richards 24759 (BR000017456005; K); 


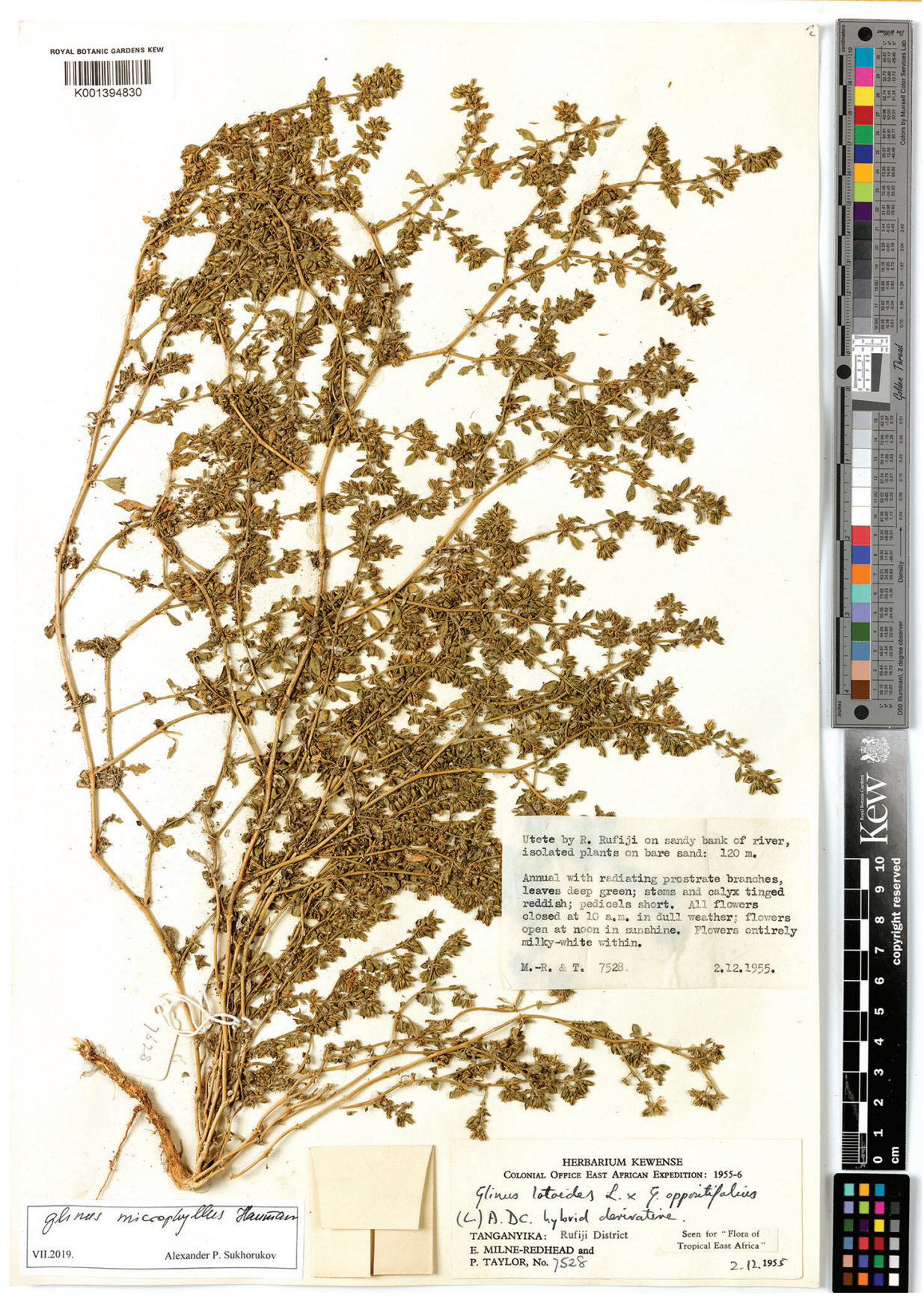

Figure 25. A herbarium specimen of Glinus oppositifolius var. keenanii labeled as G. microphyllus (Tanzania, Rufiji distr., 2 Dec 1955, E. Milne-Redhead \& P. Taylor 7528, K001394830). Copyright of the Board of Trustees of the Royal Botanic Gardens, Kew. 
Zambia: [Eastern prov.] Petauke distr., Luangwa river bridge, 5 Sep 1947, P.J.Greenway \& J.P.M.Brenan 8045 (K); Chinsali distr., Mbesuma, 11 Oct 1960, E.A. Robinson 3950 (K, M); Katondwe, 14 Nov 1963, D.B. Fanshawe 8129 (K); Luangwa valley, 4 Dec 1965, W.L. Astle 4166 (K); Western Province, Bulozi plain near Mongu, 1510'S, 2306'E, 1000 m, Oct 1993, M.G. Bingham 9743 (K, WAG0334359);

Zimbabwe: [Masvingo prov.] Nuanetsi, nr Malipati, 2 May 1961, R.B. Drummond \& R.O.B. Rutherford-Smith 7677 (K);

General distribution of the variety. Tropical Africa (incl. Madagascar: WAG!), Asia, Australia.

\section{Glinus oppositifolius var. glomeratus M.L.Gonçalves, Consp. Fl. Angol. 4: 317 (1970).}

Type. Angola. Pungo Andongo distr., [by a nearly dried swamp between Condo and Quisonde] 2400-3800 ft, [end of March 1857] F. Welwitsch 1111 (LISU, n.v.; isotypes BM!, BR!, K000221394!, K000221395!).

Note. The type label has been complemented with the information from Hiern (1898: 416).

Originally (Gonçalves 1965), the name G. oppositifolius var. glomeratus was invalidly published with a diagnosis in Latin based on two gatherings without explicit type designation. It was validated later (Gonçalves 1970) by indicating a "lectotype" and providing a full and direct reference to the validating diagnosis.

This variety is characterized by the clusters with $>10$ flowers, and sessile or shortly (up to $4.0 \mathrm{~mm}$ ) pedicellate flowers (Fig. 27). It may represent a montane variety of $G$. oppositifolius growing at higer altitudes (1000-2000 m), because one of the specimens cited by Gonçalves (1965) from Bié province, Angola, was collected at the elevation of $1360 \mathrm{~m}$ a.s.l. However, we did not include the samples of this variety into the molecular analysis, and further studies are needed to prove its varietal rank.

The plants of G. oppositifolius var. glomeratus look similar to G. hirtus. However, at least two characters distinguish it from the latter species: simple curved hairs vs. stellate pubescence, and shorter (0.3-0.6 mm long) stylodia (as in the type variety) vs. 0.5$1.0 \mathrm{~mm}$ long stylodia in $G$. hirtus. This variety was reported from Angola (Gonçalves 1970), but here we extend its distribution into DR Congo, Tanzania and Zambia.

Distribution (Fig. 26). Angola: [Cuanza Sul prov.] between Condo and Quisonde [Porto Amboim], Mar 1854, F. Welwitsch 1111 (BM); Cuando-Cubango prov., Longa, Longa river, 1360 m, 17 Mar 1960, E.J. Mendes 3155 (BM013839321, LISC032016, M);

DR Congo (new records): [Kongo Central prov.] Kisantu, Kingimba Kinga, 3 Oct 1958, L. Paulwels 108 (BR0000017454933); [Haut-Katanga prov.] 26 km NW of Lubumbashi, Lupoto, 2 Mar 1961, A. Schmitz 7129 (P05307011); Haut-Katanga prov., Kundelungu Plateau, 1700 m, 24-29 Mar 1969, S. Lisowski et al. 4053 (BR0000018268348);

Tanzania (new records): Shinyanga Region, Shinyanga, 1932, R.D. Bax 23 (K); 


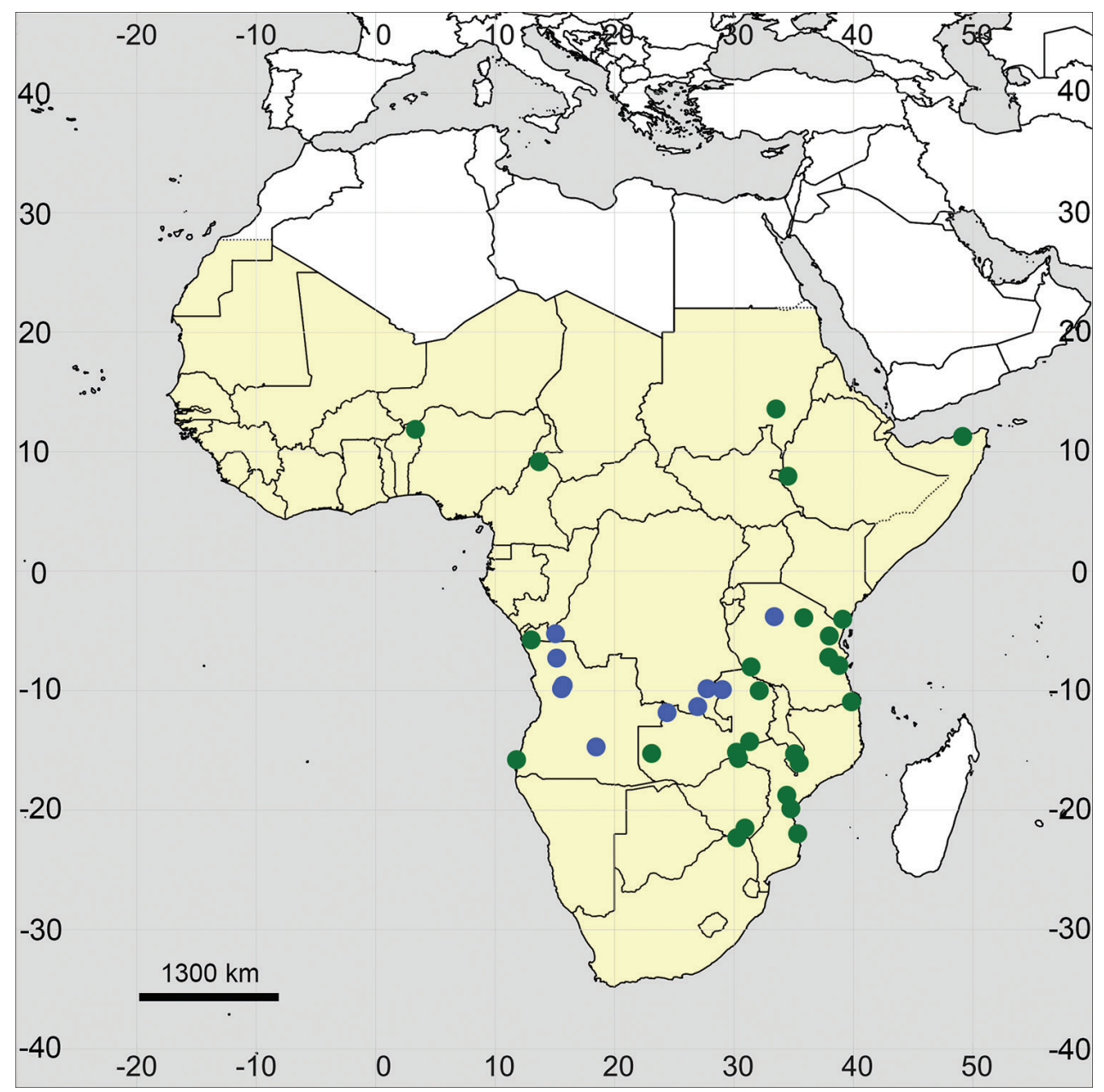

Figure 26. Distribution map of Glinus oppositifolius var. keenanii (green circles) and G. oppositifolius var. glomeratus (blue circles) in Sub-Saharan Africa (colored in yellow).

Zambia (new records): [Luapula prov.] Kawambwa, 23 Aug 1957, D.B. Fanshawe 3561 (K); [North-Western Province] Mwinilunga District, Mujileshi river, 1290 m, 8 Nov 1962, H.M. Richards 16953 (K).

General distribution of the variety. Tropical Africa (south of the equator).

Glinus setiflorus Forssk., Fl. Aegypt.-Arab.: 95 (1775).

三 Plenckia setiflora (Forssk.) Raf., Specch. 1: 194 (1814).

$\equiv$ Glinus lotoides var. setiflorus (Forssk.) Fenzl, Ann. Wiener Mus. Naturgesch. 1: 358 (1836). 
三 Mollugo setiflora (Forssk.) Chiov., Bull. Soc. Bot. Ital. 1923: 114 (1923). Lectotype (designated here): Yemen. Al Hudaydah Governorate. "Dahhi" [Ad Dahi distr.], [between Al-Luhayyah and Bayt Al Faqih, Feb 1763,] P. Forsskål Herb. Forsskål 542 (C10002326; isolectotypes BM000902703, C10002322, C10002323, C10002324, C10002325, S04-343).

Note. Jeffrey (1961: 16) indicated the "type" of Glinus setiflorus at C. He had not seen the material, and failed to distinguish between several sheets in Forsskål's collection. We designate one of these specimens as lectotype, which was seen and annotated by P.Ascherson in 1881.

The locality information and collection date are complemented from Hepper and Friis (1994).

Description. (Fig. 28). Annual with prostrate or ascending stems densely covered with persistent stellate hairs; prickles absent. Leaves shortly petiolate (petioles $2-15 \mathrm{~mm}$ long), grey or white, farinose, entire or slightly crisp, 10.0-35.0 $\times 7.0-25.0 \mathrm{~mm}$, obovate to almost roundish, veins adaxially recessed and abaxially prominent. Flowers in clusters of (1) $2-4$, sessile or with pedicels up to $5(10-15) \mathrm{mm}$ long. Perianth segments 5 , ovate, in flowering $6.0-7.0 \mathrm{~mm}$ long, in fruiting $9.0-11.0 \times 7.0-8.0 \mathrm{~mm}$, with a mucro $0.5-1.0 \mathrm{~mm}$ long; white or creamy inside, abaxially with dense stellate hairs; flower buds and anthocarp ovoid or almost roundish (Fig. 5A); yellowish multifid petaloids often present. Stamens 5; anthers 0.8-1.0 mm long. Stigmas 5, 0.7-1.2 mm (sometimes a style is present up to $0.7 \mathrm{~mm}$ long). Seeds $0.7-0.9 \times 0.50-0.60 \mathrm{~mm}$, almost black, colliculate and without longitudinal striae; aril hood often reduced, rarely clearly visible, and in the latter case up to $0.30 \mathrm{~mm}$ long.

Habitat. Sands, seasonally flooded depressions, rocks, limestones or clayey soils; $0-1300 \mathrm{~m}$.

\section{Distribution (Fig. 29).}

Ethiopia: [Oromia Region] Adama, 23 Dec 1913, D. Riva 1999 (FT0007119); [Somali region] Ogaden distr., Danot, 2 Dec 1944, P.E. Glover \& H.B. Gilliland 440 (BM, K); [Afar Region] Afambo, May 1953, E. Chedeville 13 (FT0007028 - right specimen); [Somali region] Ogaden, nr Mardere, 2 Dec 1953, G. Popov 1143 (K); [Somali region] Balbeh Danot, 30 Jun 1958, C.F.Hemming 1486 (FT0007118, K); [Somali region] N of Gara Afdem Mtn., 9 $38^{\prime} \mathrm{N}, 40^{\circ} 50^{\prime} \mathrm{E}, 20$ Jan 1964, W. Burger 3417 (FT0007116, K, WAG0185097);

Kenya: Ewaso Ng'iro river, 2 May 1945, P.R.O. Bally 4506 (K); [Isiolo county] Kipsing, 2 May 1945, P.R.O. Bally 4506 (G); [Mandera county] Banissa, 1020 m, 22 May 1952, J.B. Gillett 13257 (BR0000018268812, FT0007120, K); [Isiolo county] Tana River distr., nr Garba Tula, 18 Jul 1952, P.R.O. Bally 8224 (FT0007125, K); Garissa county, S of Garissa, 26 Sep 1957, P.J. Greenway 9236 (FT0007121, K); [Mombasa county] Mombasa, 30 Oct 1959, D. Napper 1343 (BR0000017456050, K); [Tana river county] Kamor Jila, 121'S, 39 ${ }^{\circ} 55^{\prime} \mathrm{E}, 12$ Dec 1964, J.B. Gillett 16414 (BR0000017456067, FT0007123, K, P04577112, WAG1103335); [Taita-Taveta county] Tsavo NP, 2 Jan 1967, P.J. Greenway \& Kanuri 12937 (FT0007122, K); Tur- 


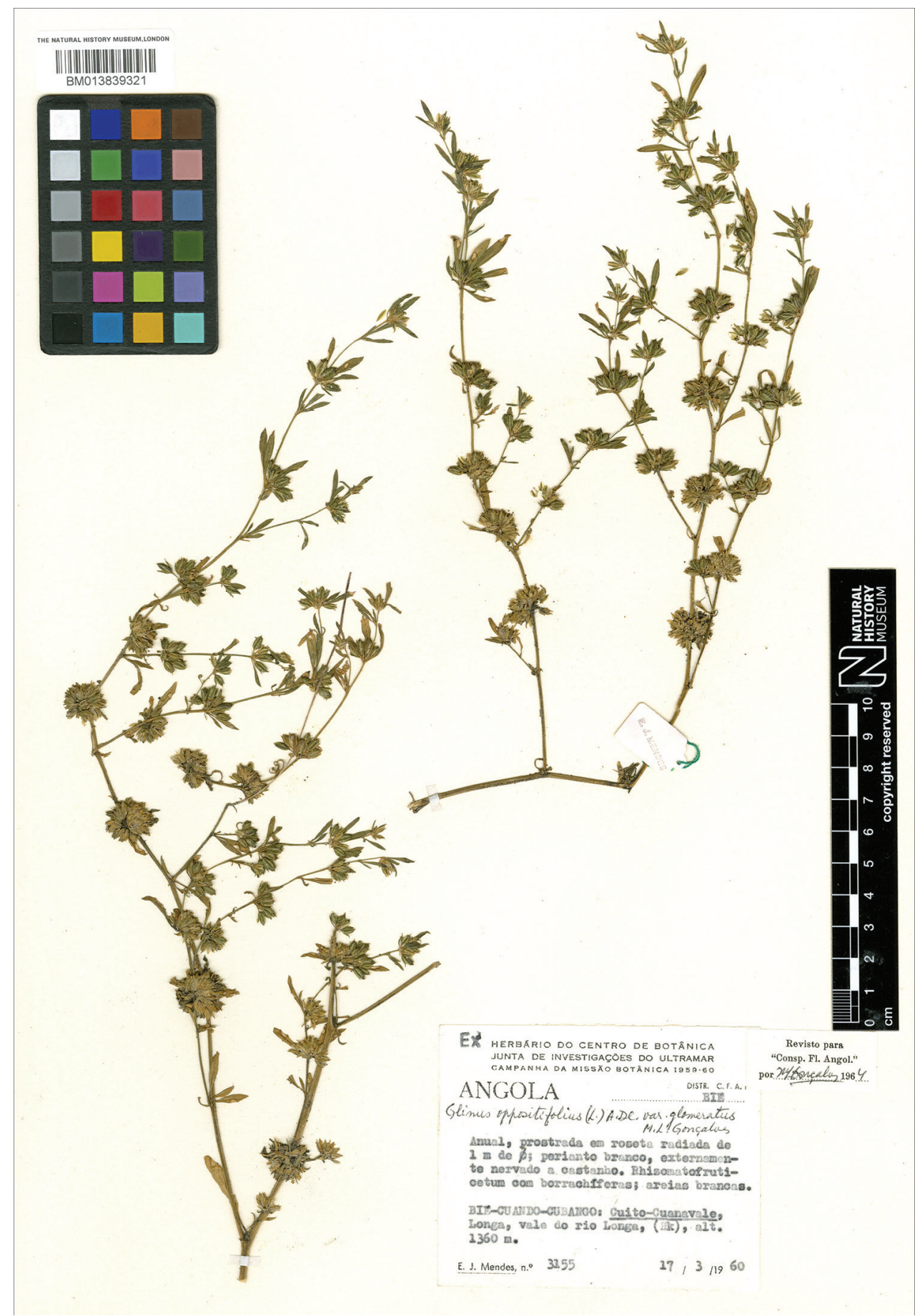

Figure 27. A herbarium specimen of Glinus oppositifolius var. glomeratus (Angola, Cuando-Cubango prov., Longa, Longa river, 1360 m, 17 Mar 1960, E.J. Mendes 3155, BM013839321). 
kana county, Lomesekin, locally very common, 29 Aug 1968, O.M. Mwangangi \& D. Gwynne 1218 (K); Turkana county, Lodete, 570 m, 24 Jul 1969, O.M. Mwangangi 1378 (FT0007124, K); [Mandera county] 54 km NE of El Wak, 380 m, 12 Dec 1971, Bally \& Smith 14572 (K); Samburu county, nr Wamba, 3 Jul 1974, R.B. Faden \& A.J. Faden 74-946 (BR0000017456043, K, WAG1103337); Garissa county, Garissa to Hagadera, 230 m, 29 May 1977, J.B. Gillett 21193 (FT0007126, K); [Tana River county] Kora camp junction, 3 Sep 1983, G.M. Mungai 83/35 (K); [Makueni county] Chyulu plains, Kigelia, 26 Jul 1992, Luke 3204 (K); [Kitui county] Ukasi Dam, 3 Aug 2006, L. Festo \& Q. Luke 2813 (K, LE); Makueni county, Kibwezi, 990 m, 22 Nov 2010, Q. Luke 14955 (K);

Somalia: [Sanaag region] nr Dofar [El Dahir], 19 Oct 1954, P.R.O. Balley 10115 (FT0007117, K); [Lower Juba Region] Lag Badana, 28 Oct 1971, G. Moggi \& $R$. Bavazzano s.n. (FT0007034); [Bay region] Dinsoor, 16 Feb 1981, J.J. Beckett 1491 (K); [Galguduud region] $27 \mathrm{~km} \mathrm{~S}$ of Guri Ceel, 50 $05^{\prime} \mathrm{N}, 45^{\circ} 47^{\prime} \mathrm{E}, 6$ Jun 1988, $P$. Kuchar 17836 (K);

Sudan: Kassala State, S of Tob el Ahmar, 16 Apr 1961, J.K. Jackson 4143 (K);

TAnzania: [Dodoma region] 29 miles $S$ of Dodoma, $3500 \mathrm{ft}, 15$ Aug 1928, P.G. Greenway 773 (BM, K); Dodoma region, Ikowa Dam, $60 \mathrm{~km}$ E of Dodoma, $900 \mathrm{~m}$, 29 Jul 1970, M. Thulin \& B. Mhoro 515 (K001394832); Dodoma county, Ikowa reservoir, 980 m, 19 Jun 1974, B. Mhoro \& I. Backéus 1949 (WAG0192068).

General distribution. East Africa; Arabian Peninsula (Yemen). In addition to the records cited, it is apparently present in Djibouti and Eritrea. In Yemen, where G. setiflorus was described from, it is only known from the type locality (Miller 1996).

\section{Glinus zambesiacus Sukhor., sp. nov.}

urn:Isid:ipni.org:names:77215160-1

Fig. 30

- Glinus lotoides $\times$ G. oppositifolius p.p., G. lotoides auct. non L., G. lotoides var. virens auct. non Fenzl; G. bainesii auct. non (Oliv.) Pax

Type material. Holotype: Zambia. Barotseland, [Western province] Mongu, mud at edge of river, 6 Jan 1966, Robinson 6780 (K000865904! iso - M!).

Description. Annual up to $70 \mathrm{~cm}$, often forming mats, with numerous prostrate or ascending stems, covered at least in young parts with dense stellate hairs, so that the plant appears greyish; prickles absent. Leaves in false whorls of 2-5, oblong-spatulate or obovate, rarely almost roundish, entire, 10.0-40.0(50.0) $\times 5.0-15.0(20.0) \mathrm{mm}$, shortly pedunculate (peduncles up to $15.0 \mathrm{~mm}$ ), green, scarcely pubescent, rarely subvillose, veins not prominent abaxially. Flowers in clusters of 2-12, pedicellate (pedicels 5.0-20.0 mm long, rarely shorter). Perianth cylindrical (Fig. 5B), perianth segments (5) oblong or ovate, $5.5-7.0 \mathrm{~mm}$ long at anthesis, $2.5-3.0 \mathrm{~mm}$ wide, abaxially with scattered stellate, easily caducous hairs (at least along mid-vein), abaxially green or pink 


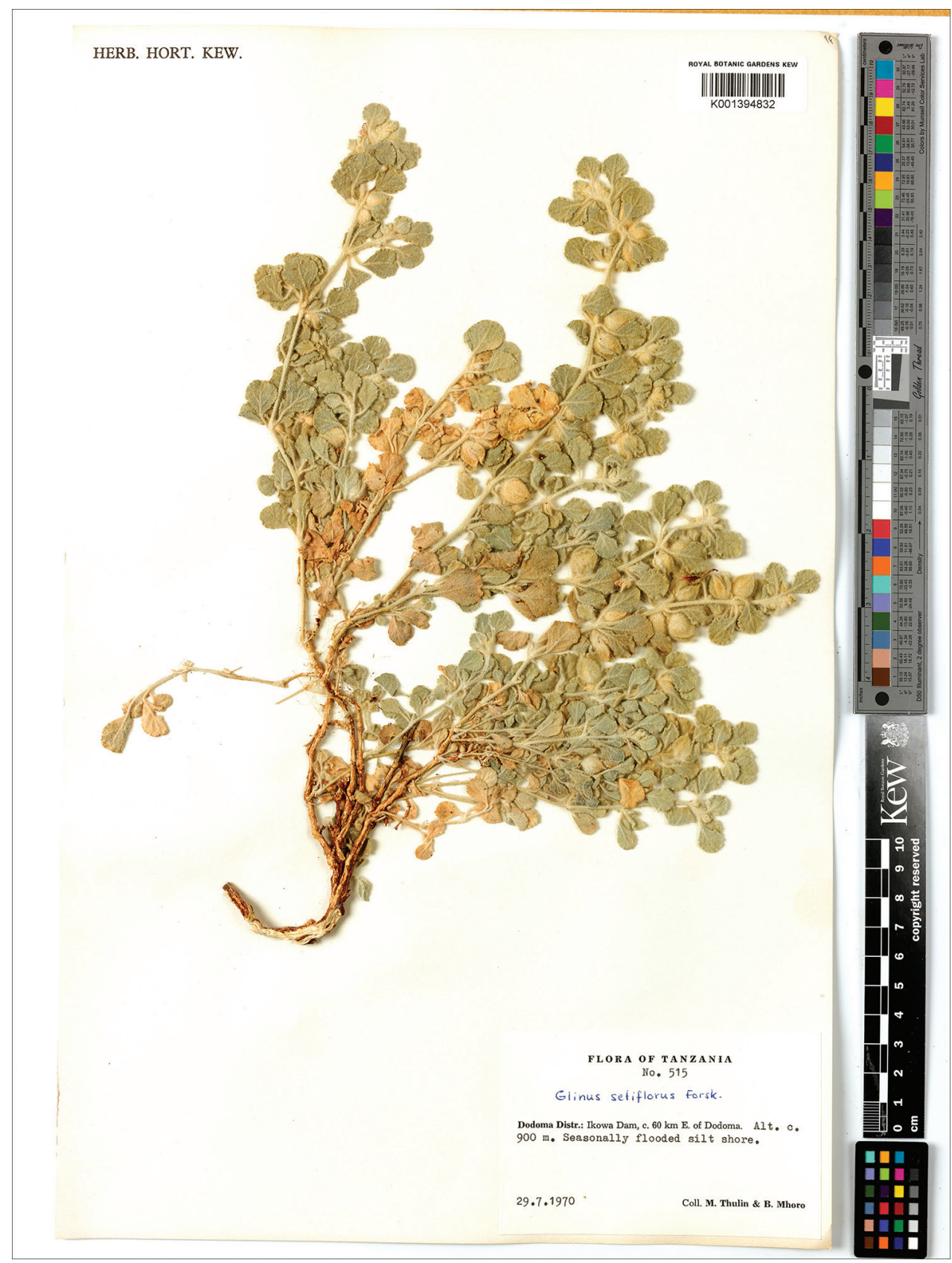

Figure 28. A herbarium specimen of Glinus setiflorus (Tanzania, Dodoma region, Ikowa Dam, $60 \mathrm{~km} \mathrm{E}$ of Dodoma, 900 m, 29 Jul 1970, M. Thulin \& B. Mhoro 515, K001394832). Copyright of the Board of Trustees of the Royal Botanic Gardens, Kew. 


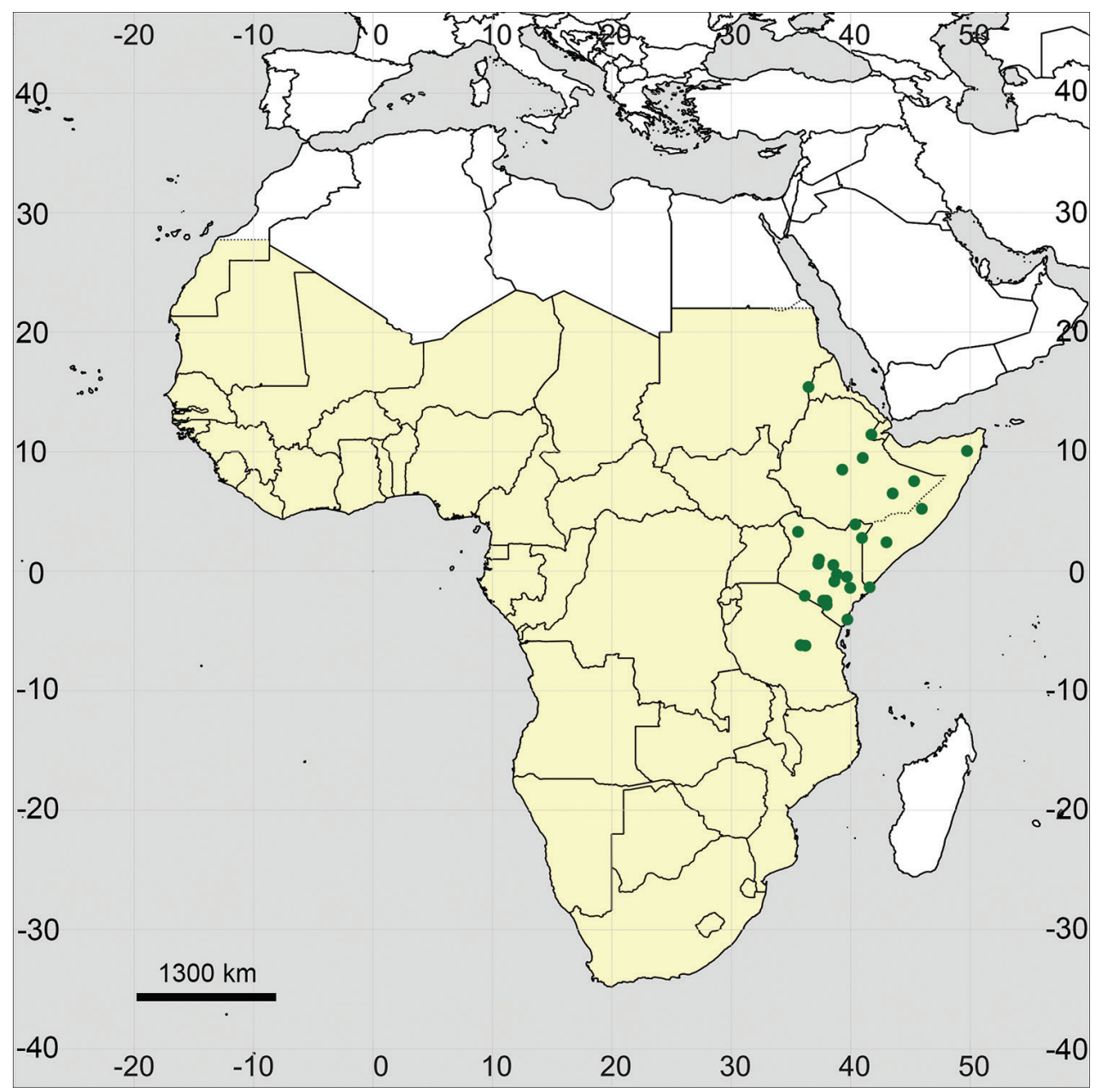

Figure 29. Distribution map of Glinus setiflorus in Sub-Saharan Africa (colored in yellow).

at senescence, adaxially white or creamy, in fruiting reaching $6.5-8.0 \mathrm{~mm}$ long, with a mucro $0.5-1.0 \mathrm{~mm}$ long. Stamens $10-15$, outer stamen series often sterile with filaments terminating with teeth; anthers (1.0)1.2-1.8 mm long (1.0-1.2 $\mathrm{mm}$ in plants from higher altitudes). Stylodia 3, 1.0-1.5 mm long (sometimes united in the lower half into a style). Seeds reddish or brown-red, 0.5-0.6 $\times 0.35-0.50 \mathrm{~mm}$, colliculate, without longitudinal ridges, aril hood clearly visible, ca. $0.25 \mathrm{~mm}$ long.

In the herbaria, $G$. zambesiacus was identified as $G$. lotoides, $G$. lotoides var. virens, $G$. lotoides $\times$ G. oppositifolius, and sometimes as $G$. bainesii. Glinus zambesiacus, $G$. oppositifolius, $G$. bainesii and $G$. hirtus are found in similar habitats. All character sets for each species are indicated in Table 5 . The new species can be easily differentiated from both $G$. oppositifolius and $G$. bainesii by indumentum consisting of stellate trichomes, while $G$. hirtus has much shorter perianth and fewer (up to 8) stamens. 
Glinus zambesiacus is related to African G. lotoides and G. setiflorus (Figs 1,2) and is easily differentiated from both by cylindrical anthocarp, not recessed leaf veins, length of anthers, number of stigmas, and seed colour (see Table 5).

Habitat. Sands, savannas or as a weed at altitudes up to $2200 \mathrm{~m}$ a.s.l. The plants growing in montane areas (DR Congo: Katanga province; Kenya; Tanzania) have much shorter pedicels (up to $6.0 \mathrm{~mm}$ long), and their flowers are subsessile. Such specimens were labelled in some herbaria as Glinus zambesiacus var. brevipedicellatus Sukhor. but this character seems to be variable in the specimens collected at lower altitudes.

Etymology. The new species is named after the territory of Zambezi river basin as its main distribution area.

Distribution (Fig. 31). Angola: [Cunene prov.] Mucope, 28 Nov 1963, C. Henriques 261 (BM, K, LISC032006);

Botswana: Ngamiland [North-West distr.], E of Cuando river, $3100 \mathrm{ft}$, Oct 1945, H.H. Curson 1052 (PRE0403680);

DR Congo: [Katanga prov.] Pweto, 952 m, 17 Apr 1926, W. Robyns 1999 (BR0000018269352, WAG0185132); Katanga prov., Mitwaba territory, Upemba, Sep 1948, G.F. de Witte 4304 (K, M, P04576569, WAG0185135 Katanga prov., Kasenga, 1 Nov 1948, A. Schmitz 2101 (BR0000018269376); Katanga prov., Kasenga, 920 m, 2 Jan 1960, J.-J. Symoens 7048 (BR0000018269680); Katanga prov., Pweto, 900 m, 18 May 1971, F. Malaisse 6767 (BR0000018269567); Katanga prov., Kantala river, 1480 m, Apr 1975, F. Malaisse 8724 (BR0000018269345, WAG0185133);

KenYa: [Nakuru county] Naivasha, 6000 ft, Aug 1934, A. Turner 6646 (K); [Nakuru county] Naivasha Lake, 6450 ft, Apr 1938, Team of Dept. Agric. Uganda 2351 (B101143600, BR0000018268751, K); nr Nairobi, 6000 ft, May 1943, G. Babault 5089 (FT0007102, K); [Trans-Nzoia county] Karara Dam, 13 Apr 1958, Y.E. Symes 339 (K); [Kajado county] Suswa, 6000 ft, 27 May 1963, P.E. Glover 3717 (BR0000017455992, K); [Nakuru county] Lake Naivasha, 22 Oct 1976, T. Hayes 160 (K); [Nakuru county] NW of Lake Naivasha, 1890 m, 15 May 1982, O.M. Mwangangi 2282 (K);

Namibia: [Oshana region] Amboland, Ongonga [Ondangwa], 8 Feb 1907, E. Liljeblad 80 (H1003175); [Kavango West region] Junction of Mpungu Omuramba and Okavango River between Tondoro and Lupala, 17 Dec 1955, B. de Winter 3974 (K, M); Namibia, Caprivi [Strip], Chobe river, 12 Nov 1970, G. Mahundu 431 (PRE0736547);

Zambia: [Western prov.] N of Kalabo, Barotse, Omboya stream, 11 Nov [without year], H.J.A. Rea 146 (K); [Central prov.] Luombwa, 16 Nov 1930, G.F. de Witte 37 (BR0000018269321, BR0000018269338); [Luapula prov.] Bangweulu Lake, May 1946, Bredo 1980 (BR0000018269529); [Eastern prov.] Petauke distr., Lunagwa river, 5 Sep 1947, P.J. Greenway \& J.P.M. Brenan 8052 (K); [Western prov.] Shangombo, 3400 ft, 9 Aug 1952, L.E. Codd 7463 (BM, K); [Copperbelt prov.] Kitwe, 27 Dec 1955, D.B. Fanshawe 2679 (BR0000018269574, K); [Southern prov.] Namwala, on Kalahari sand, waste ground nr gardens, 9 Jan 1957, E.A. Robinson 2101 (BR0000018269581, K); [Luapula prov.] Kawambwa, 10 Nov 1957, D.B. Fanshawe 3894 (K); Mongu, 11 Nov 1959, R.B. Drummond \& A.J. Cookson 6334 (E, K); [Luapula prov.] Fort Rosebery [Mansa], 8 Feb 1959, R. Watmough 231 (BM); Western Province, Bulozi plain, 22 Dec 1959, W. 


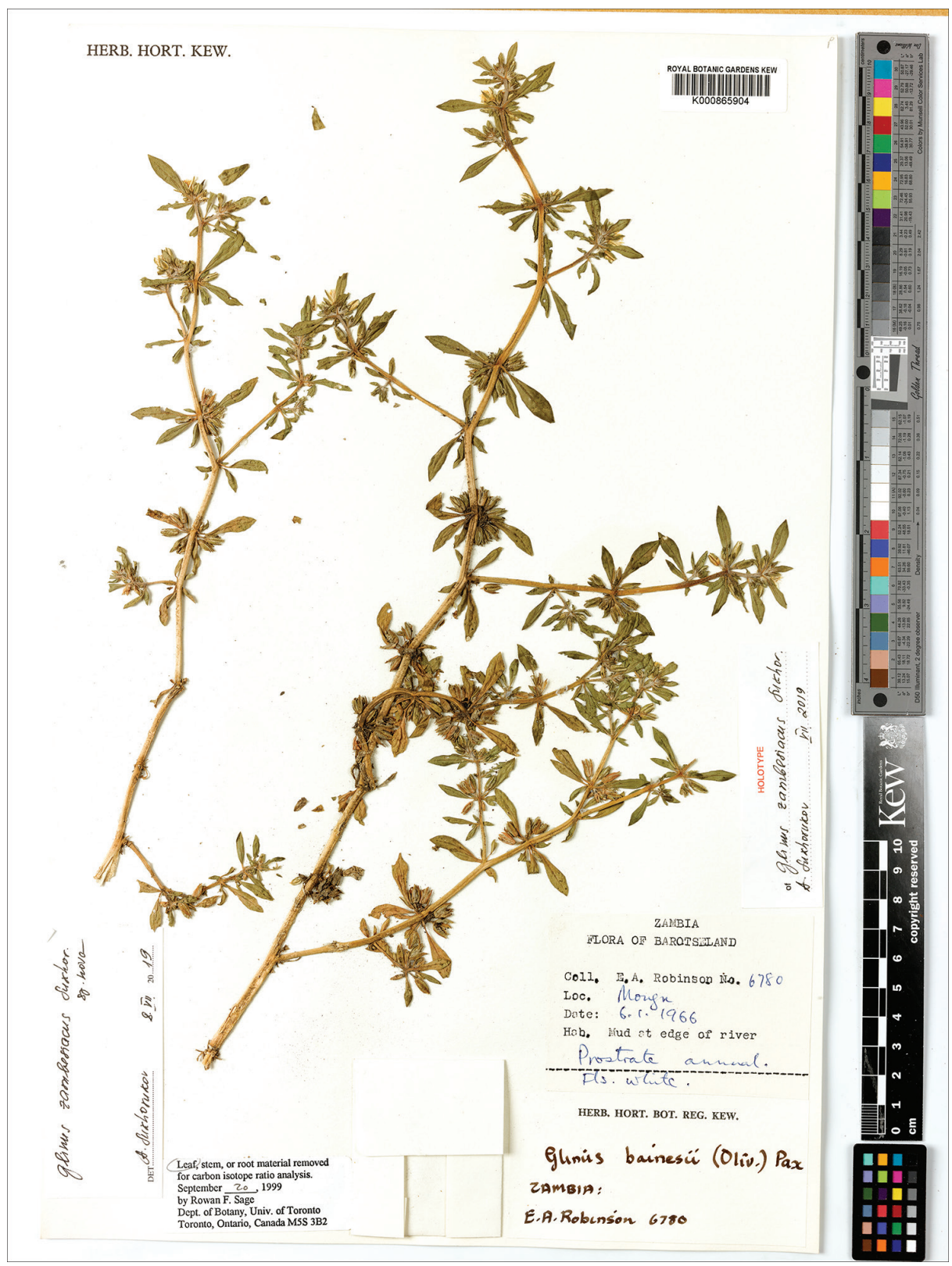

Figure 30. Holotype of Glinus zambesiacus Sukhor., sp. nov. (Zambia, Barotseland, [Western province] Mongu, mud at edge of river, 6 January 1966, Robinson 6780, K000865904). Copyright of the Board of Trustees of the Royal Botanic Gardens, Kew.

Gilges 748 (K); [Copperbelt prov.] Kaluba, 940 m, 24 Dec 1959, J.-J. Symoens 6822 (BR0000018269598); [Muchinga prov.] Mbesuma, 11 Oct 1960, E.A. Robinson 3950 (M); [Central prov.] Mwenda, 12 Dec 1960, J.-J. Symoens 7942 (BR0000018269383); 
[Northern prov.] Kasama, Chambesi river, 1200 m, 7 Apr 1961, H.M. Richards 15023 (K); [Northern prov.] Mofwe Dambo, 2850 ft, 30 Jul 1962, P.J. Tyler 148 (BM); [Lusaka prov.] Kafue, Kitwe, 11 Dec 1962, J.M. Mutimushi 237 (K); [Southern prov.] Namwala, 17 Dec 1962, H.J. van Rensburg 1105 (K); [Luapula prov.] Ndoba to Lubwe, Fourré station, 1140 m, 27 Jan1963, J.-J. Symoens 10023 (BR0000018269123, K); [Luapula prov.] W of Lake Bangweolo, $2 \mathrm{~km}$ N of Mwamfuli, 23 Dec 1964, J.J. Symoens 11202 (K); [Eastern province] Luangwa valley, Mfuwe, 26 Feb 1965, W.L. Astle 4121 (K); [Western province] Bulozi [Barotse] Plain nr Mongu, 14 Oct 1993, M. G. Bingham

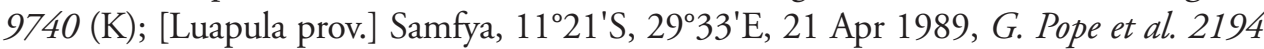
(BR0000018269093, K); [Lusaka prov.] Dembo Chisangwa, nr Kafwe [Kafue], 1140 m, 23 Nov 1998, B. Leteinturier et al. 439 (BR0000018269079 \& BR0000018269086);

TAnzania: [Mara region] Musoma distr., E of Naabi Hill, 10 May 1961, P.J. Greenway \& al. 10160 (K); [Ndutu region, nr Naabi Hills] Lamuta Hills, 5000 ft, 22 Jul 1962, J. Oteke 201 (K); [Arusha region] Ngorongoro Crater, 17 Jan 1965, J. Goddard 196 (WAG1103310);

Zimbавwe: [Matabeleland North prov.] Victoria Falls, Feb 1906, C.E.F. Allen 284 (K); Victoria Falls, 5 Jan 1955, E.A.Robinson 1058 (K); [Matabeleland North prov.] Sebungwe, Zambesi river, Binga, $1460 \mathrm{ft}$, common, 9 Nov 1958, J.B. Phipps 1414 (BR0000018269154, K).

Note. The images of B.T. Wursten taken in Mana Pools, Zimbabwe, and Kandahar Fishing site [nr Livingstone, Zambia] for the online "Flora Zambesiaca" (as G. lotoides var. virens) are $G$. zambesiacus.

General distribution. The species is only known from the countries listed above.

The most predictable records in the countries where no Glinus species were previously collected

Based on the distribution patterns of the species growing in Africa (Figs 15, 18, 21, 24, 26, 29, 31), the following species may occur in Equatorial Guinea, Lesotho and West Sahara.

Equatorial Guinea: Glinus hirtus, G. oppositifolius.

Lesotho: Glinus hirtus, G. lotoides, G. oppositifolius.

West Sahara: Glinus lotoides.

\section{Records excluded from Sub-Saharan Africa}

Glinus radiatus (Ruiz \& Pav.) Rohrb. in Martius, Fl. Bras. 14(2): 238 (1872).

$\equiv$ Mollugo radiata Ruiz \& Pav., Fl. Peruv. 1: 48 (1798).

三 Glinus cambessedesii Fenzl, Ann. Wiener Mus. Naturgesch. 1: 358 (1836), nom. illeg. Type: Chile, habitat in inundatis locis Conceptionis Chile ad Mochita et Carcamo terminum, H. Ruiz \& J.A. Pavón s.n. (MA?). 


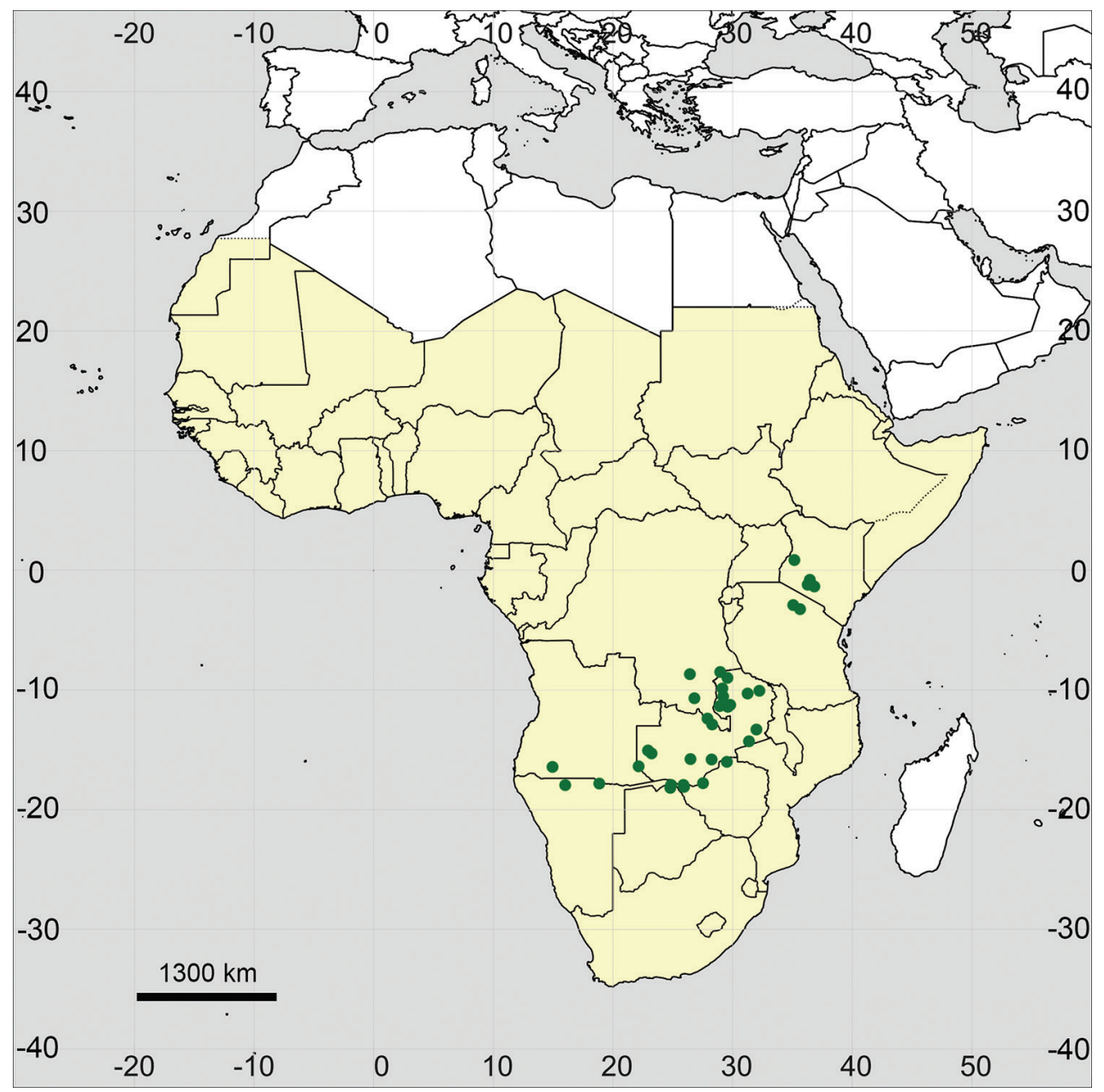

Figure 3 I. Distribution map of Glinus zambesiacus in Sub-Saharan Africa (colored in yellow).

= Mollugo glinoides Cambess. in Saint-Hilaire, Fl. Bras. Merid. 2: 171 (1830). Type: n.v. The protologue (Saint-Hilaire et al. 1829-1833) and the figure 109 show the plant with glabrous seeds. For this reason, Mollugo glinoides was synonymized with Glinus radiatus. Fenzl (1836) introduced $G$. cambessedesii as a substituting name for both Mollugo radiata and M. glinoides. = Mollugo araucana Phil., Anales Univ. Chile 85: 170 (1893). Type: n.v.

Note. The American Glinus radiatus was reported for Senegal and some other African countries (Central African Republic, Mali, Nigeria, and South Africa) as an alien species originating from tropical America (Berhaut 1979). It was later reported for Mali, Niger, Central African Republic, and repeatedly for Senegal by Boudet et al. (1986), for Benin by Akoegninou et al. (2006), for Guinea, Sierra Leone, Ghana, Ivory Coast by Lisowski (2009) and for Burkina Faso by Thiombiano et al. (2012) and Schmidt et 
al. (2017). We did not see any specimens of true G. radiatus from the whole of Africa, and almost all specimens identified as $G$. radiatus belong to the morphologically simi$\operatorname{lar} G$. hirtus. The differences between them are mentioned in the notes under $G$. hirtus. One of the specimens from Burkina Faso (Gnagna prov., Bogande, FR-0019665) identified as G. radiatus is indeed Zaleya pentandra (L.) C.Jeffrey (Aizoaceae).

\section{Species excluded from Glinus}

Glinus chrystallinus Forssk., Fl. Aegypt.-Arab.: 95 (1775).

$=$ Aizoon canariense $\mathrm{L}$.

Type material. Holotype: Egypt. Cairo (“Birket el-hadj”), [August 1762,] P.Forsskål Herb. Forsskål 544 (C10002319).

Note. The protologue (Forsskål 1775) was based on the only specimen indicated by Hepper and Friis (1994) as holotype. Hartmann (2001: 31) designated figure 14 in Forsskål (1776) as lectotype but this choice has no standing.

The locality information and the collection date are complemented from Hepper and Friis (1994).

\section{Glinus mozambicensis Spreng., Syst. Veg., ed. 16 [Sprengel] 2: 467 (1825).}

Glinus mucronatus (Klotzsch) in Peters, Naturw. Reise Mossambique 6 (Bot., 2): 570 (1864). Described from Mozambique.

= Corbichonia decumbens (Forssk.) Exell (see Sukhorukov and Kushunina 2015).

Type material. n.v. Probably described from Mozambique.

Note. No specimens were cited in the protologue (Sprengel 1825), and the description of G. mozambicensis is short and cannot be evaluated properly. According to Don (1834) and Endlicher and Fenzl (1839), it is a synonym of Gisekia pharnaceoides L. sensu lato [incl. G. africana Kuntze] (Gisekiaceae).

\section{Glinus trianthemoides Roth, Nov. P1. Spec.: 231 (1821).}

= Corbichonia decumbens (Forssk.) Exell (see Sukhorukov and Kushunina 2015).

Type material. Neotype (designated here): Hb. Wight in Wallich Cat. 1543 (addenda) (K001113401!).

Note. Roth (1821) is an account of plants collected by Benjamin Heyne in India. The corresponding herbarium specimens were donated to Roth, whose collection was purchased by the Berlin Botanical Garden (B) and largely destroyed together with the holdings of that Herbarium in 1943 (Hiepko 1987). Heyne made no records on the 
exact provenance of his specimens, and "India Orientalis" (the Indian Peninsula) is the only information published and known.

In the absence of any surviving original material, we used for neotypification one of the classical specimens assigned to the species by Fenzl (1836), who was the first to interpret the name.

Heyne (in Roth 1821) described G. trianthemoides as a plant with glabrous stems, obovate leaves with rounded tips, and lax, almost dichotomous inflorescences. Such characters are not found in any Glinus. Wight (Wight and Walker-Arnott 1834) accepted the placement of Roth's species in Glinus but doubted its taxonomic position in view of major morphological differences from the latter genus. Under the influence of that account, Fenzl (1836) established a separate genus for this taxon, Axonothechium Fenzl, still being uncertain about its precise taxonomic identity. Recent treatments (Gonçalves 1978; Sukhorukov and Kushunina 2015) placed Glinus trianthemoides into the synonymy of Corbichonia decumbens; this placement agrees with the material used by Fenzl and designated as neotype here.

\section{Conclusions}

Glinus is a monophyletic genus, presumably originating in tropical Africa, with predominant species diversity in Sub-Saharan Africa. Altogether, we accept six species for Sub-Saharan Africa, and none of them can be considered as locally endemic. Only $G$. bainesii and G. zambesiacus are restricted in their distribution to the southern and eastern parts of tropical Africa. A wide range of morphological characters can be used for the identification of Glinus species. In total, Glinus comprises 8-9 species (G. bainesii, G. hirtus, G. lotoides, G. oppositifolius, G. orygioides, G. radiatus, G. setiflorus, G. zambesiacus, and probably $G$. ononoides), and further research is needed to clarify the status of the American plants labelled as Glinus "lotoides".

\section{Acknowledgements}

We thank Andrew Budden (Royal Botanic Gardens Kew), Ranee Prakash and Jacek Wajer (Natural History Museum, London) for images of the specimens reproduced in the article. We are indebted to Sarah Bollendorff and Robert Vogt (BGBM), Erich van Wyk (PRE), Cornelia Klak (BOL), Geoffrey Fadeur and Pierre Meerts (BRLU), Demel Teketay (BACH), Mats Hjertson (UPS), Lorenzo Cecchi (FI), Lia Pignotti (FT) and Arno Wörz (STU) for the images of the specimens kept in indicated herbaria, as well as to the staff of the herbaria visited for their kind assistance. We are also thankful to Tony Dold (GRA) for checking the authentic material of Glinus bainesii, Pimwadee Pornpongrungrueng for sending the missing literature, Ridha El Mokni (Monastir University, Tunisia) for the images of living plants of Glinus lotoides and Hans-Joachim Esser (M) and Nicolas Fumeaux $(\mathrm{G})$ for a permission to obtain the leaf fragments for the molecular analysis. We are indebt- 
ed to Gian Pietro Giusso del Galdo and Pieter Winter for their valuable comments and suggestions to the first draft of the paper. The specimen K001394833 is supplied by RBG Kew from a collection made by CRRA under the DI project "The Darwin Initiative Research Exercise on Community Tree Seeds (DIRECTS)". The study design of APS, MK, MVN and MAM is in accordance with the scientific programmes 12-2-21 and AAAAA16-116021660106-0 of the Department of Higher Plants and Department of Plant Physiology, respectively (Lomonosov Moscow State University). The study of APS was also supported by the Tomsk State University competitiveness improvement programme.

\section{References}

Adamson RS (1961) The South African species of Aizoaceae. IX. Glinus. The Journal of South African Botany 27: 125-130.

Akoegninou A, van der Burg WJ, van der Maesen LJG [Eds] (2006) Flore analytique du Bénin. Backhuys Publishers, Cotonou, Wageningen.

Almeida MR (1998) Flora of Maharashtra, Vol. 2. St. Xavier's College, Mumbai.

APD [African Plant Database] (2019) Version 3.4.0. Conservatoire et Jardin botaniques de la Ville de Genève and South African National Biodiversity Institute, Pretoria. http://www. ville-ge.ch/musinfo/bd/cjb/africa/ [accessed 09 September 2019]

Armstrong KE, Stone GN, Nicholls JA, Valderrama E, Anderberg AA, Smedmark J, Gautier L, Naciri Y, Milne R, Richardson JE (2014) Patterns of diversification amongst tropical regions compared: A case study in Sapotaceae. Frontiers in Genetics 5: 1-13. https://doi. org/10.3389/fgene.2014.00362

Backer CA (1951) Aizoaceae [incl. Molluginaceae]. In: van Steenis CGGJ (Ed.) Flora Malesiana, Vol. 4. Noordhoof-Kolff, Jakarta, 267-275.

Barrelier J (1714a) Plantae per Galliam, Hispaniam et Italiam observatae, iconibus aeneis exibitae. S.Ganeau, Paris.

Barrelier J (1714b) Icones plantarum per Galliam, Hispaniam et Italiam observatar, ad vivum exhibitarum. S.Ganeau, Paris.

Barry JP, Celles JC (1991) Flore de Mauritanie, Vol. 1. Institut Superieur Scientifique de Nouakchott, Universite de Nice, Nouakchott, Nice.

Bentham G, Mueller F (1866) Flora Australiensis: A description of the plants of the Australian territory, Vol. 3. Reeve \& Co, London.

Berhaut J (1967) Flore de Sénégal, $2^{\text {nd }}$ ed. Éditions Clairafrique, Dakar.

Berhaut J (1979) Flore illustrée du Sénégal, Vol. 6. Gouvernement du Sénégal, Ministère du développement rural, Direction des eaux et forêts, Dakar.

Bhatia RC (1987) Imbibition and germination in the seeds of Glinus lotoides L. Acta Agrobotanica 40(1-2): 15-20. https://doi.org/10.5586/aa.1987.002

Blume CL (1826) Bijdragen tot de flora van Nederlandsch Indië. Ter Lands Drukkerij, Batavia [Jakarta]. https://doi.org/10.5962/bhl.title.6656

Boccone P (1674) Icones et descriptiones rariorum plantarum Siciliae, Melitae, Galliae, \& Italiae. Theatrum Sheldonianum, London. 
Boetsch JR (2002) The Aizoaceae and Molluginaceae of the Southeastern United States. Castanea 67(1): 42-53.

Bogle AL (1970) The genera of Molluginaceae and Aizoaceae in the southeastern United States. Journal of the Arnold Arboretum 51: 431-462. https://doi.org/10.5962/bhl.part.7046

Bouckaert R, Heled J, Kühnert D, Vaughan T, Wu CH, Xie D, Suchard MA, Rambaut A, Drummond AJ (2014) BEAST 2: A Software platform for Bayesian evolutionary analysis. PLoS Computational Biology 10(4): e1003537. https://doi.org/10.1371/journal.pcbi.1003537

Boudet G, Lebrun J-P, Demange R (1986) Catalogue des plantes vasculaires du Mali. CIRADIEMVT, Maisons-Alfort.

Boulos L (1999) Flora of Egypt, Vol. 1 (Azollaceae-Oxalidaceae). Al Hadara Publishing, Cairo.

Brundu G, Camarda I (2013) The Flora of Chad: A checklist and brief analysis. PhytoKeys 23(0): 1-18. https://doi.org/10.3897/phytokeys.23.4752

Burman NL (1768) Flora indica: cui accedit series zoophytorum indicorum, nec non prodromus florae capensis. Cornelius Haek, Johannes Schreuder, Leiden, Amsterdam. https://doi. org/10.5962/bhl.title.60581

Byalt VV, Korshunov MV (2020) New alien species of flowering plants to the flora of the Arabian Peninsula. Novitates Systematicae Plantarum Vascularium 51: 118-124. https://doi. org/10.31111/novitates/2020.51.118

Chevalier AJB (1938) Flore vivante de l'Afrique Occidentale Française (inclus Togo, Cameroun Nord, Oubangui-Chari-Tchad, Sahara français), Vol. 1. Muséum National d'Histoire Naturelle, Paris.

Christy CM (1998) Molluginaceae, Carpet-Weed family. Journal of the Arizona-Nevada Academy of Science 30(2): 112-114.

Clarke CB (1879) Ficoideae [Aizoaceae incl. Molluginaceae]. In: Hooker JD (Ed.) Flora of British India, Vol. 2. Reeve \& Co., London, 658-665.

Clarke K (1993) Non-parametric multivariate analyses of changes in community structure. Australian Journal of Ecology 18(1): 117-143. https://doi.org/10.1111/j.1442-9993.1993.tb00438.x

Clarke K, Gorley R (2006) PRIMER version 6: user manual/tutorial. PRIMER-E, Plymouth.

Clarke K, Warwick R (2001) Change in marine communities: An approach to statistical analysis and interpretation, $2^{\text {nd }}$ ed. PRIMER-E, Plymouth.

Clifton R (2003) Madagascar's plants: Checklist of the endemic (and indigenous) flowering plants. The Geraniaceae group, Dover.

Christin PA, Sage TL, Edwards EJ, Ogburn RM, Khoshravesh R, Sage RF (2011) Complex evolutionary transitions and the significance of C3-C4 intermediate forms of photosynthesis in Molluginaceae. Evolution 65(3): 643-660. https://doi.org/10.1111/j.15585646.2010.01168.x

Darbyshire I, Kordofani M, Farag I, Candiga R, Pickering H (2015) The plants of Sudan and South Sydan. An annotated checklist. Kew Publishing, London.

Darriba D, Taboada GL, Doallo R, Posada D (2012) jModelTest 2: More models, new heuristics and parallel computing. Nature Methods 9(8): 772-772. https://doi.org/10.1038/ nmeth.2109

Davis CC, Bell CD, Fritsch PW, Mathews S (2002) Phylogeny of Acridocarpus - Brachylophon (Malpighiaceae): Implications for Tertiary tropical floras and Afroasian biogeography. 
Evolution; International Journal of Organic Evolution 56(12): 2395-2405. https://doi. org/10.1111/j.0014-3820.2002.tb00165.x

de Candolle AP (1824) Prodromus systematis regni vegetabilis 1. Treuttel \& Würtz, Paris.

Dizionario delle scienze naturali (1842), Vol. 12 [without authors]. V. Batelli \& Co., Florence. Don G (1834) A general system of gardening and botany, Vol. 3. Gilbert \& Rivington, London. Doyle JJ, Doyle JS (1987) A rapid DNA isolation procedure for small quantities of fresh leaf tissue. Phytochemical Bulletin 19: 11-15.

Drège JF (1843) Standörter-Verzeichniss der von J.F. Drège in Südafrika gesammelten Pflanzen. Flora 26(2, Beigabe): 44-160.

du Petit-Thouars A (1806) Genera nova madagascariensia. Privately published, Paris.

Edgar RC (2004) MUSCLE: Multiple sequence alignment with high accuracy and high throughput. Nucleic Acids Research 32(5): 1792-1797. https://doi.org/10.1093/nar/ gkh340

Endlicher S (1840) Genera plantarum secundum ordines naturales disposita. F. Beck, Vienna. Endlicher S, Fenzl E (1839) Novarum stirpium decas I-X. Typis Sollingerianis, Vienna. https:// doi.org/10.5962/bhl.title.127663

Endress ME, Bittrich V (1993) Molluginaceae. In: Kubitzki K, Rohwer JG, Bittrich V (Eds) The families and genera of vascular plants. Vol. 2, Flowering plants: Dicotyledons; Magnoliid, Hamamelid and Caryophyllid families. Springer, Berlin, 419-426. https://doi. org/10.1007/978-3-662-02899-5_49

Ewart AJ, Petrie AHK (1926) Contributions to the flora no. 31. Additions to the flora of the Northern Territory and locality records. Proceedings of the Royal Society of Victoria, n.s. 38: $164-182$.

Fenzl E (1836) Monographie der Mollugineen und Steudelieen, zweier Unterabtheilungen der Familie der Portulacaceen. Nebst einem Zusatze zur Abhandlung über Acanthophyllum. Annalen des Wiener Museums für Naturgeschichte 1: 337-384.

Fenzl E (1840) Monographie der Mollugineen. Zweiter Artikel. Annalen des Wiener Mu.seums für Naturgeschichte 2: 243-310.

Figueiredo E, Smith GF [Eds] (2008) Plants of Angola [Strelitzia 22]. South African National Biodiversity Institute, Pretoria.

Forsskål P (1775) Flora Aegyptiaco-Arabica. Möller, Copenhagen.

Forsskål P (1776) Icones Rerum Naturalium. Möller, Copenhagen.

Friedrich HC (1966) Molluginaceae. In: Mexmüller H (Ed.) Prodromus einer Flora von Südwestafrika. Cramer, Munich, 1-21.

Gagnepain F (1918) Deux Gisekia et Mollugo noveaux d'Indo-Chine. Notulae Systematicae 3: 367-368. [Two species of Gisekia and Mollugo from Indochina]

Gautier L, Smith GF, Spichiger R, Klopper RR, Siebert SJ, Chatelain C (2006) Merging tropical and southern African flowering plant data: The African plant database project. In: Ghazanfar SA, Beentje HJ (Eds) Taxonomy and ecology of African plants, their conservation and sustainable use. Royal Botanic Gardens Kew, London, 629-642. [Proceedings of the $17^{\text {th }}$ AETFAT Congress, Addis Ababa, Ethiopia, 21 ${ }^{\text {st }}-26^{\text {th }}$ September 2003]

Geiger R (1961) Überarbeitete Neuausgabe von R. Geiger, Klima der Erde. Wandkarte 1: 16. [Mill.). Klett-Perthes, Gotha.] 
Germishuizen G, Meyer NL, Steenkamp Y, Keith M (2006) A checklist of South African plants. SABONET, Pretoria. [Southern African Botanical Diversity Network Report, no. 41]

Gernhard T (2008) The conditioned reconstructed process. Journal of Theoretical Biology 253(4): 769-778. https://doi.org/10.1016/j.jtbi.2008.04.005

Gilbert MG (1993a) Molluginaceae. In: Thulin M (Ed.) Flora of Somalia, Vol. 1. The Royal Botanic Gardens Kew, London, 106-111.

Gilbert MG (1993b) A review of Gisekia (Gisekiaceae). Kew Bulletin 48(2): 343-356. https:// doi.org/10.2307/4117942

Gilbert MG (2000) Molluginaceae. In: Edwards S, Tadesse M, Demissew S, Hedberg I (Eds) Flora of Ethiopia and Eritrea, Vol. 2, pt. 1. University of Uppsala, Addis Ababa, Uppsala, 229-237.

Gonçalves ML (1965) Subsídios para o conhesimento da flora de Angola - I. Garcia de Orta 13: 377-382.

Gonçalves ML (1970) Aizoaceae [s. 1., incl. Molluginaceae]. In: Exell AW, Fernandes A, Mendes EJ (Eds) Conspectus florae Angolensis, Vol. 4, Rosaceae-Alangiaceae. Oficinas gráficas da Imprimarte, Lisboa, 302-333.

Gonçalves ML (1978) Molluginaceae. In: Launert E (Ed.) Flora Zambesiaca, Vol. 4. Flora Zambesiaca Managing Committee, London, 522-548.

Gower JC (1971) A general coefficient of similarity and some its properties. Biometrics 27(4): 857-871. https://doi.org/10.2307/2528823

Grayum MH, Koutnik DL (1982) New records of vascular plants from The Santa Monica Mountians, California, and adjacent parts of Los Angeles and Ventura counties. Aliso 10(2): 313-320. https://doi.org/10.5642/aliso.19821002.10

Guindon S, Gascuel O (2003) A simple, fast and accurate method to estimate large phylogenies by maximum-likelihood. Systematic Biology 52(5): 696-704. https://doi. org/10.1080/10635150390235520

Gunn M, Codd LEW (1981) Botanical exploration of Southern Africa. CRC Press, Pretoria.

Hargreaves B (1995) The Aizoaceae sensu lato in Botswana. Botswana Note. and Records 27: 309-331.

Hartmann HEK (2001) Illustrated handbook of succulent plants: Aizoaceae F-Z. Springer, Berlin, Heidelberg, New York. https://doi.org/10.1007/978-3-642-56306-5

Harvey WH, Sonder OW (1860) Flora capensis: being a systematic description of the plants of the Cape colony, Caffraria, \& Port Natal (and neighbouring territories), Vol. 1. Hodges, Smith \& Co., Dublin \& Robertson, Capetown. https://doi.org/10.5962/bhl.title.821

Hassan NS, Hartmann HEK, Liede-Schumann S (2005) Conspectus of Aizoaceae, Gisekiaceae and Molluginaceae of Egypt and the Sudan. Feddes Repertorium 116(1-2): 1-42. https:// doi.org/10.1002/fedr.200410057

Hauman L (1949) Note sur quelques Aizoacées et sur un Chenopodium du Congo Belge. Bulletin du Jardin Botanique de l'État 19(4): 443-448. https://doi.org/10.2307/3666834

Hauman L (1951) Aizoaceae. In: Robyns W (Ed.) Flora du Congo Belge et du Ruanda-Urundi, Vol. 2. INEAC Publ., Brussels, 100-117.

Heath A, Heath R (2009) Field guide to the plants of Northern Botswana including the Okavango delta. Kew Botanical Gardens, London. 
Hedge IC, Lamond JM (1975) Molluginaceae. In: Rechinger KH (Ed.) Flora Iranica, Vol. 114. Akademische Druck- und Verlagsanstalt, Graz.

Heller D, Heyn CC (1994) Conspectus Florae Orientalis, Vol. 9. The Israel Academy of Sciences \& Humanities, Jerusalem.

Hepper FN, Friis I (1994) The plants of Pehr Forsskål's Flora Aegyptiaco-Arabica. Royal Botanic Gardens, Kew.

Hiepko P (1987) The collections of the Botanical Museum Berlin-Dahlem (B) and their history. Englera 7: 219-252.

Hiern WP (1898) Catalogue of the African plants collected by Dr. Friedrich Welwitsch in 18531861, Vol. 2. Printed by the order of the trustees, British Museum (Natural History), London. Hofmann U (1973) Morphologische Untersuchungen zur Umgrenzung und Gliederung der Aizoaceen (Centrospermen-Studien 6). Botanische Jahrbücher für Systematik, Pflanzengeschichte und Pflanzengeographie 93: 247-324.

Holstein N, Renner SS (2011) A dated phylogeny and collection records reveal repeated biome shifts in the African genus Coccinia (Cucurbitaceae). BMC Evolutionary Biology 11(1): e28. https://doi.org/10.1186/1471-2148-11-28

Hutchinson JL, Dalziel J (1927) Flora of West Tropical Africa, Vol. 1. Crown Agents, London. https://doi.org/10.2307/4107588

Jarvis C (2007) Order out of chaos. Linnean plant names and their types. The Linnean Society of London, The Natural History Museum, London.

Jeffrey C (1961) Aizoaceae [incl. Molluginaceae]. In: Hubbard CE, Milne-Redhead E (Eds) Flora of Tropical East Africa. Crown Agents, London, 1-35.

Just L (1879) Botanischer Jahresbericht, Vol. 7, part 2. Gebrueder Borntraeger, Berlin.

Klaassen E, Kwembeya E (2013) A checklist of Namibian indigenous and naturalised plants. National Botanical Research Institute, Windhoek.

Klopper RR, Chatelain C, Bänninger V, Habashi C, Steyn HM, de Wet BC, Arnold TH, Gautier L, Smith GF, Spichiger R (2006) Checklist of the flowering plants of Sub-Saharan Africa. An index of accepted names and synonyms. SABONET, Pretoria. [South African Botanical Diversity Network Report, no 42]

Köppen W (1936) Das geographische System der Klimate. In: Köppen CW, Geiger R (Eds) Handbuch der Klimatologie, Vol. 3. Borntraeger, Berlin.

Kurzweil H, Burgoyne P (2009) Closing bodies in the capsular fruits of Ruschioideae (Aizoaceae) - a review. Bothalia 39(1): 107-116. https://doi.org/10.4102/abc.v39i1.238

Lane MA, Keil DJ (1976) Glinus radiatus (Aizoaceae), chromosome count and range extension to Arizona. Madrono 23(8): 457-457. http://www.jstor.org/stable/41413989

Lebrun J-P, Stork AL (2003) Tropical African flowering plants. Ecology and distribution, Vol. 1 (Annonaceae-Balanitaceae). Conservatoire \& Jardin Botanique, Geneva.

Linnaeus C (1771) Car. a Linné Mantissa plantarum altera: Generum editionis VI. et Specierum editionis II. Impensis Direct. Laurentii Salvii, Stockholm.

Lisowski S (2009) Flore (Angiospermes) de la République de Guinée [Flora (Angiosperms) of the Republic of Guinea], pt. 1. Scripta Botanica Belgica 41: 1-517.

Löve A (1967) IOPB chromosome number reports. Taxon 16(5): 445-461. https://doi. org/10.1002/j.1996-8175.1967.tb02050.x 
Lu D, Hartmann HEK (2003) Molluginaceae. In: Wu Z, Raven PH (Eds) Flora of China, Vol. 5. Ulmaceae-Basellaceae. Science Press, Missouri Botanical Garden Press, Beijing, St. Louis, 437-439.

Maire R (1962) Flore de l'Afrique du Nord, Vol. 8. Paul Lechevalier, Paris.

Mapaura A, Timberlake J [Eds] (2004) A checklist of Zimbabwean vascular plants [Southern African Botanical Diversity Network Report No. 33]. SABONET, Pretoria, Harare.

Matzke NJ (2013) Probabilistic historical biogeography: New models for founder event speciation, imperfect detection, and fossils allow improved accuracy and model testing. Frontiers of Biogeography 5(4): 242-248. https://doi.org/10.21425/F55419694

Matzke NJ (2014) Model selection in historical biogeography reveals that founder event speciation is a crucial process in island clades. Systematic Biology 63(6): 951-970. https://doi. org/10.1093/sysbio/syu056

Merrill ED (1921) A review of the new species of plants proposed by N.L. Burman in his Flora Indica. Philippine Journal of Science 19: 329-388.

Miller AG (1996) Aizoaceae [s.l.]. In: Miller AG, Cope TA (Eds) Flora of the Arabian Peninsula and Socotra, Vol. 1. University Press, Edinburgh, 155-168.

Miller MA, Pfeiffer W, Schwartz T (2010) Creating the CIPRES science gateway for inference of large phylogenetic trees. Gateway Computing Environments Workshop (GCE), New Orleans, Los Angeles, 1-8. https://doi.org/10.1109/GCE.2010.5676129

Morton CV (1970) Taxonomic notes on ferns, IV. American Fern Journal 60(3): 103-106. https://doi.org/10.2307/1546087

Müller K (1908) Beiträge zur Systematik der Aizoaceen. Botanische Jahrbücher für Systematik, Pflanzengeschichte und Pflanzengeographie 42. Beiblatt 97: 54-94.

Müller J, Müller K, Neinhuis C, Quandt D (2010) PhyDE: Phylogenetic Data Editor v 0.9971. http://phyde.de

Narayana HS, Lodha BC (1972) Embryology of Glinus lotoides Linn. Proceedings of the Indian Academy of Sciences. Section B, Biological Sciences 75: 77-85.

Oliver D (1871) Flora of Tropical Africa, Vol. 2 (Leguminosae to Ficoideae). Reeve \& Co, London.

Paradis G (1993) Glinus lotoides L. (Molluginaceae), espèce nouvelle pour la flore de Corse et de France. Localisation. Synécologie. Acta Botanica Gallica 140(7): 819-826. https://doi. org/10.1080/12538078.1993.10515680

Paradis E, Claude J, Strimmer K (2004) APE: Analyses of Phylogenetics and Evolution in R language. Bioinformatics (Oxford, England) 20(2): 289-290. https://doi.org/10.1093/ bioinformatics/btg 412

Parolin P (2006) Ombrohydrochory: Rain-operated seed dispersal in plants - with special regard to jet-action dispersal in Aizoaceae. Flora 20(7): 511-518. https://doi.org/10.1016/j. flora.2005.11.003

Passarge S (1904) Die Kalahari. Versuch einer physisch-geographischen Darstellung der Sandfelder des südafrikanischen Beckens. Reimer Verlag, Berlin.

Perveen A, Qaiser M (2000) Pollen flora of Pakistan. XX. Molluginaceae. Turkish Journal of Botany 24: 25-28. 
Phiri PSM (2005) A checklist of Zambian vascular plants [Southern African Botanical Diversity Network Report No. 32]. SABONET, Pretoria.

Phuphathanaphong L (2005) Molluginaceae. In: Santisuk T, Larsen K (Eds) Flora of Thailand, Vol. 9, part 1. The Forest Herbarium \& National Park, Wildlife \& Conservation Department, Bangkok, 42-49.

Pitot A (1965) A partir des espèces ouest-africaines considerations sur les genres 'Mollugo' et 'Glinus'. Webbia 19: 752-808.

Plukenet L (1705) Amaltheum botanicum. Sumptibus auctoris, London.

Rambaut A, Suchard MA, Xie D, Drummond AJ (2014) Tracer v1.6. Program distributed by the author. http://beast.bio.ed.ac.uk/Tracer

Retief E, Meyer NL (2017) Plants of the Free State. Inventory and identification guide. SANBI, Pretoria. [Strelitzia 38]

Roth AG (1821) Novae plantarum species praesertim Indiae Orientalis ex collectione Doct. Benj. Heynii, cum descriptionibus et observationibus. H.Vooler, Halberstad. https://doi. org/10.5962/bhl.title.10723

Saint-Hilaire A, Jussieu A, Cambessedes J (1829-1833) Flora Brasiliae Meridionalis, Vol. 2. A. Belin, Paris.

Schmidt M, Zizka A, Traoré S, Ataholo M, Chatelain C, Daget P, Dressler S, Hahn K, Kirchmair I, Krohmer J, Mbayngone E, Müller JV, Nacoulma B, Ouédraogo A, Ouédraogo O, Sambaré O, Schumann K, Wieringa JJ, Zizka G, Thiombiano A (2017) Diversity, distribution and preliminary conservation status of the flora of Burkina Faso. Phytotaxa 304(1): 1-215. https://doi.org/10.11646/phytotaxa.304.1.1

Setshogo MP (2005) Preliminary checklist of the plants of Botswana [Southern African Botanical Diversity Network Report No. 37]. SABONET, Pretoria \& Gaborone.

Short PS (2002) A new species of Glinus L. (Molluginaceae) from the Northern territory, Australia. Telopea 9(4): 761-763. https://doi.org/10.7751/telopea20024014

Short PS (2011) Molluginaceae. In: Short PS, Cowie ID (Eds) Flora of the Darwin Region (Northern Territory), Vol. 1. Herbarium, Department of Natural Resources, Environment, the Arts and Sport, Palmerston, 1-7.

Sita P, Moutsambote J-M (1988) Catalogue des plantes vasculaires du Congo. Institut Français de Recherche Cintifique por le Developpment, Centre de Brazzaville, Brazzaville.

Sosef MSM, Wieringa JJ, Jongkind CCH, Achoundong G, Azizet Issembé Y, Bedigian D, van den Berg RG, Breteler FJ, Cheek M, Degreef J, Faden RB, Goldblatt P, van der Maesen LJG, Ngok Banak L, Niangadouma R, Nzabi T, Nziengui B, Gogers ZS, Stévart T, van Valkenburg JLCH, Walters G, de Wilde JJFE (2006) Checklist of Gabonese vascular plants. National Botanic Garden of Belgium, Meise.

Sprengel K (1825) Systema vegetabilium, ed. 16, Vol. 2. Sumtibus Librariae Dieterichianae, Göttingen.

Stamatakis A (2014) RAxML Version 8: A tool for phylogenetic analysis and post-analysis of large phylogenies. Bioinformatics (Oxford, England) 30(9): 1312-1313. https://doi. org/10.1093/bioinformatics/btu033

Stöver BC, Müller KF (2010) TreeGraph 2: Combining and visualizing evidence from different phylogenetic analyses. BMC Bioinformatics 11(1): e7. https://doi.org/10.1186/1471-2105-11-7 
Sukhorukov AP, Kushunina M (2015) Taxonomy and chorology of Corbichonia (Lophiocarpaceae s.l.) with further description of a new species from southern Africa. Phytotaxa 218(3): 227-240. https://doi.org/10.11646/phytotaxa.218.3.2

Sukhorukov AP, Kushunina M (2017) Taxonomic significance of seed morphology in the genus Mollugo s.l. Israel Journal of Plant Sciences 64(1-2): 31-47. https://doi.org/10.1080/079 29978.2016.1249137

Sukhorukov AP, Zhang M-L, Kushunina M, Nilova MV, Krinitsina A, Zaika MA, Mazei Y (2018) Seed characters in Molluginaceae (Caryophyllales): Implications for taxonomy and evolution. Botanical Journal of the Linnean Society 187(2): 167-208. https://doi. org/10.1093/botlinnean/boy021

Sukhorukov AP, Sennikov AN, Nilova MV, Mazei Y, Kushunina M, Marchioretto MS, Hanáček P (2019) Evolutionary relationships and taxonomy of Microtea (Microteaceae), a basal lineage in the core Caryophyllales. PhytoKeys 115: 1-50. https://doi.org/10.3897/ phytokeys.114.29041

Sulakshana M, Raju AJS (2018) Floral biology and pollination of carpet weeds, Glinus lotoides L. and Glinus oppositifolius (L.) Aug.DC. Anales de Biología 40(40): 103-114. https://doi. org/10.6018/analesbio.40.12

Swofford DL (2002) PAUP* Phylogenetic Analysis Using Parsimony (*and other methods). Version 4. Sinauer Associates, Sunderland.

Täckholm V, Boulos L (1972) Supplementary notes to Student's flora of Egypt. Publication of the Cairo University Herbarium 5: 3-135.

Takhtajan AL (1986) Floristic regions of the World. University of California, Berkeley.

Teshome S, Feyissa T (2015) Micropropagation of Glinus lotoides L.: An endangered medicinal plant. Advances in Life Sciences \& Technology 34: 32-41.

Thieret JW (1966) Seeds of some United States Phytolaccaceae and Aizoaceae. Sida 2: 352-360.

Thiombiano A, Schmidt M, Dressler S, Ouédraogo A, Hahn K, Zizka G (2012) Catalogue des plantes vasculaires du Burkina Faso. Boissiera 65: 1-405. [Catalogue of the vascular plants of Burkina Faso]

Thulin M, Moore AJ, El-Seedi H, Larsson A, Christin P-A, Edwards EJ (2016) Phylogeny and generic delimitation in Molluginaceae, new pigment data in Caryophyllales, and the new family Corbichoniaceae. Taxon 65(4): 775-793. https://doi.org/10.12705/654.6

Thunberg CP (1794) Prodromus plantarum Capensium, quas in promontorio Bonae Spei Africes, annis 1772-1775, collegit Carol Peter Thunberg. Edman, Uppsala. https://doi. org/10.5962/bhl.title.84

Tosso F, Hardy OJ, Doucet J-L, Dainou K, Kaymak E, Migliore J (2017) Evolution in the Amphi-Atlantic tropical genus Guibourtia (Fabaceae, Detarioideae), combining NGS phylogeny and morphology. Molecular Phylogenetics and Evolution 120: 83-93. https://doi. org/10.1016/j.ympev.2017.11.026

Townsend CC (2016) Molluginaceae. In: Ghazanfar SA, Edmondson JR (Eds) Flora of Iraq, Vol. 5(1). Bell \& Bain Ltd., Glasgow, 3-5.

Trimen H (1894) A hand-book to the flora of Ceylon, Vol. 2. Dulao \& Co, London.

Turland NJ, Wiersema JH, Barrie FR, Greuter W, Hawksworth DL, Herendeen PS, Knapp S, Kusber W-H, Li D-Z, Marhold K, May TW, McNeill J, Monro AM, Prado J, Price MJ, 
Smith GF [Eds] (2018) International Code of Nomenclature for algae, fungi, and plants (Shenzhen Code) adopted by the Nineteenth International Botanical Congress Shenzhen, China, July 2017. Koeltz Botanical Books, Glashütten. [Regnum Vegetabile 159]

Tutin TG, Burges NA, Chater AO, Edmondson JR, Heywood VH, Moore DM, Valentine DH, Walters SM, Webb DA [Eds] (1993) Flora Europaea, $2^{\text {nd }}$ ed., Vol. 1. Cambridge University Press, Cambridge.

van Steenis CGGJ (1966) Miscellaneous botanical notes XV. Blumea 13(1): 167-169.

Veranso-Libalah MC, Kadereit G, Stone RD, Couvreur TLP (2018) Multiple shifts to open habitats in Melastomateae (Melastomataceae) congruent with the increase of African Neogene climatic aridity. Journal of Biogeography 45(6): 1420-1431. https://doi.org/10.1111/ jbi. 13210

Vigosa Mercado JL (2015) Molluginaceae. In: Jiménez J, Fonseca RM, Martínez M (Eds) Flora de Guerrero, Vol. 65 (Cytinaceae-Molluginaceae). Universidad Nacional Autónoma de México, Mexico, 13-26.

Vincent MA (2003) Molluginaceae. In: Flora of North America Editorial Committee (Eds) Flora of North America, North of Mexico, Vol. 4. Oxford University Press, New York, Oxford, 509-512.

White TJ, Bruns T, Lee S, Taylor J (1990) Amplification and direct sequencing of fungal ribosomal RNA genes for phylogenetics. In: Innis MA, Gelfand DH, Snisky JJ, White TJ (Eds) PCR Protocols: A guide to methods and applications. Academic Press, San Diego, 315-322. http://dx.doi.org/10.1016/b978-0-12-372180-8.50042-1

Wight R, Walker-Arnott GA (1834) Prodromus florae peninsulae Indiae orientalis, Vol. 1. Parbury, Allen \& Co., London.

Yao G, Jin J-J, Li H-T, Yang J-B, Mandala VS, Croley M, Mostow R, Douglas NA, Chase MW, Christenhusz MJM, Soltis DE, Soltis PS, Smith SA, Brockington SF, Moore MJ, Yi T-S, Li D-Z (2019) Plastid phylogenomic insights into the evolution of Caryophyllales. Molecular Phylogenetics and Evolution 134: 74-86. https://doi.org/10.1016/j.ympev.2018.12.023

Zohary M (1966) Flora Palaestina, Vol. 1. The Israel Academy of Sciences and Humanities, Jerusalem. 